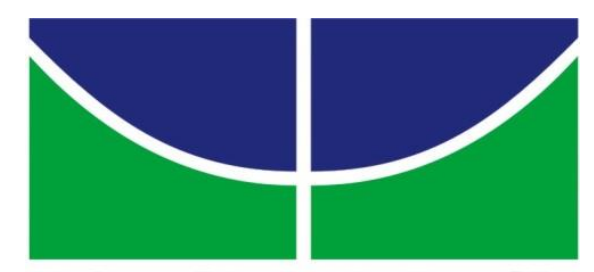

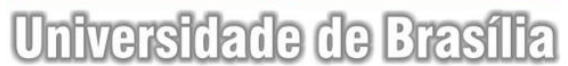

FACULDADE DE EDUCAÇÃO

PROGRAMA DE PÓS-GRADUAÇÃO EM EDUCAÇÃo

\title{
PROGRAMA MULHERES MIL: UMA OPORTUNIDADE DE REINSERÇ̃̃O SOCIAL CIDADÃ ÀS REEDUCANDAS DA PENITENCIÁRIA FEMININA DO DISTRITO FEDERAL
}

CRISONÉIA NONATA DE BRITO GOMES

BRASÍLIA-DF

DEZEMBRO DE 2015 


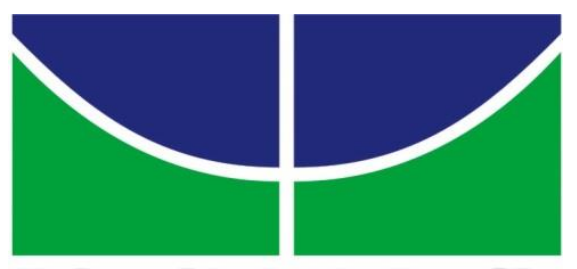

Onfurersidadio dio Brasilla

FACULDADE DE EDUCAÇÃO

PROGRAMA DE PÓS-GRADUAÇÃO EM EDUCAÇÃO

\section{PROGRAMA MULHERES MIL: UMA OPORTUNIDADE DE REINSERÇÃO SOCIAL CIDADÃ ÀS REEDUCANDAS DA PENITENCIÁRIA FEMININẢ DO DISTRITO FEDERAL}

\section{CRISONÉIA NONATA DE BRITO GOMES}

Dissertação de Mestrado apresentada ao Programa de Pós-Graduação em Educação da Faculdade de Educação da Universidade de Brasília/UnB, como parte dos requisitos para obtenção do título de Mestre em Educação, área de concentração: Políticas Públicas e Gestão em Educação Profissional e Tecnológica.

Orientador: Professor Dr. Bernardo Kipnis 
Ficha catalográfica elaborada automaticamente, com os dados fornecidos pelo(a) autor(a)

de Brito Gomea, Crimoneia Nonata

PROGRAMA MULHERES MIL: UMA OPORTUNIDADE DB REINSERÇ̄̄o SOCIAL CIDADẌ Às REEDUCANDAS DA PENITENCIÁRIA FEMININA DO DISTRITO FEDERAL / Criaoneia Nonata de Brito Gomea; orientador Bernardo Kipnia; co-orientador Maria Crietina Madeira da Silva. -- Brasilia, 2015.

$128 \mathrm{p}$.

Dimaertaç̄̃o (Meatrado - Meatrado en Bducaç̄̄o) -Univeraidade de Branflia, 2015.

1. Bducação Profienional. 2. Politicas Páblican e Gentão da Bducacão Profimsional. 3. Politican Páblica para Mulherea Privadan de Liberdade. 4. Siatem Priaional. 5. Programa Mulherea Mil. I. Kipnia, Bernardo, orient. II. Madeira da Silva, Maria Criatina , co-orient. III. Titulo. 


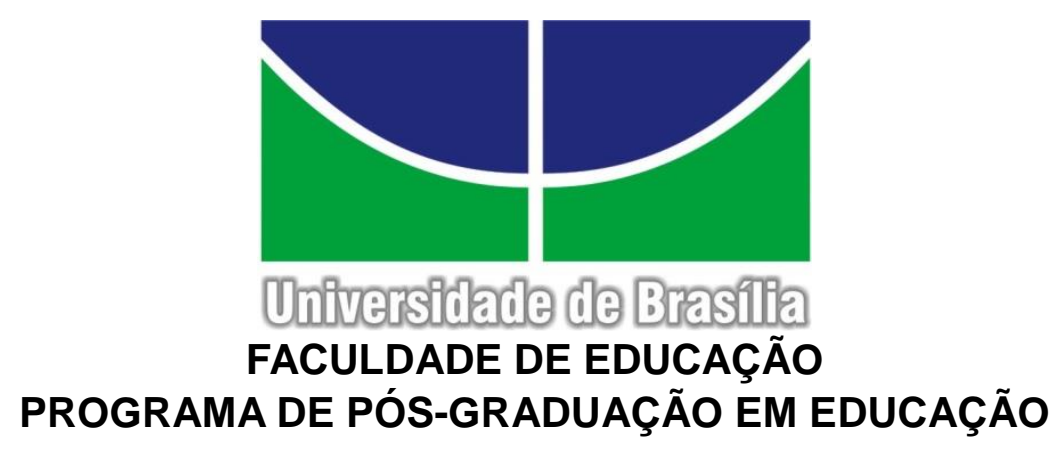

\author{
CRISONÉIA NONATA DE BRITO GOMES
}

PROGRAMA MULHERES MIL: UMA OPORTUNIDADE DE REINSERÇÃO SOCIAL CIDADÃ ÀS REEDUCANDAS DA PENITENCIÁRIA FEMININA DO DISTRITO FEDERAL.

\title{
BANCA EXAMINADORA
}

\section{Prof. Dr. Bernardo Kipnis (Orientador) \\ Faculdade de Educação - FE/UnB}

Prof. a Dra. Maria da Conceição da Silva Freitas (Membro Interno)

Faculdade de Educação - FE/UnB

\section{Prof. a. Dra. Maria Cristina Madeira da Silva (Membro Externo)} Instituto Federal de Brasília - IFB 
Ao Deus Supremo Pai, a Jesus Cristo, Cavaleiro do Céu, Grande Jeová, ao seu Santo Espírito que me fortaleceu e nunca me desamparou e me fez vencedora em mais esta batalha. A Ele toda honra e toda a glória! 


\section{AGRADECIMENTOS}

Em tudo dai graças! Agradeço a Deus por haver me capacitado e fortalecido no decorrer de minha existência, sobretudo nesta batalha, e que fez com que as portas fossem abertas, tudo no tempo certo e na hora certa, conforme a Sua Santa vontade.

A minha família, em especial aos meus amados filhos, netos, genro e nora, por terem suportado minhas ausências, irritações, crises de choro e intransigências, pois foram eles que me fortaleceram nesta caminhada e foi por eles: Cristiano, Cricia, Crístofer, Isabelle, Túlio e Enrico, minha herança! Por eles empreendi todos os esforços possíveis para chegar até aqui.

Às Reeducandas da Penitenciária Agrícola do Monte Cristo penitenciária feminina de Roraima, pelo carinho, pela confiança que me foi depositada, vocês me inspiraram do começo ao fim, especialmente à querida diretora Sandra Araújo. O mundo agora conhecerá o trabalho desenvolvido pelo Instituto Federal de Roraima na PA. Prometi e cumpri!

Às Reeducandas, da Colméia - Presídio Feminino do Distrito Federal, por suas preciosas contribuições, pelos momentos vivenciados e por demonstrarem com suas respostas, que creem na possibilidade da mudança por meio da Educação.

Agradeço àqueles que sempre acreditaram em meu potencial e para isso contribuíram dedicando seu tempo, amor, orientação e carinho. A vocês: Jane da Silva Amorim, (mi madre intelectual), Érika Lima, Daniela Veiga, Lusérgio Sales, Maria do Socorro Paiva, Adeline Araújo Carneiro, Maria Cristina Madeira da Silva, (Irmã do coração e orientadora), Aléssio Trindade, Carlos Ávila, e Lúcia de Fátima Oliveira, (Amada irmã em Cristo).

Aos queridos professores Olgamir Francisco Carvalho e Remi Castione, por suas militâncias na Faculdade de Educação e nos fazerem acreditar no poder transformador da Educação Profissional.

Aos colegas do MPROF, pelos momentos que juntos passamos, pelas contribuições, as alegrias e angústias compartilhadas, pela união que nos fortaleceu nesses dois anos de luta. Estou chorando de saudades!

Ao meu orientador, que, com sua imensa paciência, sapiência e dedicação, conseguiu lapidar as minhas ideias. Obrigado professor Dr. Bernardo Kipnis. 
"A prisão é o único lugar onde o poder se manifesta sem nenhuma necessidade de se mascarar."

(Michel Foucault)

“(...) não podendo tudo, a prática educacional pode alguma coisa. "

(Paulo Freire) 


\section{RESUMO}

Com o propósito de reparar as desigualdades das relações de gênero, no Brasil têm sido implementadas políticas públicas que visam à inclusão, à equidade de gênero, à emancipação e ao empoderamento das mulheres pelo acesso à educação e ao mundo do trabalho. Em meio a essas políticas, destacase o Programa Nacional Mulheres Mil. Nesse sentido o presente trabalho se propõe a estudar a reinserção social cidadã das reeducandas do presídio feminino do Distrito Federal por meio do Programa Mulheres Mil. Esse programa é uma política pública inclusiva que visa proporcionar a mulheres em condição de vulnerabilidade social o acesso à educação, à qualificação, ao emprego e à geração de renda, por meio de uma formação profissional e cidadã. O Objetivo geral do trabalho é compreender as contribuições do programa na vida das reeducandas, egressas dos cursos de Estética Feminina e Recepcionista, que foram qualificadas e formadas pelo IFB-Campus Gama, entre os anos de 2013 a 2014. O estudo em tela parte do histórico das desigualdades vividas pela mulher na sociedade brasileira, enfatizando as dificuldades de acesso à educação e ao ingresso no mercado de trabalho. Enfatiza a situação da mulher privada de liberdade e a educação nos presídios. Nos depoimentos das reeducandas egressas buscou-se saber o que o acesso à formação profissional agregou a suas vidas, que expectativas foram geradas quanto ao incentivo à elevação da escolaridade, e as possibilidades de inserção produtiva e mobilidade no mundo do trabalho, como objetiva o Mulheres Mil. Os resultados desta pesquisa revelaram que as reeducandas egressas, tiveram sua autoestima elevada, melhoraram seus relacionamentos interpessoais e, algumas delas, apresentaram modificações nos seus itinerários formativos. Contudo, mostram que os dois cursos ofertados não corresponderam às expectativas quanto à reinserção no mercado de trabalho e nem a possibilidade de geração de renda ainda em reclusão. Com base na análise da pesquisa realizada, propôs-se um produto técnico o qual consiste em um modelo de programa sustentável específico para as mulheres encarceradas do Sistema Prisional do DF, pois entende-se que o cárcere é um lugar que requer a construção de um novo itinerário de vida que proporcione a geração de renda às reeducandas durante o período que ainda estejam reclusas, partindo dos aspectos que fomentaram a 
origem e a institucionalização do Programa Mulheres Mil - Educação, Cidadania e Desenvolvimento Sustentável.

Palavras-chave: Programa Mulheres Mil. Educação. Mulheres Privadas de Liberdade. Políticas Públicas. Reinserção Profissional de Mulheres Encarceradas. 


\begin{abstract}
In order to compensate inequalities in gender relations, the Brazilian government has implemented public policies aiming at social inclusion, gender equality, political emancipation, and empowerment of women by improving their access to education and the labour market. Among such policies, the "Mulheres Mil" National Program stands out. As such, this study focuses on the social reinsertion of female inmates at the Prison of the Federal District (DF), Brazil, by means of the "Mulheres Mil" Program. The program is an inclusive policy that aims at promoting employment and generation of income opportunities, by offering professional qualification and citizenship education. The overall objective is to understand how the program contributes to the lives of the female inmates, after their having taken a Cosmetology or Receptionist Course at the Brazilian Federal Institute (IFB), at the Gama Campus, from 2013 to 2014. This study considers the history of female gender inequality in Brazilian society, emphasising the difficulties for women to access education and the labour market, but it specifically focuses on women who have been deprived of freedom and education in prison. In their testimonials, we tried to identify how professional qualification changed their lives and what expectations and opportunities of employment were created, as intended by the Mulheres Mil Program. Within a qualitative research framework, we used interviews, a focus group and questionnaires that revealed the boosting of self-esteem levels, improvement of interpersonal relationships and, in some cases, significant change in training itineraries. However, both of the offered courses did not meet expectations concerning employment and the generation of income opportunities. Upon analysing the research, a sustainable "Mulheres Mil" Program model resulted as a technical by-product, applicable specifically to imprisoned women in the prison system of the Federal District (DF). It is our understanding that prison is a place that requires a new lifestyle and itinerary that enables the generation of income by inmates while carrying out their sentences, based upon the concepts that originated and institutionalized the "Mulheres Mil" Program: education, citizenship and sustainable development.
\end{abstract}

Key-words: "Mulheres Mil" Program. Education. Imprisoned Women. Public Policies. Professional Reintegration of Imprisoned Women. 


\section{LISTA DE SIGLAS}

$\mathrm{Al} / \mathrm{GM}$

ABC/MRE

ACCC

ATP

CEFET

CIDA

CNAE

CNDM

CODEPLAN

CONIF

DEPEN

IFB

IBGE

INFOPEN/MULHERES

IPEA

LEP

MEC

MJ

NUEN

OCB/SESCOOP

OEA

OIT

ONU

PA

PEEASP

PFDF

PMM

PNAD

PNPM

PRONATEC

PROUNI

RAIS

REDENET
Assessoria Internacional do Gabinete do Ministro

Agência Brasileira de Cooperação

Associação dos Colleges Comunitários Canadenses

Ala de Tratamento Psiquiátrico

Centro Federal de Educação Tecnológica

Agência Canadense para o desenvolvimento Internacional

Cadastro Nacional de Atividades Econômicas

Conselho Nacional dos Direitos da Mulher

Companhia do Desenvolvimento do Planalto Central

Conselho Nacional das Instituições da Rede Federal de Educação Profissional, Científica e Tecnológica Departamento Penitenciário Nacional

Instituto Federal de Educação, Ciência e Tecnologia de Brasília

Instituto Brasileiro de Geografia e Estatística

Informações Penitenciárias de Mulheres

Instituto de Pesquisa Econômica Aplicada

Lei de Execução Penal

Ministério da Educação e Cultura

Ministério da Justiça

Núcleo de Ensino do Sistema Prisional

Organização das Cooperativas Brasileiras

Organização dos Estados Americanos

Organização Internacional do Trabalho

Organização das Nações Unidas

Penitenciária Agrícola

Plano Estratégico de Educação no Âmbito do Sistema

Prisional

Presidio Feminino do Distrito Federal

Programa Mulheres Mil

Pesquisa Nacional por Amostra de Domicílios

Plano Nacional de Políticas para as Mulheres

Programa Nacional de Acesso ao Ensino Técnico e

Emprego

Programa Universidade para Todos

Relação Anual de Informações Sociais

Rede Norte e Nordeste de Educação Tecnológica 
RIDE

SECADI

SENAC

SENAR

SESI

SESIPE

SETEC

SINE

SPM

UNIFEM

VEP
Região de Desenvolvimento Integrado do Distrito Federal

Secretaria de Educação Continuada, Alfabetização e Diversidade

Serviço Nacional de Aprendizagem Comercial

Serviço Nacional de Aprendizagem Rural

Serviço Social da Indústria

Secretaria do Sistema Penitenciário

Secretaria de Educação Profissional e Tecnológica

Sistema Nacional de Emprego

Secretaria Especial de Políticas para Mulheres

Fundo de Desenvolvimento das Nações Unidas para a

Mulher

Vara de Execuções Penais 


\section{LISTA DE GRÁFICOS}

Gráfico 1 - Faixa etária

Gráfico 2 - Estado Civil.

Gráfico 3 - Escolaridade

Gráfico 4 - Número de filhos

Gráfico 5 - Ocupação Anterior

Gráfico 6 - Continuar os Estudos

\section{LISTA DE MAPAS}

Mapa 1 - SEPLAN/CODEPLAN - Mapa DF por zona e Gama

\section{LISTA DE QUADROS}

Quadro 1 - Projetos desenvolvidos nos Estados durante o Projeto Piloto. Quadro 2 - Cursos do PMM oferecidos nos campi do IFB.

Quadro 3 - Resultados da Pesquisa. 


\section{SUMÁRIO}

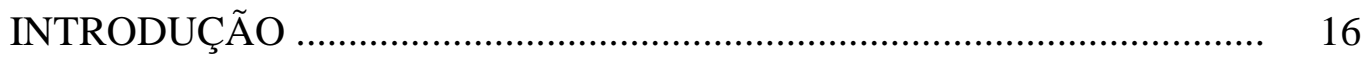

ESTRUTURA DO TRABALHO ……...................................................... 21

CAPITULO 1 ............................................................................. 21

1. POLÍTICAS PÚBLICAS E POLÍTICAS PÚBLICAS PARA MULHERES NO BRASIL .................................................................................... 21

1.1 A PARTICIPAÇÃO DA MULHER NO MUNDO DO TRABALHO .............. 24

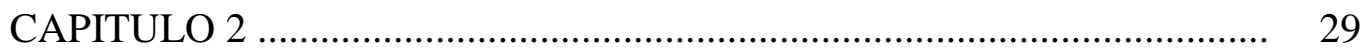

2. A EDUCAÇÃO PROFISSIONAL NO SISTEMA PRISIONAL BRASILEIRO

2.1 MULHERES EM RESTRIÇÃO DE LIBERDADE F.................................... 30

2.2 PROGRAMA MULHERES MIL NOS PRESÍDIOS ……………………..... 37

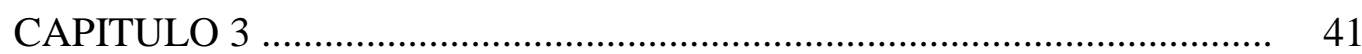

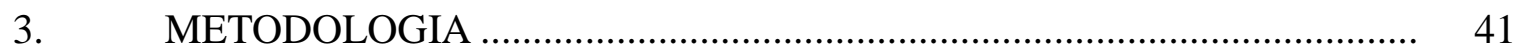

3.1 DELIMITAÇÃO METODOLÓGICA …………………………………….... 41

3.2 CAMPO E SUJEITOS DA PESQUISA ………………………………...... 43

$3.3 \quad$ PROCEDIMENTOS .......................................................................... 44

3.4 INSTRUMENTOS PARA LEVANTAMENTO DOS DADOS ..................... 45

3.5 TRATAMENTO DOS DADOS ……………………………………...... 47

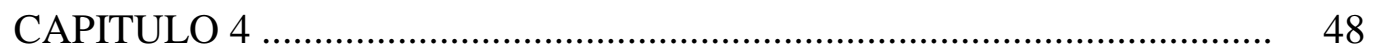

4. DESCRIÇÃO DO CONTEXTO ………………………………………..... 48

4.1 PRINCÍPIOS DO PROGRAMA MULHERES MIL ……………………...... 48

4.2 PROGRAMA MULHERES MIL-O INÍCIO: OS PROJETOS 'PILOTO' .... 50

4.3 O PROGRAMA MULHERES MIL NO IFB ............................................. 54

4.3.1 CRIAÇÃO DO INSTITUTO FEDERAL DE BRASÍLIA - IFB ................... 54

4.3.2 O CAMPUS GAMA …………………………………………………..... 56

4.3.3 O PROGRAMA MULHERES MIL NO IFB .............................................. 56

4.3.3.1 A EXPERIÊNCIA DO PROGRAMA MULHERES MIL NO CAMPUS

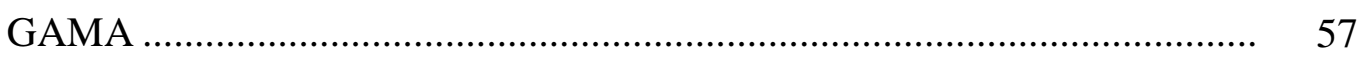

4.4 CONTEXTO SÓCIOECONÔMICO DA CIDADE ADMINISTRATIVA

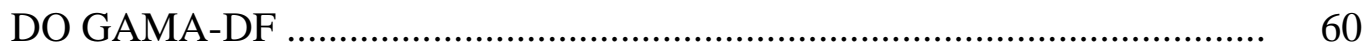

4.5 O SISTEMA PRISIONAL FEMININO NO DISTRITO FEDERAL ............. 61

4.5.1 CARACTERÍSTICAS DO PRESÍDIO FEMININO DO DISTRITO FEDERAL ……............................................................................... 62

4.6 PROGRAMA MULHERES MIL NO SISTEMA PRISIONAL 63

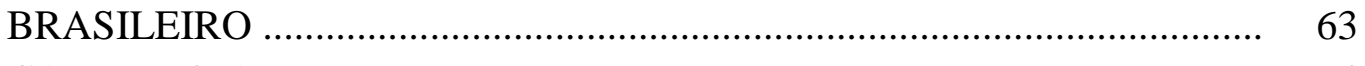

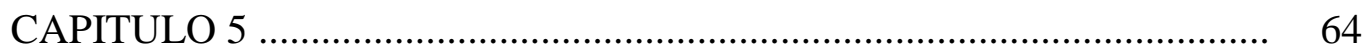

5. ANÁLISE DOS RESULTADOS DA PESQUISA DE CAMPO ................... 64

5.1 ANÁLISE DAS PERGUNTAS DISCURSIVAS …………………………... 76

5.1.1 ELEVAÇÃO DA AUTOESTIMA ……………………………………....... 76

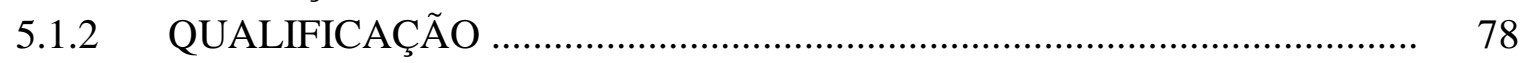

5.1.3 ANÁLISE DO GRUPO FOCAL …………………………………...... 80

5.2 CONSEQUÊNCIAS DO PROGRAMA MULHERES MIL PARA A 82 
RESSOCIALIZAÇÃO

5.2.1 ELEVAÇÃO DA AUTOESTIMA ……………………………………..... 82

5.2.2 INTERAÇÃO SOCIAL ……………………………………………...... 83

5.2.3 QUALIFICAÇÃO E GERAÇÃO DE RENDA ……………………………... 85

CAPITULO 6 …….................................................................... 88

6. MODELO SUSTENTÁVEL DO PROGRAMA MULHERES MIL PARA O SISTEMA PRISIONAL DO DISTRITO FEDERAL …………………….... $\quad 88$

6.1 A EXPERIÊNCIA DE RORAIMA …………………………………….... 89

6.2 MODELO SUSTENTÁVEL .................................................................. 93

6.2.1 OPORTUNIDADE DE RESSOCIALIZAÇÃO E GERAÇÃO DE RENDA PARA AS REEDUCANDAS DO PFDF POR MEIO DO PROGRAMA MULHERES MIL

CONSIDERAÇÕES FINAIS _.................................................................. 100

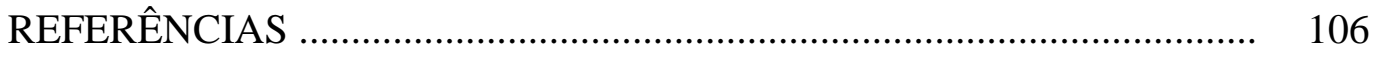

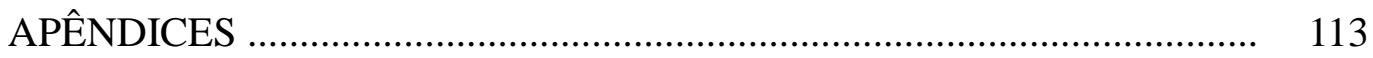

APÊNDICE A - Autorização do Coordenador do Programa Mulheres Mil no Campus Gama para a realização da pesquisa junto ao Presídio Feminino do Distrito Federal

APÊNDICE B - Autorização da Diretora Geral do Campus Gama para a realização da pesquisa junto ao Presídio Feminino do Distrito Federal ........ 116 APÊNDICE C - Termo de Consentimento do Questionário de Pesquisa ...... 118 APÊNDICE D - Termo de consentimento para participar do Grupo Focal .... 119 APÊNDICE E - Termo de Consentimento para a realização da Entrevista ... 121 APÊNDICE F - Questionário de Pesquisa semiestruturado .......................... 123 APÊNDICE G - Questionário Socioeconômico .......................................... 127 APÊNDICE H - Questões Chave para o Grupo Focal ................................ 129 APÊNDICE I - Solicitação à Secretaria de Segurança de autorização para Entrevista com Reeducandas

APÊNDICE J - Á Vara de Execuções Penais Solicitação de Autorização para Entrevista com Reeducandas 


\section{INTRODUÇÃO}

As políticas públicas são caracterizadas, segundo Lynn (1980), como um conjunto de ações do governo que irão produzir efeitos específicos. Peters (1986, apud Souza 2006, p. 4) reproduz o mesmo pensamento quando afirma que: "política pública é a soma das atividades dos governos, que agem diretamente, ou através de delegação, e que influencia a vida dos cidadãos".

Corroborando com esses pensamentos, percebe-se que, nos últimos anos, o Brasil vem experimentando uma forte tendência de inclusão social estimulada por programas de governo, focadas na erradicação da pobreza, na melhoria da distribuição da renda e elevação do poder aquisitivo da população. Com isso o estímulo ao aumento da capacidade produtiva e do crescimento econômico se baseia na modernização, na inovação tecnológica e prioritariamente, na qualificação do trabalho.

Sabe-se que políticas públicas sociais foram criadas com o objetivo de atender às demandas da sociedade, bem como para alocar e distribuir os bens públicos, todavia, para que haja efetivamente a ação legislativa e executiva dessas políticas, é preciso que elas façam parte da agenda governamental.

As demandas provenientes dos vastos setores da sociedade, bem como de pequenos grupos, é que irão dar início ao ciclo de definição da política pública. Segundo Subirats (2006), é por meio da mobilização que a sociedade civil organizada irá conseguir despertar a atenção para os problemas sociais gerais, ou de determinados grupos, os quais irão influenciar nas decisões políticas bem como na definição da agenda governamental.

Diante desse contexto, entende-se que são necessárias as conferências de políticas, por se tratarem de importantes instrumentos na elaboração e efetivação das políticas públicas. Graças as três conferências de políticas para as mulheres, que foram realizadas no Brasil, entre os anos de 2004 a 2011, é que foi elaborado o II Plano Nacional de Políticas para as Mulheres (PNPM), e "promover a autonomia econômica e financeira das mulheres, promover políticas de ações afirmativas no mundo do trabalho com inclusão social" é um dos principais objetivos deste plano. (BRASIL, 2008 p.40).

Por intermédio da análise dos documentos que compõem o conjunto de 
programas e ações do ensino profissionalizante, é possível afirmar que as novas leis, decretos e outros documentos surgem com o objetivo de transformar os Institutos Federais em Instituições de acolhimento da diferença social e econômica, por meio da profissionalização. A documentação oficial evidencia um conjunto de aspectos considerados importantes pelo governo, para a inclusão da diferença. A Educação Profissional e Tecnológica, de acordo com Pacheco (2011, p. 5.):

[...] tem pelo menos duas dimensões importantes, que são a dimensão da inclusão e também a da emancipação, na medida em que não apenas inclui a pessoa numa sociedade desigual, o que é insuficiente, mas lhe dá as ferramentas necessárias para que ela construa o seu itinerário de vida e possa se emancipar e se constituir como cidadã.

As instituições que formam hoje a Rede Federal de Educação Profissional, Científica e Tecnológica são originárias, grande parte, das dezenove escolas de aprendizes e artífices, criadas por Nilo Peçanha em 1909. Em 1937 essas escolas são transformadas em Liceus Industriais. Em 1942, após o ensino profissional ser considerado de nível médio, os liceus passam a se chamar escolas industriais e técnicas, e, em 1959, escolas técnicas federais, configuradas como autarquias. Ao longo desse mesmo tempo, vai se constituindo uma rede de escolas agrícolas - Escolas Agrotécnicas Federais, com base no modelo escola fazenda. Em 1978, três escolas federais: do Rio de Janeiro; de Minas Gerais e do Paraná são transformadas em Centros Federais de Educação Tecnológica (CEFET), equiparando-se, no âmbito da educação superior, aos centros universitários (PACHECO \& REZENDE, 2009).

Então, quase 100 anos depois do decreto de Nilo Peçanha, em 29 de dezembro de 2008, foi sancionada pelo então Presidente da República Luís Inácio Lula da Silva, a Lei n 11.892, que "institui a Rede Federal de Educação Profissional, Científica e Tecnológica, cria os Institutos Federais de Educação, Ciência e Tecnologia e dá outras providências”.

Como destaca Vidor et. Al. (2011, p. 49-50):

O foco dos Institutos Federais é a promoção da justiça social, da equidade, do desenvolvimento sustentável com vistas à inclusão social, bem como a busca de soluções técnicas e a geração de novas tecnologias. Essas instituições devem responder, de forma ágil e eficaz, às demandas crescentes por formação profissional, por difusão de conhecimentos científicos e de suporte aos arranjos produtivos locais. 
Nesta perspectiva, a partir do êxito da experiência do Projeto Mulheres Mil, em treze estados brasileiros, por meio dos Institutos Federais de Educação, Ciência e Tecnologia, em parceria com a Associação dos Colleges Comunitários Canadenses (ACCC) e com a Agência Canadense para o Desenvolvimento Internacional (CIDA), cria-se, em 2011, o Programa Mulheres Mil, expandindo as ações para todo o território nacional.

O Programa Mulheres Mil abrangerá Cursos e Programas de Educação Profissional e Tecnológica, incluindo a formação inicial e continuada de trabalhadores e a educação profissional técnica de nível médio. Os cursos e projetos do Mulheres Mil deverão:

\begin{abstract}
Considerar as características das mulheres atendidas, a fim de promover a equidade, igualdade de gênero, combate à violência contra mulher e acesso à educação e poderão ser articulados ao ensino fundamental ou ao ensino médio, objetivando a elevação do nível de escolaridade da mulher, no caso da formação inicial e continuada, nos termos dos arts. 35 a 42 da Lei no 9.394, de 20 de dezembro de 1996, e do art. 3o, § 2o, do Decreto no 5.154, de 23 de julho de 2004. Articulado ao ensino médio, de forma integrada ou concomitante, nos termos dos arts. 35 a 42 da Lei no 9.394, de 20 de dezembro de 1996, e do art. 3o, § 2o, do Decreto no 5.154, de 23 de julho de 2004 [...]
\end{abstract}

O Projeto Mulheres Mil foi desenhado em 2007, a partir da observância das diretrizes do governo brasileiro em torno da redução da desigualdade social e econômica de populações marginalizadas e do compromisso do país com a defesa da igualdade de gênero. Implantado pela Secretaria de Educação Profissional e Tecnológica do Ministério da Educação e Cultura (SETEC/MEC), contou com a parceria da Assessoria Internacional do Gabinete do Ministro (Al/GM), da Agência Brasileira de Cooperação (ABC/MRE), da Rede Norte Nordeste de Educação Tecnológica (Redenet), do Conselho Nacional das Instituições da Rede Federal de Educação Profissional, Científica e Tecnológica (CONIF), da Agência Canadense para o Desenvolvimento Internacional (CIDA/ACDI) e da Associação dos Colleges Comunitários do Canadá (ACCC) e Colleges parceiros. A execução foi realizada pelos Institutos Federais de Alagoas, Amazonas, Bahia, Ceará, Maranhão, Paraíba, Pernambuco, Piauí, Rio Grande do Norte, Roraima, Rondônia, Sergipe e Tocantins.

Por meio da educação escolar, cidadania e desenvolvimento sustentável, o Projeto Mulheres Mil (2011), se fundamentou nas metas globais de inclusão 
social e econômica de mulheres desfavorecidas, cujos objetivos estão presentes no III Plano Nacional de Políticas para as Mulheres - PNPM.

O III PNPM define metas a serem alcançadas para que sejam garantidas às mulheres, em especial as que se encontram em situação de vulnerabilidade social, seu ingresso e permanência no mercado de trabalho. Dentre estas metas está: "atender 180 mil mulheres em cursos de qualificação e elevação da escolaridade em processos e programas distintos e descentralizados; capacitar 100 mil mulheres até 2014" (BRASIL, 2012 p.15)

Conforme citado anteriormente, em 2011, o Projeto Mulheres Mil foi transformado em uma Política Pública Nacional, constituindo-se em um programa, desenvolvido em todos os Estados da federação, tendo como agentes os Institutos Federais de Educação, Ciência e Tecnologia, com o objetivo governamental de erradicação da miséria no país até 2014 (BRASIL, 2011).

Em 2011 o MEC e SETEC lançaram a chamada pública 01/2011, na qual foram selecionados 100 campi dos Institutos Federais para que fosse implantado o Programa Nacional Mulheres Mil. Dentre esses campi, o Campus Gama do IFB aderiu ao programa, para atender às reeducandas do Presídio feminino do Distrito Federal.

Este estudo se propõe a buscar respostas às seguintes indagações: 1) A formação profissional, por meio dos cursos de Estética Feminina e Recepcionista do Programa Mulheres Mil favoreceu a reinserção das egressas do Presídio Feminino do Distrito Federal na sociedade brasiliense? 2) O curso contribuiu para a inserção das egressas no mundo do trabalho? 3) O Curso proporcionou ferramentas necessárias à construção de itinerários emancipatórios de vida às egressas?

O presente trabalho tem como objetivo geral compreender as contribuições do Programa Mulheres Mil para as reeducandas do Complexo Penitenciário Feminino do Distrito Federal.

E como objetivos específicos:

- Identificar as consequências do curso para o aprendizado de uma ocupação e sua importância para a sociabilidade das reeducandas;

- Observar se as egressas construíram novos itinerários formativos de vida a partir das ferramentas fornecidas pelo Programa Mulheres Mil;

- Verificar as implicações dos cursos ofertados pelo programa para a 
reinserção das reeducandas, no mundo do trabalho;

Para embasar este estudo, levantaram-se algumas questões norteadoras de trabalho, a serem comentadas após a sua conclusão. Nesse sentido, elencamos as seguintes questões-problema para o estudo em tela:

- A formação recebida pelo Programa Mulheres Mil oportuniza a reinserção das reeducandas no mundo do trabalho?

- As reeducandas egressas estão trabalhando e gerando renda, mesmo estando em cumprimento de suas penas no interior do presídio?

- A renda familiar das egressas melhorou após a participação no programa?

- Os cursos ofertados contribuem para melhorar a atuação das reeducandas no trabalho que já desenvolvem?

- A formação recebida pelo Programa Mulheres Mil contribui para ressocialização das reeducandas?

A obtenção dos resultados a esses questionamentos foi realizada por meio da aplicação de questionários semiestruturados e da composição de um grupo focal, realizado com as reeducandas egressas. Ao final foi feita uma comparação das informações obtidas a partir das análises do questionário semiestruturado com as do grupo focal. 


\section{ESTRUTURA DO TRABALHO}

Esta dissertação foi estruturada em quatro partes distintas compostas de seis capítulos. Na parte I tem-se os capítulos I e II referentes a questão teórica. No primeiro capítulo buscou-se apresentar o conceito de políticas públicas e políticas públicas para mulheres enfatizando a participação da mulher no mundo do trabalho. O capítulo II apresenta a educação profissional no sistema prisional brasileiro, a situação dos presídios femininos e as mulheres em restrição de liberdade.

A parte II traz os capítulos III e IV. No capítulo III encontram-se a questão metodológica deste trabalho, a descrição do contexto onde é demonstrado o campo da pesquisa, seus participantes, os procedimentos e o tratamento dos dados coletados, são apresentados no capítulo IV.

Na parte III está o capítulo $\mathrm{V}$ apresentando análise dos resultados da pesquisa de campo.

A última parte, a que se refere ao capítulo $\mathrm{VI}$, apresenta um produto técnico, um modelo sustentável do programa Mulheres Mil no IFB para ser desenvolvido no sistema prisional do Distrito Federal. 


\section{CAPÍTULO 1}

\section{POLÍTICAS PÚBLICAS E POLÍTICAS PÚBLICAS PARA MULHERES NO BRASIL}

Nos Estados Unidos e na Europa, especialmente na Alemanha, as pesquisas em políticas públicas começaram a se estabelecer no início dos anos 1950, Frey (2000, apud TREVISAN 2008, p. 531). Já no Brasil, Faria (2003 apud LOTTA 2008, p. 02), nos elucida que os estudos de políticas públicas têm ganhado espaço apenas recentemente e, apesar do crescimento das pesquisas nas últimas duas décadas, o campo dessas ações ainda é incipiente devido à grande fragmentação organizacional temática.

De acordo com Moura, (2010), a legislação rege que as "políticas públicas que visam à justiça social, à educação e ao trabalho, considerando a inclusão, a diversidade e a igualdade" estabelecem que tais políticas, no que se refere "à formação cidadã e profissional" (p. 147), devem:

a) garantir a articulação entre formação cidadã e profissional, com enfoque no direito de acesso da adolescência e juventude ao ensino médio, tendo em vista a ampliação da etapa de escolarização obrigatória no Brasil, entendida como uma demanda da sociedade brasileira em um contexto social de transformações significativas e, ao mesmo tempo, de construção de direitos sociais e humanos.

b) Consolidar a expansão de uma educação profissional de qualidade, que atenda as demandas produtivas e sociais locais, regionais e nacionais, em consonância com a sustentabilidade socioambiental e com a inclusão social.

c) Construir uma educação profissional que atenda de modo qualificado, as demandas crescentes por formação de recursos humanos e difusão de conhecimentos científicos, e dê suporte aos arranjos produtivos locais e regionais, contribuindo para 0 desenvolvimento econômico-social.

Cumprindo o papel para o qual se propôs, o Programa Mulheres Mil está inserido no Plano Brasil sem Miséria e integra um conjunto de ações que consolidam as políticas públicas e diretrizes governamentais de inclusão educacional, social e produtiva de mulheres em situação de vulnerabilidade social. Ele possibilita que mulheres com idade entre 18 a 60 anos, moradoras de comunidades pobres, com baixo índice de desenvolvimento humano, sem pleno acesso aos serviços públicos básicos, ou integrantes dos Territórios da Cidadania, tenham uma formação educacional, profissional e tecnológica. Visam 
permitir sua elevação de escolaridade, emancipação e acesso ao mundo do trabalho, por meio do estímulo ao empreendedorismo, às formas associativas solidárias e à empregabilidade.

As ações do governo voltadas para as questões sociais são diversas e nesse sentido a literatura apresenta várias definições. No entanto, Souza (2006, p. 05) encontra, em suas pesquisas, várias definições que sintetizam o significado, de que as políticas públicas são um conjunto de ações do governo que visam produzir efeitos específicos na vida dos cidadãos; na perspectiva de que o todo é mais importante do que a soma das partes e que os indivíduos, instituições, ideologias e interesses contam, mesmo que existam diferenças sobre a importância relativa desses fatores.

Avaliação é uma operação na qual é julgado o valor de uma iniciativa organizacional, a partir de um quadro referencial ou padrão comparativo previamente definido. De acordo com Hofling (2001), na análise e na avaliação de políticas implementadas por um governo, fatores de diferentes natureza e determinação são importantes, especialmente quando se refere às políticas sociais. Para a avaliação dessas ações políticas, é fundamental se referir as chamadas "questões de fundo", as quais informam, basicamente, as decisões tomadas, as escolhas feitas, os caminhos de implementação traçados e os modelos de avaliação aplicados em relação a uma estratégia de intervenção governamental qualquer.

De certa maneira, as políticas públicas têm influência direta na sociedade, pois elas podem ser definidas como um conjunto de tomadas de decisões referente aos temas socialmente problematizados ou como resultado do debate entre Estado e sociedade sobre determinados problemas (OZLACK, 1982), que fazem a relação entre as ações do Estado e da sociedade. As decisões estão tão relacionadas aos aspectos econômicos e políticos que contribuem para os avanços e desenvolvimento da nação.

De acordo com Souza (2006), no processo de definição das políticas públicas, sociedade e Estado complexos como os constituídos no mundo moderno estão mais próximos da perspectiva teórica daqueles que defendem que existe uma autonomia relativa do Estado, o que faz que ele tenha um espaço próprio de atuação, embora permeável a influências externas e internas. 
De certa forma, argumenta-se que essa articulação capitalista gera acumulação financeira de capital o que caracteriza um estágio profundo de mudança na vida econômica, social, cultural e política.

Souza (2006), faz uma explanação acerca das diversas definições e modelos sobre políticas públicas, podemos extrair e sintetizar seus elementos principais citados a seguir:

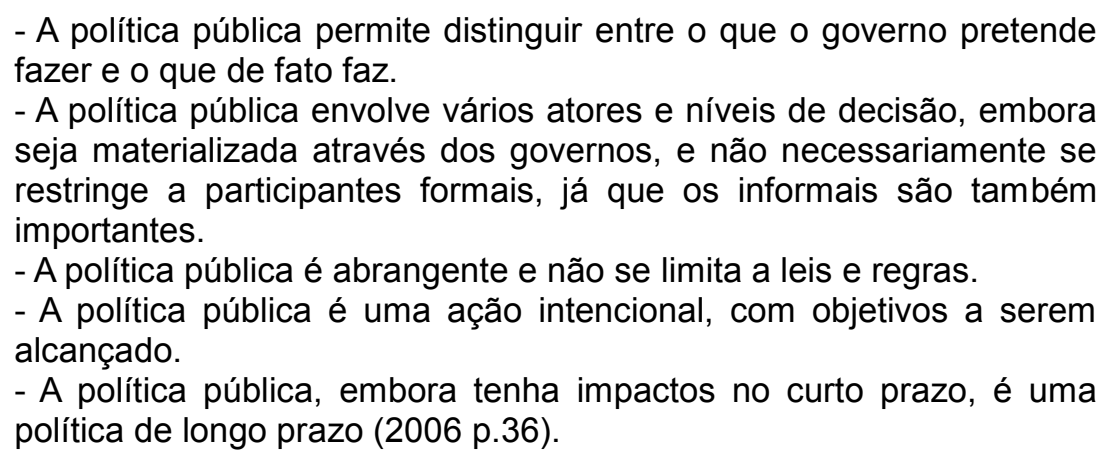

\subsection{A PARTICIPAÇÃO DA MULHER NO MUNDO DO TRABALHO}

Entre os anos de 2004 a 2011, após três grandes conferências, foi elaborado o II Plano Nacional de Políticas para as Mulheres (PNPM). Um dos objetivos do Plano é "promover a autonomia econômica e financeira das mulheres e promover políticas de ações afirmativas no mundo do trabalho com inclusão social" (BRASIL, 2008 p. 40).

O III PNPM, com vista a fortalecer a igualdade das mulheres no mundo do trabalho e sua autonomia, traz como objetivos a serem alcançados por meio das políticas públicas, dentre outros, "ampliar a participação e a permanência das mulheres no mundo do trabalho, garantindo a qualidade nas condições e igualdade de rendimentos e promover a organização produtiva e o acesso à renda para mulheres, especialmente daquelas em situação de vulnerabilidade social" (Idem, 2013 p. 14 e 15).

Ampliar a presença da mulher no mundo do trabalho com qualidade e igualdade de rendimentos é uma luta do movimento feminista desde a segunda metade do século XX. Os estudos de gênero revelam que a inserção da mulher e o seu crescimento no mercado de trabalho, desde os anos de 1950 até os dias atuais, têm sido marcados pelas desigualdades salariais e precárias condições de trabalho. 
As mulheres deixaram o contexto doméstico para exercer a função remunerada fora do aconchego do seu lar a partir da segunda metade do século XX. Esse processo suscitou novos modelos e arranjos familiares.

No momento em que a mulher é inserida no mundo do trabalho, ela passa a adquirir variadas atribuições, uma vez que seu papel de mãe, de dona de casa e de esposa inerente à função social antes ocupada, ainda se mantém, no entanto, sua dedicação não se limita exclusivamente ao lar. Essa nova mulher exerce agora inúmeros papéis simultaneamente, ela agora é a dona de casa, é estudante, profissional, realiza tarefas e exerce influências no meio social.

Embora com todas as atribuições da vida cotidiana, essa mulher administra seu tempo e se dedica aos filhos e a seu papel de esposa. Além de sua realização profissional, o trabalho está ligado também à própria subsistência e de sua família, pois, ademais das tarefas domésticas, suas atribuições também passam a ser de ordem financeira, uma vez que a sua renda agora é incorporada a renda familiar.

De acordo com Tavares (2010, p.122),

[...] no casamento moderno, a mulher, para ser respeitada, vê-se impelida a perseguir um crescimento do "eu" e da realização profissional, mesmo que não tenha um projeto pessoal ou desejo de exercer atividades domésticas. O marido, por sua vez, incentiva a sua esposa a estudar ou trabalhar, desde que não interfira nos serviços domésticos, cuidados com a família e filhos, que permanecem uma responsabilidade feminina.

Percebe-se que, por meio de muitas lutas, as mulheres conseguiram um espaço significante no mercado de trabalho. Todavia, apesar desta crescente inserção no mundo profissional, da busca contínua por capacitação e especialização, há que se percorrer longos caminhos em relação às questões de gênero. De acordo Giuzmán (2000, p. 68)

(...) as resistências que dificultaram e dificulta ainda a construção social da equidade de gênero como princípio organizador da democracia têm várias causas. Algumas resultam da inércia dos sistemas cognitivos e de valores. Outras estão relacionadas à rejeição dos homens a ver afetados seus interesses pela concorrência das mulheres nos espaços públicos associadas ao medo gerado pelas mudanças de identidade do outro ao questionar a própria identidade e à incerteza quanto ao próprio sentido e consequências das transformações em curso. Em resumo, aceitar mudanças na representação do feminino e do masculino nos sistemas de relações e práticas comuns aos dois gêneros não somente altera a situação da mulher como coloca em 
questão os conteúdos atribuídos à masculinidade e às práticas sociais associadas a ela.

Conforme Bruschini (1996), o trabalho feminino remunerado ganhou nova força a partir de 1970, com a expansão feminina da escolaridade e com o acesso à universidade e à informação, principalmente com as camadas da classe média. Foi uma revolução ideológica, pois com isso as mulheres passaram também a ocupar cargos públicos que antes eram ocupados somente por homens.

O número de mulheres trabalhadoras fora de casa, em todo mundo é de aproximadamente $50 \%$ de toda a população ativa. As mulheres assumem cada vez mais postos de trabalho em todos os setores, até mesmo aqueles considerados de exclusividade masculina. (BRASIL, 2008, p.11).

Em que pese esse número, a discriminação funcional salarial persiste
em relação a iguais funções do trabalho do homem pois, além de
constituir mão de obra mal remunerada, excluem-se do mercado de
trabalho milhares de mulheres que não tiveram oportunidade de
acesso à educação. (BRASIL, 2008, p11).

Nos últimos anos, as mulheres têm sido beneficiadas por um conjunto de programas de políticas públicas que tentam promover melhores condições e igualdade de gênero no trabalho (Bruschini, Lombardi e Unbehaum, 2003). Entretanto, estas ações, ainda que sistemáticas, não têm conseguido vislumbrar conquistas significativas no cenário mais amplo que minimizem as assimetrias de maior vulnerabilidade presentes na vida cotidiana desse grupo em particular.

Não obstante às intempéries sofridas em consequência das desigualdades de gênero, cresce a participação da mulher no mercado de trabalho e elas vêm desenvolvendo um grande potencial voltado para o mundo laboral nos últimos anos, conforme dados do MTE, (Ministério do Trabalho e Emprego, 2013), o crescimento de estoque de empregos masculinos foi menor que o crescimento de estoque feminino, em 2010 foi disponibilizado 18,3 milhões de postos de emprego feminino, em contrapartida em 2011 essa oferta alcançou a marca de 19,4 milhões, um crescimento de 5,93\%.

Segundo fonte do Portal do Planalto (2013):

Uma análise no Cadastro Nacional de Atividades Econômicas (Cnae) demonstra um maior crescimento da participação das mulheres principalmente nas atividades de administração pública (210.612 empregos), restaurantes (54.398), atividades de atendimento hospitalar (51.410), limpezas em prédios e domicílios (50.214), comércio varejista especializado em eletrodomésticos e equipamentos 
de áudio e vídeo (44.767). Até no setor de transporte rodoviário de carga, atividade tradicionalmente masculina, houve crescimento no saldo de emprego de mulheres (11.768 postos).

De acordo com os dados da Relação Anual de Informações Sociais (RAIS) de 2010, do Ministério do Trabalho, 42\% dos 44 milhões de trabalhadores formais no Brasil são mulheres. Vários autores mostram que esse crescimento de mulheres no mercado de trabalho é movido pela necessidade de contribuir para a manutenção da família. Atualmente, no Brasil, $37,4 \%$ dos lares são chefiados por mulheres, o que significa que elas são as únicas responsáveis pelo sustento da família (Idem, 2011).

A entrada da mulher no mercado de trabalho, conforme Ramos (2011) é um marco importante e representa uma mudança irreversível na estrutura da sociedade. Entretanto,

A dupla jornada resultante disto representa um fardo para as mulheres, cujo peso elas têm tentado administrar por meio da redução do tempo dedicado aos afazeres domésticos, visto que a negociação com os parceiros para a divisão da carga horária parece não estar acontecendo, ou não tendo os resultados desejáveis. (RAMOS, 2011, p. 33).

Com o objetivo de produzir indicadores para o acompanhamento conjuntural do mercado de trabalho nas regiões metropolitanas das principais capitais do Brasil, o IBGE implantou em 1980 uma pesquisa intitulada PME Pesquisa Mensal de Emprego. A PME é uma pesquisa domiciliar urbana que é realizada por meio de uma amostra probabilística, planejada de maneira segura para garantir os resultados para os níveis geográficos em que é realizada.

Com base na PME (1980):

As grandes transformações ocorridas no mercado de trabalho
brasileiro desde a implantação da PME impuseram uma revisão
completa, vigente desde março de 2002 , abrangendo seus aspectos
metodológicos e processuais. A modernização da Pesquisa Mensal de
Emprego visou a captação mais adequada das características do
trabalhador e de sua inserção no sistema produtivo, fornecendo, assim,
informações mais adequadas para a formulação e o acompanhamento
de políticas públicas. No que diz respeito a conceitos e métodos,
ocorreram atualizações de forma a acompanhar as recomendações da
Organização Internacional do Trabalho (OIT).

Pesquisas também apontam, conforme dados da PME/IBGE (2003-2011), que em 2011 as mulheres eram a maioria na população de 10 anos ou mais de idade (PIA) - população idade ativa (cerca de 53,7\%). O contingente de 
ocupadas em relação ao total da PIA era de 40,5\% em 2003, passando para 45,4\% em 2011.

No segundo Plano Nacional de Políticas para as Mulheres (PNPM), cujo objetivo principal é "promover a autonomia econômica e financeira das mulheres e também promover políticas de ações afirmativas no mundo do trabalho com inclusão social”, (BRASIL, 2008 p. 40), já estavam previstas as metas que constariam no III PNPM.

O III PNPM, busca fortalecer a igualdade das mulheres no mundo do trabalho e sua autonomia, as dez metas a serem cumpridas, trazem objetivos que só poderão ser alcançados por meio de políticas públicas que visem a ampliação, a participação e a permanência das mulheres no mundo do trabalho, garantindo a qualidade nas condições e igualdade de rendimentos e promovam a organização produtiva e o acesso à renda para mulheres, especialmente das em situação de vulnerabilidade social” (Idem, 2013 p. 14 e 15).

\footnotetext{
Ampliar a presença da mulher no mundo do trabalho com qualidade e igualdade de rendimentos é uma luta do movimento feminista desde a segunda metade do século $X X$. Os estudos de gênero revelam que a inserção da mulher e o seu crescimento no mercado de trabalho, desde os anos de 1950 até os dias atuais, têm sido marcados pelas desigualdades salariais e condições de trabalho. (RIBEIRO, 2013)
}

Aponta-se aqui uma dificuldade que já se faz presente em nosso meio desde a segunda metade do século vinte; a ampliação da presença da mulher no mundo do trabalho, com qualidade e igualdade de rendimentos. Embora muito já se tenha feito para solucionar, ou mesmo minimizar esta situação, ainda há que se empreender esforços na execução de políticas públicas que beneficiem as mulheres, sobretudo às que são colocadas em posição de chefe de família em função de variadas situações, especialmente as que se encontram em situação de viuvez, viúvas, do (tráfico ou da Aids), abandono, separação motivada pela violência doméstica, pela ausência temporária do cônjuge, que saiu à procura de trabalho em outros estados, as mulheres encarceradas etc. 


\section{CAPÍTULO 2}

\section{A EDUCAÇÃO PROFISSIONAL NO SISTEMA PRISIONAL BRASILEIRO}

Embora se saiba que a educação está diretamente relacionada ao desenvolvimento de um país, e que por meio da educação a sociedade se transforma tanto no aspecto cultural, econômico e social, a possibilidade de se desenvolver a educação num ambiente hostil como o prisional ainda é muito difícil, de ser realizada em sua totalidade. Segundo Rocha (1994, p.55), as prisões causam uma profunda repulsa, devendo as "pessoas boas" delas guardarem a mais absoluta repulsa. Entretanto a educação ofertada às mulheres reeducandas traz benefícios individuais e sociais. Conforme Nonato (2010), a educação realizada no ambiente prisional adquire pleno sentido, pois possibilitará à população carcerária ser incluída em outro universo. Universo esse ligado ao conhecimento, à construção de projetos de vida e de qualificação profissional. A educação deve ser concebida com a finalidade de dar à pessoa condição para continuar a viver bem consigo mesma e de viver de forma digna na sociedade.

Recentemente, o Ministério da Educação e Cultura e Cultura - MEC fortaleceu a discussão de políticas públicas de ações afirmativas junto às universidades públicas com o objetivo de reserva de vagas para a garantia de participação de negros e indígenas, (PNPM - Plano Nacional de Políticas para as Mulheres, 2004, p.55). Não se pretende com isso, apontar que as mulheres privadas de liberdade, se insiram na educação inclusiva. Entretanto não se observa a implementação de políticas, especificamente na área de educação profissional, destinada à essas mulheres, nem tão pouco no Plano Nacional de Políticas para as Mulheres. Da mesma forma, e apesar de a Lei de Execuções Penais - LEP, prever o ensino profissionalizante a apenados, ainda não se observa menção específica, na Lei de Diretrizes e Bases - LDB/1996, à educação de mulheres em restrição de liberdade. 


\subsection{MULHERES EM RESTRIÇÃO DE LIBERDADE}

Apesar de o MEC ter criado a Secretaria de Educação Continuada, Alfabetização e Diversidade (SECADI), com o propósito de elaborar e implementar políticas públicas de ações afirmativas, objetivando o acesso, sucesso e permanência de indígenas e negros - incluindo os quilombolas - em todo o sistema de ensino, não foi prevista naquela Secretaria, nenhuma política direcionada à mulheres privadas de liberdade, visto que a prisão é considerada esforço residual no âmbito das políticas públicas para a população carcerária, mesmo apresentando características muito parecidas com as da população brasileira, ou seja, ambas são compostas por indivíduos pobres, com pouca ou nenhuma escolaridade.

O único item direcionado à educação no cárcere que está previsto em Lei, encontra-se registrado nas metas do PNE (Plano Nacional da Educação), item 9.8 onde se lê: "assegurar a oferta de educação de jovens e adultos, nas etapas de ensino fundamental e médio, às pessoas privadas de liberdade em todos os estabelecimentos penais, assegurando-se a formação específica dos professores e das professoras e implementação de diretrizes nacionais em regime de colaboração".

$\mathrm{O}$ que se tem de novo e mais recente em termos legais e direcionados para as necessidades das mulheres com restrição de liberdade é a Portaria Interministerial (Ministério da Justiça e Secretaria de Políticas para as Mulheres da Presidência da República) número 210, de 16 de janeiro de 2014 (Diário Oficial da União, 2014), que Institui a Política Nacional de Atenção às Mulheres em Situação de Privação de Liberdade e Egressas do Sistema Prisional, e também dá outras providências.

Entre suas diretrizes está a prevenção de todos os tipos de violência, o fortalecimento da atuação conjunta e articulada de todas as esferas de governo na sua implementação, incluindo o fomento à participação das organizações da sociedade civil no controle social desta política; a humanização das condições do cumprimento da pena, garantindo o direito à saúde, educação, alimentação, trabalho, segurança, proteção à maternidade e à infância, lazer, esportes, assistência jurídica, atendimento psicossocial e demais direitos humanos; fomento à elaboração de estudos, organização e divulgação de dados, visando 
à consolidação de informações penitenciárias sob a perspectiva de gênero; o incentivo à formação e capacitação de profissionais vinculados à justiça criminal e ao sistema prisional, por meio da inclusão da temática de gênero e encarceramento feminino na matriz curricular e cursos periódicos; e ao desenvolvimento de ações que visem à assistência às pré-egressas e egressas do sistema prisional, por meio da divulgação, orientação ao acesso às políticas públicas de proteção social, trabalho e renda.

Nas suas metas previstas no artigo $4^{\circ}$ inciso c estão: acesso à educação em consonância com o Plano Estratégico de Educação no âmbito do Sistema Prisional e as Diretrizes Nacionais para a Oferta de Educação para Jovens e Adultos em Situação de Privação de Liberdade nos Estabelecimentos Penais, associada a ações complementares de cultura, esporte, inclusão digital, educação profissional, fomento à leitura e a programas de implantação, recuperação e manutenção de bibliotecas.

Nesse sentido vemos assentar a importância dos processos educativos dentro dos presídios femininos e masculinos. É claro que, ao pensar dessa forma, não se diz que a educação é a "tábua de salvação" ou mesmo se atribui a função redentora a ela, mas sim em reconhecer a sua importância no campo de força existente entre a emancipação social que aponta para a integração social dos indivíduos livres ou encarcerados, e a reguladora que aponta para os processos excludentes.

Com base em Nonato, (2010), a perspectiva da educação nas prisões, ainda longe de ser consolidada, parece fazer parte da agenda da crescente presença de militantes dos direitos humanos, situados em nível local e nacional, que cobram dos poderes públicos a consolidação do Estado Democrático de Direito, tornando a construção de uma política pública de segurança nacional uma questão de pauta dos últimos governos.

As prisões femininas, historicamente, surgem da necessidade de atendimento a esse público diferenciado e específico, era comum se realizar prisão de mulheres de forma improvisada, sem atentarem ao atendimento das condições necessárias e próprias inerentes à mulher. $O$ que se percebe atualmente são prisões construídas para homens que; se assemelham em suas formas de organização a modos de organização social específicos para o sexo masculino. Para Louro (2008, p.89), "É impossível pensar sobre a instituição sem 
que se lance mão das reflexões sobre as construções sociais e culturais de masculino e feminino".

Com o intuito de promover reformas com vistas à regulamentação geral das prisões brasileiras, o governo, na década de 1930, adotou as seguintes medidas: aplicou, em 1930, o Regimento das Correições que pretendia reorganizar o regime carcerário; criou, em 1934, o Fundo e o Selo Penitenciário, a fim de arrecadar fundos para investimento nas prisões; em 1935, também criou o Código Penitenciário da República, que passou a legislar sobre o ordenamento de todas as circunstâncias que envolviam a vida do indivíduo condenado pela Justiça; e instaurou o novo Código Penal em 1941, (REVISTA ÂMBITO JURÍDICO, 2009).

Os anos de 1930 a 1945, conhecidos como "a Era Vargas", foram marcados por reformas legislativas que evidenciavam além da centralização do poder político, a tentativa da instalação de um Estado liberal, dando condições para a continuidade do processo de acumulação (SANTOS. 1979). Mas apenas em 1940 é que foram tomadas as primeiras medidas efetivas, por parte do Estado, visando à acomodação de mulheres que cometeram crimes. A primeira diretriz legal foi determinada pelo Código Penal e pelo Código de Processo Penal, ambos de 1940, e pela Lei das Contravenções Penais, de 1941. Desta forma, no $2^{\circ}$ parágrafo, do Art. $29^{\circ}$, do Código Penal de 1940 , determinou-se que "as mulheres cumprem pena em estabelecimento especial, ou, à falta, em secção adequada de penitenciária ou prisão comum, ficando sujeitas a trabalho interno". Visto isso, a prisão feminina foi criada no Brasil no início dos anos 1940, no mesmo momento em que acontecia a reforma penal.

Em 1941, surgiu em São Paulo o Presídio de Mulheres, junto ao Complexo do Carandiru, e que alguns anos depois tornou-se a Penitenciária Feminina da Capital. Em 1942, no Rio de Janeiro, é criada a Penitenciária das Mulheres, depois chamada Presídio Feminino Talavera Bruce. É nesse período que ocorre pela primeira vez no país a separação de celas por sexo (LIMA, 1983). Na origem histórica das prisões femininas no Brasil, destaca-se a vinculação do discurso moral e religioso nas formas de aprisionamento da mulher. $O$ encarceramento feminino, norteado por uma visão moral, inspirou a criação de um estabelecimento prisional destinado às mulheres, denominado "reformatório especial", uma vez que, a criminalização mais frequente era relacionada à 
prostituição, vadiagem e embriaguez. Veiculava-se a ideia de separação das mulheres chamadas "criminosas" para um ambiente isolado de "purificação", numa visão de discriminação de gênero assumida pela construção do papel da mulher como sexo frágil, dócil e delicado. A intenção era que a prisão feminina fosse voltada à domesticação das mulheres criminosas e à vigilância da sua sexualidade. Tal condição delimita na história da prisão os tratamentos diferenciados para homens e mulheres (LIMA, 1983).

No Brasil, entre 1957 e 1971, as condenações de mulheres cresceram duas vezes mais rapidamente do que as de homens, e, paralelamente, a participação da mulher brasileira na população economicamente ativa passa de 14,7\% em 1950, para 17,9\% em 1960, e finalmente, 21,0\% em 1970 (LENGRUBER, 1983). Segundo o Instituto Brasileiro de Geografia e Estatística (IBGE), a população brasileira atual é de cerca de 183.987.291 pessoas. Distribuído por um espaço geográfico de mais de 8 milhões de quilômetros quadrados, o povo brasileiro, cujo perfil demográfico é marcado por alarmantes índices de desigualdade, apresenta uma enorme faixa de pobreza. Desemprego, fome, miséria e concentração de renda compõem o cenário onde se estabelecem as relações sociais no Brasil. Entre as diversas consequências dessa realidade está o visível aumento da criminalidade. De acordo com Durkheim (2003, p. 82), "o crime não se observa só na maior parte das sociedades desta ou daquela espécie, mas em todas as sociedades de todos os tipos. Não há nenhuma em que não haja criminalidade".

No mundo, a partir dos anos de 1960, com as transformações sociais, econômicas, políticas e culturais ocorre uma mudança efetiva na divisão de papeis sociais historicamente atribuídos a homens e a mulheres.

A criminologia, posteriormente, desperta para o aparato legal e as formas de controle social organizadas sob o ponto de vista masculino de origem patriarcal. Assim, a mulher era vislumbrada em uma posição desigual no direito penal.

Ao longo das últimas décadas, a criminalidade urbana no Brasil, em razão de seu crescimento e de sua intensificação, tem sido motivo de preocupação de vários setores da sociedade. De acordo com dados de 2007 do INFOPEN Ministério da Justiça, o Brasil tem a $8^{a}$ maior população carcerária do mundo. Em 1995 tínhamos 95 presos para cada 100.000 habitantes. Em 2007 chegamos 
a 227 presos para cada 100.000 habitantes. A taxa de delinquência feminina, no Brasil, na década de 50 era de $2 \%$ em relação à masculina. Já no ano de 2000 , passou a representar $3,5 \%$ de toda a população carcerária brasileira (a população carcerária feminina até novembro de 2000 era de 9.949 presas). São raros, ou quase não existem estudos que tratam da criminalidade feminina em relação à criminalidade em geral. Consequentemente, os dados são escassos e pouco reveladores da real dimensão deste fenômeno social (FRINHANI e SOUZA, 2005).

Dados penitenciários nos mostram que a proporção da população carcerária feminina se mantém em torno de $5 \%$ da população carcerária total, sendo estatisticamente bem menor que o número de homens encarcerados, porém em constante elevação.

No Presídio Feminino do Distrito Federal - PFDF, a maioria das mulheres encarceradas foi presa por tráfico ou associação para o tráfico de drogas, mas independente do motivo que as levou a essa situação de privação da liberdade, elas agora terão de viver em uma outra realidade. Neste sentido Nonato, (2010), relata sobre uma linha abissal que passa a existir no instante em que o indivíduo perde sua cidadania ao adentrar no sistema penitenciário, para ela as mulheres apenadas vivem um distanciamento muito grande da sociedade, uma verdadeira linha abissal existente entre a população prisional e a sociedade, e isso parece satisfazer a exigência social punitiva, e não ocorre apenas no sentido do cumprimento da pena restritiva da liberdade, do pagamento do delito cometido, mas no aspecto do disciplinamento, da exclusão e da moralização.

Ao chegarem ao espaço prisional, o processo de admissão é um teste de obediência que pode ser desenvolvido como uma espécie de iniciação, o qual se convencionou de "boas-vindas", nesse momento a equipe carcerária, ou mesmo as internas, procuram dar à novata noção de regras do novo ambiente onde elas irão viver, que nada mais é do que um vasto conjunto de regras de prescrições e proibições quanto a conduta da apenada.

Segundo Onofre (2007, p.12),

Os presos fazem parte da população dos empobrecidos, produzidos por modelos econômicos excludentes e privados de seus direitos fundamentais de vida. Ideologicamente como os "pobres" são jogados em um conflito entre as necessidades básicas vitais e os centros de poder e decisão que as negam. São com certeza, produtos da 
segregação e do desajuste social, da miséria e das drogas, do egoísmo e da perda de valores humanitários. Pela condição de presos, seus lugares na pirâmide social são reduzidos à categoria de "marginais", "bandidos", duplamente excluídos, massacrados e odiados.

Ao se proceder a uma análise das prisões, Foucalt (1987) aponta que elas possuem mecanismos internos de repressão e de punição que ultrapassam o castigo da "alma", investindo na regulação do corpo do detento pela coação estimulada por uma educação total reguladora de todos os movimentos do corpo. E nesse sentido, além da privação da liberdade, elas executam uma transformação técnica nos indivíduos.

Conforme Onofre (2007, p.14),

A prisionalização dificulta os esforços em favor da ressocialização; além disso, em vez de devolver à liberdade aos indivíduos educados para a vida social, devolve para a sociedade delinquentes mais perigosos, com elevado índice de possibilidade para a reincidência.

No interior dos presídios femininos, as mulheres executam as mesmas tarefas domésticas que faziam antes de serem presas, pois existe pouca diversidade nas ocupações às quais as presas podem ter acesso. Essas mulheres são geralmente reconduzidas aos papéis e aos espaços domésticos, inclusive e especialmente à submissão masculina. De acordo com Wolf (2007),

\begin{abstract}
A maioria das mulheres está ocupada com o artesanato e a faxina, ou então, com tarefas como chaveiras (abre e fecha portas) e manicures, funções exercidas dentro dos espaços das galerias e das celas femininas. As demais que trabalham estão alocadas na cozinha da Administração, no serviço burocrático e na faxina do saguão.
\end{abstract}

As mulheres apenadas constituem, em média, metade da população livre nos diferentes países e apenas cerca de $5 \%$ da população carcerária. Não obstante, na maior parte do mundo, o número de mulheres presas vem crescendo de forma muito célere e, em algumas regiões, muito mais rapidamente do que o número de homens presos, conforme dados do DEPEN Departamento Penitenciário Nacional, 2012).

Entre os países da América Latina, o Brasil é o país com a maior população prisional atualmente. A População Carcerária Masculina cresceu $130 \%$ entre 2000 e 2012 e a feminina cresceu $246 \%$ no mesmo período. Enquanto a população carcerária masculina mais que dobrou, a feminina mais 
que triplicou nesse período. No ano 2000 eram 10.112 mulheres presas e em 2012 o número saltou para 35.039 (INFOPENINFOPEN/DEPEN/MJ, 2012). Entretanto esse número vem crescendo a cada dia. De acordo com os dados do primeiro relatório nacional sobre a população carcerária feminina do Brasil, lançado em novembro de 2015 pelo Ministério da Justiça nos diz que:

[...] O levantamento, com dados relativos a junho de 2014, traz o número de mulheres privadas de liberdade nos últimos 15 anos, a taxa de encarceramento feminino por grupo de 100 mil habitantes e o comparativo com outros países. Segundo o relatório INFOPEN Mulheres, a população penitenciária feminina subiu de 5.601 para 37.380 detentas entre 2000 e 2014 , um crescimento de $567 \%$ em 15 anos. A taxa é superior ao crescimento geral da população penitenciária, que teve aumento de $119 \%$ no mesmo período. (Levantamento Nacional de Informações Penitenciárias, 2015) (BRASIL, 2015).

Com relação às características da mulher brasileira encarcerada, o primeiro relatório nacional sobre a população carcerária feminina do Brasil relata que elas podem ser descritas como jovem, não branca, condenação por tráfico ou associação para o tráfico de drogas.

\begin{abstract}
O relatório traz também um perfil das mulheres privadas de liberdade por escolaridade, cor, faixa etária, estado civil, além do percentual de presas por natureza da prisão, (provisória ou sentenciada) e tipo de regime (fechado, semiaberto ou aberto) e a natureza dos crimes pelas quais foram condenadas. Um dos dados que mais chamam a atenção é o percentual de mulheres presas pelo crime de tráfico de drogas: $68 \%$. (INFOPEN/Mulheres, 2015)
\end{abstract}

Quanto à escolarização, segundo o relatório, a maioria delas possui somente o ensino fundamental completo. Em relação ao motivo que as levou ao crime, a maior parte destas mulheres sofre influências de seus companheiros, filhos, parentes ou amigos que resulta em suas detenções e encaminhamento ao presídio. Esses indivíduos as induzem ao cometimento ou participação do crime, ou então, a assumir a culpa sozinha para livrá-los do cárcere, servindo como "escudo" contra a ação policial e outra vez vítima de sua própria natureza. Grupo de Trabalho Interministerial (2008).

No Brasil, em 2012, apenas 9\% da população carcerária estava em atividade educacional. Entre as mulheres essa taxa era de 13\%, enquanto entre os homens não passou de $8 \%$. No total, 42.798 homens e 4.555 mulheres estudavam, ou seja, 86,4 para cada 1.000 presos. O estado com o maior número 
de presos estudando entre os homens foi Pernambuco, com 24\% dos presos estudando. Já entre as mulheres, o Ceará teve um melhor desempenho, com $48 \%$ das presas em atividade educacional. O Ensino Fundamental é responsável por $61 \%$ dos alunos (INFOPEN/DEPEN/MJ, 2012).

O Brasil enquadra-se entre os países mundiais com o maior número de mulheres privadas de liberdade. Conforme dados do Ministério da Justiça (2015), os Estados Unidos estão no primeiro lugar com 205.400 mulheres presas, a China em segundo com 103.766, a Rússia está em terceiro com 53.304, a Tailândia em quarto com 44.751 e o Brasil, figurando em quinto com 37.380 mulheres encarceradas. Portanto, ele ocupa a quinta posição no ranking mundial. (INFOPEN/Mulheres, 2015, p. 9).

Com relação à taxa de aprisionamento, o Brasil apresenta um índice menor que o figurado no ranking nacional de mulheres presas. De acordo com o INFOPEN,

No Brasil, as mulheres compõem $6,4 \%$ do total, situando o país dentro da margem projetada pelo instituto. Em relação à taxa de aprisionamento, que indica o número de mulheres presas para cada 100 mil habitantes, o Brasil figura na sétima posição mundial, com uma taxa de 18,5 mulheres presas a cada 100 mil habitantes, ficando atrás da Tailândia $(66,4)$, Estados Unidos $(64,6)$, Rússia $(36,9)$, Taiwan $(23,0)$, Vietnã $(22,2)$ e Myanmar $(18,8)$. INFOPEN/Mulheres, 2015, p. 9).

\subsection{PROGRAMA MULHERES MIL NOS PRESÍDIOS}

O Programa Mulheres Mil é fomentado pelos Institutos Federais de Educação, Ciência e Tecnologia do Brasil. No início de 2014, o Ministério do Desenvolvimento Social e Combate à Fome (MDS) e o Ministério da Educação e Cultura (MEC) firmaram parceria para integrar o Programa Mulheres Mil ao Programa Nacional de Acesso ao Ensino Técnico e Emprego no âmbito do Plano Brasil Sem Miséria (Pronatec/BSM). Ao aproximar a temática da qualificação profissional de mulheres à Rede sócio assistencial, o Pronatec/BSM Mulheres Mil amplia a oferta de qualificação profissional às mulheres mais pobres, em especial às beneficiárias do Programa Bolsa Família, incluindo às mulheres privadas de liberdade que cumprem pena nos presídios.

No âmbito dos presídios femininos, o Programa Mulheres Mil desenvolve 
cursos pelo (Pronatec/BSM) em diversos Estados da Federação: RR (IFRR), RS (IFRS), SC (IFSC e IF Catarinense), RO (IFRO), TO (IFTO), MA (IFMA), MS (IFMS), PB (IFPB), AP (IFAP), GO (IFGO e IF Goiano), RJ (IF Fluminense) e DF (IFB).

Embora muitos presídios femininos do Brasil sejam contemplados com os cursos de qualificação profissional oferecidos pelos Institutos Federais no âmbito do Programa Mulheres Mil, não se observou, em nenhum desses Estados anteriormente citados, um programa que seja sustentável, no sentido de promover a geração de renda às reeducandas no período em que elas ainda estejam no cumprimento de suas penas. De acordo com a Lei de Execuções Penais, LEP, (1984), Art. 19, deve ser proporcionado à mulher condenada um ensino profissionalizante, uma qualificação profissional que seja adequada a sua condição.

\begin{abstract}
"Nem sempre a liberdade é o valor mais importante para as mulheres, mesmo para aquelas que estão privadas temporariamente dela. Família, futuro e oportunidade foram os valores mais citados durante dinâmica de apresentação na aula inaugural do curso de Artesão em Bordado à Mão, ofertado pelo Campus Joinville no Presídio Regional de Joinville, através de parceria com o Ministério da Justiça. Para o grupo de quinze mulheres, fazer um curso de qualificação profissional é uma oportunidade de obter renda para sustentar a família e garantir um futuro digno para si e seus filhos, quando voltarem à liberdade" (IFSC-Campus Joinville).
\end{abstract}

No Estado de Roraima, em 2010, durante o desenvolvimento do Curso de culinária regional, que foi ministrado pelo Instituto Federal de Roraima no âmbito do Projeto Mulheres Mil e ofertado às reeducandas da Penitenciária Agrícola do Monte Cristo (PA), iniciou-se uma cooperativa para confeccionar alimentos variados, entre os quais: doces e salgados para os eventos realizados na SEJUSC e no IFRR e também as refeições consumidas diariamente por elas. Esses alimentos eram comercializados no interior do presídio para os servidores da carceragem e para os visitantes, o que gerava uma renda para as detentas e seus familiares.

Entretanto, após o projeto se tornar Programa Nacional Mulheres Mil, não se observou a continuidade de ações semelhantes às executadas no presídio do estado de Roraima, que possibilite as reeducandas gerar renda com o trabalho realizado a partir da qualificação recebida pelo programa Mulheres Mil. 
De acordo com Cusinato (1982), o aprendizado de um ofício paralelo à formação escolar, com o objetivo de suavizar o retorno do recluso à sociedade, cede lugar a exploração da mão de obra presidiária, para atingir o objetivo da "autossuficiência", da diminuição dos custos para o Estado. Ele nos ensina ainda que:

\footnotetext{
O trabalho para o recluso não é obrigatório, servindo como meio de disciplina e como forma de impedir a angústia desesperante e as deformações mentais da reclusão na ociosidade. É oferecido como um instrumento de ressocialização do condenado pela criação do hábito de uma atividade produtiva, pelo aprendizado de um ofício e pela formação de um pecúlio que lhe dará meios de enfrentar as primeiras dificuldades na vida livre.
}

Como foi citado anteriormente, catorze, dos trinta e oito Institutos Federais do Brasil, desenvolvem o Programa Mulheres Mil no âmbito dos presídios, contudo não nos foi informado, por meio da SETEC/MEC, se, ao aderir ao Pronatec/BSM, o programa continua sendo desenvolvido nos moldes em que os Projetos Pilotos foram implantados. Não se tem informação a respeito de parcerias com instituições públicas ou privadas que possibilitem a inserção das egressas no mundo do trabalho, e se as reeducandas trabalham e recebem remuneração ainda no período em que estão cumprindo pena em regime fechado, ou se foram inseridas no mercado de trabalho e contribuem com 0 sustento da família. Da mesma forma não há ainda o registro de informações a respeito de parcerias com as Secretarias de Educação para ser realizada a elevação da escolaridade.

Espera-se que a realização deste estudo, que visa compreender as contribuições do Programa Mulheres Mil para a reinserção social cidadã das reeducandas do presídio feminino do Distrito Federal, possibilite o esclarecimento desses questionamentos e conceda o aporte necessário para outras pesquisas do programa no âmbito do sistema prisional. 


\section{CAPÍTULO 3}

\section{METODOLOGIA}

\subsection{DELIMITAÇÃO METODOLÓGICA}

A delimitação metodológica eleita para esta pesquisa foi a qualitativa, na qual observa-se um caráter exploratório, isto é, estimula os entrevistados a pensarem livremente sobre algum tema, objeto ou conceito. Mostra aspectos subjetivos e atinge motivações não explícitas, ou mesmo conscientes, de maneira espontânea. É utilizada quando se busca percepções e entendimento sobre a natureza geral de uma questão, abrindo espaço para a interpretação. De acordo com Chizzotti (2010, p. 28), "o termo qualitativo implica uma partilha densa com pessoas, fatos e locais que constituem objetos de pesquisa, para extrair desse convívio os significados visíveis e latentes que somente são perceptíveis a uma atenção visível".

O método qualitativo tem suas raízes na fenomenologia, pois busca a compreensão da dinâmica do Ser Humano, partindo dos significados dos fenômenos vivenciados pelas pessoas (TURATO, 2005; FONTANELLA et. al., 2006).

A pesquisa qualitativa, segundo Oliveira (1999 p.117) pode ser caracterizada como sendo uma tentativa de se explicar em profundidade 0 significado e as características do resultado das informações obtidas através de entrevistas ou questões abertas, sem mensuração quantitativa de características ou comportamento.

A escolha dessa abordagem fundamenta-se na compreensão de que ela possibilita descobrir as múltiplas facetas de um objeto e é indispensável para conhecer o significado que as pessoas atribuem ao que está ao seu redor e à sua própria vida, conforme afirmam Ludke e André (1986).

Segundo Oliveira (2004), as pesquisas que se utilizam da abordagem qualitativa possuem a facilidade de compreender e classificar processos dinâmicos experimentados por grupos sociais, bem como se preocupam em entender a complexidade, os significados e as mudanças.

A pesquisa qualitativa compreende o universo de significados, motivos, aspirações, crenças, valores e atitudes e, portanto, não se trata apenas de um 
conjunto de técnicas, mas de um modo especial de olhar o fenômeno social investigado (MINAYO, 1994).

O estudo apresenta uma pesquisa qualitativa. Essa escolha deve-se à compreensão de que a utilização desta abordagem torna o estudo mais amplo. Os estudos de pesquisa qualitativa diferem entre si quanto ao método, à forma e aos objetivos. Godoy (1995, p. 62) ressalta a diversidade existente entre os trabalhos qualitativos e enumera um conjunto de características essenciais capazes de identificar uma pesquisa desse tipo.

Os métodos qualitativos empregam, conforme observa Creswell (2010, p. 206), várias concepções filosóficas; estratégias de investigação e métodos de coleta de dados, análise e interpretação. Além de detalhar as características da pesquisa qualitativa, o autor apresenta também "dicas de pesquisa" voltadas para as estratégias de investigação. O papel do investigador, em seguida, ganha igual destaque tratando, inclusive, sobre as questões éticas na relação pesquisadores-participantes.

A escolha de um tipo de abordagem e um determinado instrumento de pesquisa é fundamental, porque o pesquisador necessita estar ciente dos avanços e limitações que vão ser enfrentados, devido a elementos que aparecem inesperadamente no transcorrer da mesma. Há uma necessidade de o investigador possuir domínio do arcabouço teórico e das técnicas utilizadas, para poder, a partir daí, desenvolver suas ações de maneira eficiente e segura.

Por se pretender entender as percepções e as experiências dos participantes, assim como a maneira como eles extraem sentidos para suas vidas, optou-se pela pesquisa qualitativa (CRESWELL, 2010).

Com o intuito de valorizar as expressões, pensamentos, atitudes, expectativas das informantes, bem como de acreditar que elas trazem informações preciosas para a pesquisa e que também devem ser levantadas e discutidas, é que o estudo defende também a subjetividade dos sujeitos, respeitando seus contextos mais diferenciados.

Minayo (2012, p. 622) nos diz que o senso comum se expressa na linguagem, nas atitudes e nas condutas sendo a base do entendimento humano. Dado o seu caráter de expressão das experiências e vivências, logo, o senso comum deve ser levantado nos estudos qualitativos.

Além disso, conforme Minayo (1994) "a pesquisa qualitativa compreende 
o universo de significados, motivos, aspirações, crenças, valores e atitudes e, portanto, não se trata apenas de um conjunto de técnicas, mas de um modo especial de olhar o fenômeno social investigado". Esse universo foi verificado e serviu de aporte nas entrevistas com a reeducandas quando da realização do grupo focal.

Para a investigação utilizou-se como técnica de coleta de dados na abordagem qualitativa o grupo focal, pois, conforme Gatti (2012, p. 9), “o grupo focal permite fazer emergir uma multiplicidade de pontos de vista e processos emocionais pelo próprio contexto de interação criado, permitindo a captação de significados que, com outros meios, poderiam ser difíceis de manifestar".

A abordagem qualitativa nesse estudo também sustentará os resultados obtidos através de gráficos e tabelas; ou seja, mensurará os dados coletados, interpretando-os com base no arcabouço teórico utilizado pela pesquisadora. Dessa forma, na coleta de dados recorreu-se ao questionário com o objetivo de abstrair maior número de informações possíveis, pois esse instrumento foi aplicado com as alunas certificadas nas turmas dos dois primeiros cursos do Programa Mulheres Mil, citados anteriormente.

O questionário é um instrumento importante de coleta de dados. Esse quando bem estruturado e aplicado, é uma ferramenta eficaz e produz respostas com o mínimo de erro. Chagas (2000, p.3) demonstra que "construir um bom questionário depende não só do conhecimento de técnicas, mas principalmente da experiência do pesquisador". Contudo, seguir um método de elaboração é essencial, pois identifica as etapas básicas envolvidas na construção de um instrumento eficaz.

Ressalta-se que deve existir uma sensibilização por parte do pesquisador, em escolher e utilizar o tipo de abordagem que permita a realização de uma investigação mais completa. Bem como que viabilize respostas ao problema levantado no início da pesquisa, compreendendo de maneira mais ampla o fenômeno. Nessa perspectiva Gunther (2006, p.4) explicita:

"Considerando os recursos materiais, temporais e pessoais disponíveis para lidar com uma determinada pergunta científica, coloca-se para o pesquisador e para a sua equipe a tarefa de encontrar e usar a abordagem teórico-metodológica que permita, num mínimo de tempo, chegar a um resultado que melhor contribua para a compreensão do fenômeno e para o avanço do bem-estar social". 


\subsection{CAMPO E SUJEITOS DA PESQUISA}

A pesquisa foi desenvolvida no Núcleo de Ensino do Presidio Feminino, (NUEN), o qual faz parte do Complexo Penitenciário do Distrito Federal, localizado na Cidade do Gama-DF.

A população amostra da pesquisa foi formada por dezesseis reeducandas egressas da primeira e segunda turma dos cursos de Estética Feminina e Recepcionista, ofertados pelo Campus Gama do Instituto Federal de Brasília, no âmbito do Programa Mulheres Mil.

O Campus Gama do IFB foi criado em 2008 por meio da Lei 11.892. Essa unidade oferece formação nas áreas de Logística, Agronegócio, Cooperativismo e Química em nível técnico e Licenciatura em Química em nível superior. A vocação do Campus foi definida por meio de consultas à sociedade e tendo como base dados socioeconômicos da região. São oferecidos cursos Técnicos, Formação Inicial e Continuada (FIC) - que são cursos 'profissionalizantes' de curta duração - projetos de extensão e cursos de idiomas. O campus está situado na DF-480, Lote 01, Setor de Múltiplas Atividades, a implantação dessa unidade no Gama atende, além dessa cidade, as cidades do seu entorno como Recanto das Emas, Riacho Fundo, Riacho Fundo II, Santa Maria, Valparaíso de Goiás e Novo Gama.

A adesão ao Programa Mulheres Mil pelo Campus deu-se em setembro de 2011, quando 100 mulheres foram selecionadas, para o curso básico em Auxiliar de Panificação, as aulas no Campus começaram em 02 de fevereiro de 2012, mas somente em 2013 foram iniciados os cursos no presídio feminino.

A Primeira turma teve início em julho de 2013 e concluiu em dezembro de 2013 e a segunda iniciou em fevereiro de 2014 e concluiu em dezembro de 2014, com a certificação de vinte e sete alunas. As duas turmas perfaziam um total de vinte e sete estudantes, pensava-se que seria possível aplicar os instrumentos de pesquisa a todas elas, por entender que o local onde elas receberam a qualificação do Programa Mulheres Mil, no interior do presídio, seria mais fácil reuni-las.

Ao receber permissão da Vara de Execuções Penais - VEP - para iniciar a pesquisa, contatou-se que só seria possível entrevistar 16 alunas, em função de variados problemas de ordem operacional, enfatizando, principalmente a falta 
de carcereira para acompanhar a pesquisadora nas entrevistas. Havia outras situações que dificultaram a realização da pesquisa no tempo previsto: algumas alunas se encontravam enfermas; outras realizavam atividades laborais da rotina do presídio ou estavam reclusas na "tranca" como é popularmente chamada a cela solitária; outras não concordaram em participar da pesquisa e por fim àquelas que já haviam cumprido pena e estavam fora do presídio e do DF.

Todas as dezesseis reeducandas responderam os questionários, enquanto oito participaram do grupo focal.

Destaca-se que as dificuldades enfrentadas para a realização desta pesquisa, ocorreram especialmente no que tange à burocracia e à morosidade em liberar as autorizações para a entrada no presídio da equipe que inicialmente realizaria o grupo focal. A autorização em tela, demorou três meses para tramitar entre a Vara de Execuções Penais e na Secretaria de Segurança dos Presídios do Distrito Federal - SESIPE - quando enfim foi liberada, haviam contidas nessas autorizações algumas restrições, inclusive as que enfatizavam proibição quanto à gravação de imagens, dessa forma somente as vozes das alunas puderam ser gravadas.

Outro fator negativo para a realização das entrevistas deu-se em face da deflagração de uma greve do Governo do Distrito Federal - GDF-, fato ocorrido no exato período em que estava sendo realizada a pesquisa no presídio, a referida greve, foi aderida pelos agentes penitenciários e carcereiros, dificultando sobremaneira o ingresso e a permanência da pesquisadora no ambiente prisional.

\subsection{PROCEDIMENTOS}

No período consistente entre agosto a outubro de 2014, foi enviado documento à Direção Geral do Campus Gama, solicitando autorização para a realização da pesquisa e utilização das informações sobre o Programa Mulheres Mil e realizadas reuniões com o Coordenador do Programa no Campus, solicitando informações e análise documental, acerca das atividades realizadas pelo programa Mulheres Mil no Presídio Feminino do DF e quando foi relatado a ele o objetivo da pesquisa. Após o consentimento da Direção Geral e o apoio da 
Coordenação, iniciaram-se as primeiras análises e tabulações concernentes aos dados das reeducandas egressas que constavam nos arquivos da Coordenação do Programa.

Em novembro do mesmo ano foram realizadas duas visitas ao presídio feminino, cujo objetivo foi tentar um contato com a direção, para apresentar o Projeto de pesquisa, as intenções e a busca de informações de como proceder para a obtenção dos dados necessários. Realizado o contato com os representantes do Núcleo de Ensino do presídio, conseguiu-se também uma permissão para realizar uma visita às reeducandas egressas do Programa Mulheres Mil. Neste interim foi que se soube que algumas das egressas já haviam deixado o presídio, umas no regime semiaberto e outras por cumprimento de pena.

No mês de maio de 2015, foi feito encaminhamento de documento à Vara de Execuções Penais VEP, e à Secretaria de Segurança Interna dos Presídios SESIPE, apresentando o objetivo do projeto e solicitando permissão para a realização de entrevista, e do grupo focal com as reeducandas. Essa autorização demorou cinco meses para ser liberada com restrições que foram citadas anteriormente.

Antes do início de cada etapa da pesquisa, como questionários, grupo focal, todo o procedimento que seria realizado foi apresentado e discutido com a Coordenadora do NUEN, e posteriormente com as reeducandas que participaram da pesquisa, enfatizando sempre a elas que tudo seria mantido no mais absoluto sigilo, conforme as normas de ética, os questionários foram todos assinados pelas alunas e pela pesquisadora.

\subsection{INSTRUMENTOS PARA LEVANTAMENTO DOS DADOS}

Quanto aos instrumentos que foram utilizados para dar suporte à coleta de dados, destaca-se a investigação teórica dos autores que compõem o referencial teórico e na pesquisa documental, na análise dos questionários socioeconômicos das reeducandas.

Foram feitas também a aplicação do questionário semiestruturado à população-alvo, dezesseis das vinte e sete egressas, e neste havia cinco questões fechadas e sete questões abertas. Essas perguntas foram elaboradas 
com o intuito de coletar as informações relacionadas que contemplassem aos objetivos deste estudo.

De acordo com Marconi e Lakatos (1996, p.100), o questionário é um instrumento de coleta de dados que apresenta várias vantagens, dentre as quais se pode destacar o fato de que este atinge, simultaneamente, um maior número de pessoas, obtendo respostas mais rápidas e mais precisas.

Ao terminar a aplicação dos questionários, oito mulheres foram selecionadas, para comporem o grupo focal,

\begin{abstract}
O grupo focal como um procedimento de coleta de dados é um instrumento no qual o pesquisador tem a possibilidade de ouvir vários sujeitos ao mesmo tempo, além de observar as interações características do processo grupal. Tem como objetivo obter uma variedade de informações, sentimentos, experiências, representações de pequenos grupos acerca de um determinado tema (KIND, 2004).
\end{abstract}

De acordo com Kind (2004), os grupos focais utilizam a interação grupal para produzir dados e insights que seriam dificilmente conseguidos fora do grupo. Esses dados levam em conta o processo do grupo, tomados como maior do que a soma das opiniões, sentimentos e pontos de vista individuais em jogo.

No grupo focal, realizado com as oito reeducandas, como citado anteriormente, não foi permitido gravação de vídeo, apenas da voz das alunas, e cuja moderadora foi a própria pesquisadora, por não haver sido liberada a permissão da entrada no presídio de uma terceira pessoa, entretanto o roteiro foi seguido conforme havia sido elaborado. A gravação do áudio, as conversas e as falas em geral tiveram uma duração total de uma hora e meia. A utilização do grupo focal, nessa pesquisa, foi escolhida porque este instrumento privilegia a fala dos participantes.

Verificou-se, ao fazer as transcrições das gravações, que havia a necessidade de completar os dados que não foram amplamente respondidos, e alguns estavam confusos. Assim, uma semana após a realização do grupo focal, realizou-se mais uma entrevista individualizada com o universo das dezesseis alunas. 


\subsection{TRATAMENTO DOS DADOS}

Com relação aos dados levantados através dos questionários com questões abertas foram analisados com a utilização da técnica de análise de conteúdo que é proposta por BARDIN (1977).

A análise de conteúdo é uma das formas de tratamento de dados em pesquisa bastante utilizada em questões discursivas. Na pesquisa qualitativa sobremaneira, ela busca, de certa forma compreender os discursos dos participantes. Conforme (Bardin, 1977) "Mensagens obscuras que exigem uma interpretação; mensagens com um duplo sentido, cuja significação profunda só pode surgir depois de uma observação cuidadosa ou de intuição carismática. Por detrás do discurso aparente, geralmente simbólico e polissêmico, esconde-se um sentido que convém desvendar".

Na sequência será feita apresentação da base empírica da investigação, cuja análise foi realizada a luz do referencial teórico deste trabalho, o qual foi elaborado a partir do grupo focal, das entrevistas e dos questionários. 


\title{
CAPÍTULO 4
}

\section{DESCRIÇÃO DO CONTEXTO}

\subsection{PRINCÍPIOS DO PROGRAMA MULHERES MIL}

O Programa Mulheres Mil é desenvolvido pelos Institutos Federais de Educação, Ciência e Tecnologia, por meio de parecerias entre diferentes ministérios, ele tem o objetivo de proporcionar às mulheres em condições de vulnerabilidade social, o acesso à educação e à formação profissional e cidadã, com perspectivas de inclusão no mundo do trabalho.

Com essa finalidade, o Programa Mulheres Mil está estruturado em três grandes eixos: Educação, Cidadania e Desenvolvimento Sustentável e, segundo o seu documento base, pretende:

\begin{abstract}
Possibilitar que mulheres moradoras de comunidades com baixo índice de desenvolvimento humano, sem o pleno acesso aos serviços públicos básicos, ou integrantes dos Territórios da Cidadania, tenham uma formação educacional, profissional e tecnológica, que permita sua elevação de escolaridade, emancipação e acesso ao mundo do trabalho, estimulando o empreendedorismo, as formas associativas solidárias e a empregabilidade. (BRASIL, 2011, p. 1).
\end{abstract}

O Programa Mulheres Mil, além dessa formação, que permite às mulheres o acesso ao mundo do trabalho, também pretende proporcionar a elas uma formação humana que fomente sua emancipação e seu empoderamento. $O$ termo empoderamento é advindo da língua inglesa empowermente, que significa "dar poder" a alguém para executar uma tarefa sem precisar de permissão de outrem. Contudo, na concepção de Paulo Freire, esse conceito segue uma lógica diferente, (Freire, 1996) nos diz que a pessoa, grupo ou instituição empoderada, é aquela que realiza por si própria as ações que a levam a se fortalecer e a evoluir.

Por esta razão, a metodologia utilizada no programa Mulheres Mil, firmase na concepção de uma educação como prática de inclusão social, de construção da cidadania e de emancipação dos sujeitos.

Assim, apesar de o Programa Mulheres Mil ser uma política pública de capacitação profissional que em um tempo muito curto se propõe a qualificar profissionalmente, mas não apenas só qualifica para o mercado de trabalho, mas 
aliar essa qualificação a uma formação que possibilite às mulheres se tornarem "sujeitos de sua própria história" (BRASIL, 2011a, p. 27).

É por isso que as mulheres que são atendidas pelo programa não são vistas de maneira descontextualizada, mas, a partir da realidade na qual estão inseridas, visando à formação cidadã e à promoção da equidade, princípio que rege a metodologia dos Colleges Canadenses, na qual o Programa Mulheres Mil está baseado.

O Programa Mulheres Mil é diferente de outros cursos de qualificação, ofertados por outros programas governamentais e/ou sistemas de ensino que apenas preparam o/a trabalhador (a) para o mercado de trabalho, pois oferece uma formação profissional, aliada à elevação da escolaridade, ao combate à violência contra a mulher, à conscientização dos direitos da mulher e sua importância na sociedade, à diminuição das desigualdades de gênero.

Com essa formação profissional aliada à formação cidadã, o programa pretende "promover o crescimento humano das mulheres, por meio da melhoria de suas condições de vida sociocultural e econômica". (BRASIL, 2011a, p. 04). Essa formação que visa ao 'crescimento humano', que tem entre seus objetivos, "fomentar a equidade de gênero, a emancipação e o empoderamento das mulheres" (Ibidem, p. 04), remete à concepção de educação emancipadora de Paulo Freire, a qual forma cidadãos conscientes, autônomos, capazes de observar o mundo e suas contradições, de pensar a realidade na qual estão inseridos e de intervir sobre ela.

Conforme Freire, a educação está intrinsecamente ligada à cidadania, a qual está relacionada ao despertar da consciência crítica, que determina o agir do ser humano no mundo, que o leva a assumir "uma nova postura diante dos problemas de seu tempo e de seu espaço" (FREIRE, 1967, p. 100).

Apesar de o Programa Mulheres Mil visar, primeiramente, à qualificação profissional, é possível perceber, em sua essência, essa concepção de educação transformadora, uma vez que pretende contribuir para que as alunas se tornem "cidadãs, social e economicamente emancipadas". (BRASIL, 2011a, p. 04).

O principal objetivo do acesso, portanto, é viabilizar "o ingresso e a permanência com êxito da população feminina brasileira em situação de vulnerabilidade social nas instituições de educação profissional, buscando sua 
inclusão educativa e sua promoção social e econômica". Para isso, o sistema de acesso deve ser, sobretudo, democrático e inclusivo; deve promover a sustentabilidade e a equidade, independentemente da idade ou nível de escolaridade. (BRASIL, 2011a, p. 5).

Com relação à metodologia utilizada no Programa Mulheres Mil, é mister salientar que ela possui um modelo de ingresso acolhedor e personalizado que pretende reconhecer e respeitar a trajetória de vida das mulheres atendidas por ele, e que principalmente, prevê ações que visem à permanência e ao êxito. Falamos da estrutura física, do apoio técnico, dos recursos, e dos currículos que possibilitem a permanência dessas mulheres nos cursos que são ofertados, as ações que viabilizem o ingresso e permanência das alunas no emprego e empreendimentos, procurando a retomada e continuidade dos estudos como um dos pontos principais pontos do Programa.

O contexto do Programa Mulheres Mil é tratado como um espaço político constituído com a finalidade expressa de integrar os interesses mantidos pelas partes envolvidas, que é o Instituto Federal de Educação, Ciência e Tecnologia de Brasília e os segmentos da sociedade civil. Como pressupostos, os discursos em questão remetem aos objetivos de crescimento e desenvolvimento do Estado, e de emancipação reinserção de mulheres. Com isso, o enfoque dessa realidade social fundamenta-se nos conceitos de gênero (SCOTT, 1990) e o Capital Humano, Investimento em Educação e Pesquisa (SCHULTZ, 1973). É relevante salientar a temática de interface entre gênero e investimento em educação e pesquisa.

\subsection{PROGRAMA MULHERES MIL - O INÍCIO: OS PROJETOS 'PILOTO'}

O Programa Mulheres Mil está inserido no conjunto de prioridades das políticas públicas do Governo do Brasil, especialmente nos eixos promoção da equidade, igualdade entre sexos; combate à violência contra mulher; e acesso à educação. O Programa Nacional Mulheres Mil teve sua origem em um Projeto de cooperação entre o Niágara Colleges do Canadá e o Centro Federal de Educação Tecnológica do Rio Grande do Norte (CEFET/RN) nos anos de 2003 
a 2005. Neste mesmo ano, essa cooperação ampliou-se e passou a envolver outros três CEFETs: Pará, Ceará e Bahia.

Com essa parceria resultou a assinatura da Cooperação Internacional Brasil-Canadá - Promoção de Intercâmbio de Conhecimento para Promoção da Equidade (PIPE) - iniciada em abril de 2007, cujo projeto piloto de duração de quatro anos (2007 a 2010) envolveria treze CEFETs nas regiões Norte e Nordeste do país: Alagoas, Amazonas, Bahia, Ceará, Maranhão, Paraíba, Pernambuco, Piauí, Rio Grande do Norte, Rondônia, Roraima, Sergipe e Tocantins (BRASIL, 2011) (Quadro 1).

O programa também contribuiu para o alcance das Metas do Milênio, promulgada pela ONU em 2000 e aprovada por 191 países. Entre as metas estabelecidas estão a erradicação da extrema pobreza e da fome; a promoção da igualdade entre os sexos; a autonomia das mulheres; e a garantia da sustentabilidade ambiental.

No decorrer do desenvolvimento do projeto piloto, cerca de 1450 mulheres foram beneficiadas pelo projeto Mulheres Mil, e os subprojetos desenvolvidos nesses estados estavam, na sua maioria, relacionados à área de alimentação e governança.

De acordo com o Relatório Mulheres Mil na Rede Federal que foi transformado em um livro intitulado "Caminhos da Inclusão", editado em três idiomas: inglês, português e francês, e organizado pela Jornalista, responsável por todas as publicações do projeto, senhora Estela Rosa em março de 2011, (SETEC/MEC, 2011).

Esse livro traz relatos de 27 alunas e das gestoras dos estados que participaram do projeto bem como de parceiros que colaboraram para que ele tivesse êxito nos treze projetos pilotos, desenvolvidos nos Estados do Norte e Nordeste. Com as narrativas apresentadas no livro, pode-se constatar a força exercida pelo Mulheres Mil no sentido de resgatar a autoestima das mulheres que foram atendidas e também como elas, após as orientações e as competências adquiridas nas aulas práticas e teóricas, nas oficinas e em todas as ações vividas no Mulheres Mil, apresentaram resultados compatíveis com as metas do Milênio. Nas narrativas também, se observa a importância que elas reconhecem por terem ingressado no mercado de trabalho em virtude das qualificações recebidas pelo Programa Mulheres Mil, e enfatizando o 
empoderamento adquirido, sobretudo, destacando a satisfação que elas sentem da grande importância em terem estudado em uma Instituição de Educação Federal de renome como o CEFET.

O livro também relata depoimentos individuais das treze gestoras dos subprojetos desenvolvidos em cada estado, ressaltando o amor, o carinho e a dedicação de cada uma delas para com as alunas, inclusive algumas das gestoras também viveram em vulnerabilidade social, tendo histórico de vida semelhante ao de algumas mulheres que participaram do programa.

Os projetos pilotos desenvolvidos nos treze estados do Norte e Nordeste que foram os pioneiros, a maioria relacionada às áreas de demandas locais que consistiam em alimentação, governança e artesanato são apresentados no Quadro 1. Nesses projetos cerca de 1450 mulheres que se encontravam em vulnerabilidade social foram beneficiadas.

De acordo com os relatos das vinte e sete egressas que constam no livro, todas estavam trabalhando e a maioria delas haviam retomado aos seus estudos, porém esses relatos são concernentes a apenas vinte e sete das 1.450 mulheres certificadas no período. Não se tem conhecimento dos resultados do Projeto Mulheres Mil na vida das outras mulheres beneficiadas. O que se sabe e se tem comprovação é que o Projeto Mulheres Mil, apresentou resultados compatíveis com as metas do milênio para as mulheres, e em função disto se transformou no Programa Nacional Mulheres Mil.

No período de implementação do projeto piloto, e em cooperação com o governo canadense, foram desenvolvidos, "processos, metodologias, ferramentas, técnicas e currículos que promovessem a permanência em sala de aula e a formação em áreas profissionais específicas de cada localidade" (BRASIL, 2011, p. 3). Assim, a metodologia na qual o Programa Mulheres Mil está baseado, teve sua origem na experiência dos colleges canadenses, no trabalho com populações desfavorecidas, visando à promoção da equidade.

A metodologia trazida pelo Canadá é denominada de ARAP, que significa: Avaliação e Reconhecimento de Aprendizagem Prévia. Este modelo "consiste em linhas gerais, em certificar todas as aprendizagens formais ou não formais e proporcionar a qualificação nas áreas necessárias à complementação da qualificação" (Idem, 2011a, p. 3).

No Brasil, esse modelo sofreu algumas alterações positivas, pois ele, 
além de reconhecer os saberes adquiridos ao longo da vida, ainda se oferece uma atenção especial ao acolhimento das mulheres por meio de instrumentos e mecanismos que viabilizem o acesso a uma formação profissional e cidadã, promovendo a elevação da escolaridade, a geração de renda e a inserção no mundo do trabalho.

QUADRO 1 - SUB PROJETOS PILOTOS DESENVOLVIDOS NOS 13 ESTADOS ATENDIDOS PELO PROJETO MULHERES MIL

\begin{tabular}{|c|c|c|c|c|}
\hline ESTADO & PROJETO & $\begin{array}{l}\text { COMUNIDADE } \\
\text { ATENDIDA }\end{array}$ & $\begin{array}{l}\text { MULHERES } \\
\text { BENEFICIADAS }\end{array}$ & $\begin{array}{l}\text { ÁREA DE } \\
\text { FORMAÇÃO }\end{array}$ \\
\hline Alagoas & O Doce Sabor de Ser & $\begin{array}{c}\text { Município de Marechal } \\
\text { Deodoro }\end{array}$ & 80 & Gastronomia \\
\hline Amazonas & $\begin{array}{c}\text { Transformação, Cidadania e } \\
\text { Renda }\end{array}$ & $\begin{array}{l}\text { Área Metropolitana de } \\
\text { Manaus }\end{array}$ & 120 & Governança \\
\hline Bahia & $\begin{array}{l}\text { Mulheres: Um tour em } \\
\text { Novos Horizontes }\end{array}$ & $\begin{array}{l}\text { Comunidade Vila } 2 \text { de } \\
\text { Julho }\end{array}$ & 120 & $\begin{array}{l}\text { Turismo e } \\
\text { Hotelaria }\end{array}$ \\
\hline Ceará & Mulheres de Fortaleza & Bairro de Pirambu & 120 & $\begin{array}{l}\text { Governança e } \\
\text { Gastronomia }\end{array}$ \\
\hline Maranhão & Alimento da Inclusão Social & $\begin{array}{c}\text { Comunidade Vila das } \\
\text { Palmeiras }\end{array}$ & 160 & $\begin{array}{l}\text { Processamento } \\
\text { de Alimentos }\end{array}$ \\
\hline Pará & $\begin{array}{l}\text { Costurando um melhor } \\
\text { amanhã para as mulheres } \\
\text { do Igarapé Mata Fome }\end{array}$ & $\begin{array}{c}\text { Associação Beneficente } \\
\text { Educacional }\end{array}$ & 150 & $\begin{array}{l}\text { Corte Costura e } \\
\text { Informática }\end{array}$ \\
\hline Paraíba & $\begin{array}{c}\text { Beneficiamento e } \\
\text { Transformação do Pescado }\end{array}$ & Bayeux e Cabedelo & 160 & $\begin{array}{l}\text { Processamento } \\
\text { de Pescado e } \\
\text { Artesanato }\end{array}$ \\
\hline Pernambuco & $\begin{array}{l}\text { Mulher Pernambucana em } \\
\text { Primeiro Lugar }\end{array}$ & Recife & 120 & $\begin{array}{l}\text { Artesanato, } \\
\text { Gastronomia e } \\
\text { Informática }\end{array}$ \\
\hline Piauí & Vestindo a Cidadania & $\begin{array}{c}\text { Vila Verde Lara, Cidade } \\
\text { Leste - Teresina }\end{array}$ & 60 & $\begin{array}{l}\text { Corte Costura e } \\
\text { Confecção }\end{array}$ \\
\hline $\begin{array}{l}\text { Rio Grande do } \\
\text { Norte }\end{array}$ & Casa da Tilápia & $\begin{array}{l}\text { Assentamentos do } \\
\text { Território do Mato } \\
\text { Grosso }\end{array}$ & 120 & $\begin{array}{l}\text { Beneficiamento } \\
\text { do Couro da } \\
\text { Tilápia }\end{array}$ \\
\hline Roraima & Inclusão com Educação & $\begin{array}{c}\text { Reeducandas da } \\
\text { Penitenciária Agrícola do } \\
\text { Monte Cristo }\end{array}$ & 80 & $\begin{array}{l}\text { Gastronomia, } \\
\text { Processamento } \\
\text { de Alimentos e } \\
\text { Informática }\end{array}$ \\
\hline Sergipe & Do Lixo a Cidadania & Bairro Santa Maria & 80 & $\begin{array}{l}\text { Reciclagem de } \\
\text { Resíduos Sólidos } \\
\text { e Artesanato }\end{array}$ \\
\hline Tocantins & $\begin{array}{c}\text { Construindo a Cidadania } \\
\text { Através da Arte }\end{array}$ & $\begin{array}{l}\text { Distrito do Taquaruçú- } \\
\text { Palmas }\end{array}$ & 80 & $\begin{array}{c}\text { Bio artes, } \\
\text { Pinturas de tela, } \\
\text { Artesanato com } \\
\text { Produtos } \\
\text { Naturais. }\end{array}$ \\
\hline
\end{tabular}

Fonte: Este quadro foi elaborado com base nos dados do site: http://portal.mec.gov.br

Esse modelo também prevê o acompanhamento das egressas e dos 
impactos gerados na família das participantes e na comunidade respectiva.

O Projeto Mulheres Mil foi desenhado a partir da observância das diretrizes do governo brasileiro em torno da redução da desigualdade social e econômica de populações marginalizadas e do compromisso do país com a defesa da igualdade de gênero. (BRASIL, 2011)

O Governo brasileiro, com base no sucesso alcançado pelo projeto piloto Mulheres Mil, decidiu, por meio do Ministério da Educação e Cultura e da Secretaria de Educação Profissional e Tecnológica SETEC, institucionalizar o projeto, que passou a ser um programa nacional integrante do Plano Brasil sem Miséria. Instituído pela Portaria $\mathrm{n}^{\circ} 1.015$, de 21 de julho de 2011, e teve a perspectiva de atingir 100 mil mulheres até 2014 .

Da rápida noção, e concluindo, o programa está estruturado em três eixos: Educação, cidadania e desenvolvimento sustentável - o programa possibilitará a inclusão social, por meio da oferta de formação focada na autonomia e na criação de alternativas para a inserção no mundo do trabalho, para que essas mulheres consigam melhorar a qualidade de suas vidas e das de suas comunidades. Segundo a Secretaria de Educação Profissional e Tecnológica (SETEC) do Ministério da Educação e Cultura (MEC), tem-se como meta expandir o programa para outras regiões do país, visando transformá-lo em uma política pública a ser implementada em todos os Institutos Federais de Educação, Ciência e Tecnologia do país, ampliando a oferta para as mulheres desfavorecidas do Brasil.

O que já se constata na atualidade, por exemplo, o IFB já incorporou o programa e desenvolve, desde 2013, ações para o alcance dos objetivos do programa, cita-se a recente atuação de Execução dos Trabalhos de Formação Inicial e Continuada, (FIC) no Complexo Penitenciário Feminino do Distrito Federal, objeto de exame, analise e investigação deste trabalho.

\subsection{O PROGRAMA MULHERES MIL NO IFB}

\subsubsection{CRIAÇÃO DO INSTITUTO FEDERAL DE BRASÍLIA - IFB}

O IFB foi criado em 2008, por meio da Lei $n^{0} 11.892$, é uma instituição de educação superior, básica e profissional, pluricurricular e multicampi, 
especializada na oferta de educação profissional e tecnológica nas diferentes modalidades de ensino, com base na conjugação de conhecimentos técnicos e tecnológicos, com as suas práticas pedagógicas. Possui dez campi, distribuídos nas cidades administrativas do Distrito Federal: Campus Brasília, Ceilândia, Estrutural, Gama, Planaltina, Riacho Fundo, Samambaia, São Sebastião, Taguatinga e Taguatinga Centro.

Essa mesma Lei institui a Rede Federal de Educação Profissional, Científica e Tecnológica, cria os Institutos Federais de Educação, Ciência e Tecnologia que têm por finalidade e características "ofertar educação profissional e tecnológica, em todos os seus níveis e modalidades, formando e qualificando cidadãos com vistas na atuação profissional nos diversos setores da economia, com ênfase no desenvolvimento socioeconômico local, regional e nacional". Nesse contexto:

\footnotetext{
A educação profissional e tecnológica surge como processo educativo e investigativo de soluções técnicas e tecnológicas às demandas sociais e peculiaridades regionais." Uma característica marcante deste modelo de educação é a verticalização dos itinerários formativos, tornando mais eficiente o uso da infraestrutura física e dos quadros de pessoal. (Lei $n^{\circ} 11.892$, de 2008).
}

De acordo com o PDI - Plano de Desenvolvimento Institucional 20142018 do IFB, o histórico da implantação e desenvolvimento da Instituição remonta à criação da Escola Técnica de Brasília, que se inicia em 17 de fevereiro de 1959 através do Plano de Metas do Governo do Presidente Juscelino Kubitschek (Lei n 3.552, de 1959 e Exposição de Motivos nº 95 - DOU de 19/02/59). A Escola Agrotécnica de Brasília foi inaugurada em 21 de abril de 1962, subordinada à Superintendência do Ensino Agrícola e Veterinário do Ministério da Agricultura. Pelo Decreto n 53.558, de 1964, em consonância com a Lei de Diretrizes e Bases da Educação, ficou estabelecida a integração da Escola de Didática do Ensino Agrícola ao Colégio, passando a Escola Agrotécnica a denominar-se Colégio Agrícola de Aplicação de Brasília. No ano de 1967 o Decreto n 60.731, determinou a subordinação das Escolas Agrícolas do Ministério da Agricultura ao Ministério da Educação e Cultura. Com a extinção da Escola de Didática do Ensino Agrário, o colégio de aplicação voltou a ter a denominação anterior de Colégio Agrícola de Brasília. 
A partir da década de 1980, diante de um novo cenário econômico e produtivo, com o desenvolvimento de novas tecnologias, agregadas à produção e à prestação de serviços, as instituições de educação profissional vêm buscando diversificar programas e cursos para elevar os níveis da qualidade da oferta e atender as demandas da sociedade.

\subsubsection{O CAMPUS GAMA}

O Campus Gama do IFB foi criado em 2008 por meio da Lei 11.892. Esta unidade oferece formação nas áreas de Logística, Agronegócio, Cooperativismo e Química em nível técnico e Licenciatura em Química em nível superior. A vocação do Campus foi definida através de consultas à sociedade e tendo como base dados socioeconômicos da região. São oferecidos cursos Técnicos, Formação Inicial e Continuada (FIC) - que são cursos 'profissionalizantes' de

curta duração - projetos de extensão e cursos de idiomas. O campus está situado na DF-480, Lote 01, Setor de Múltiplas Atividades. A implantação dessa unidade no Gama atende, além dessa cidade, as cidades do seu entorno como Recanto das Emas, Riacho Fundo, Riacho Fundo II, Santa Maria, Valparaíso de Goiás e Novo Gama.

\subsubsection{O PROGRAMA MULHERES MIL NO IFB}

No IFB, não houve adesão ao Programa Mulheres Mil por parte de nenhum de seus Campi na primeira chamada, que ocorreu em 2011, na segunda em 2012, houve duas adesões por parte dos campi Gama e Taguatinga Centro. Depois, em 2013, foram contemplados os campi Taguatinga, Planaltina, Ceilândia e Riacho Fundo.

Atualmente no IFB existem dez campi, destes, seis desenvolvem cursos no âmbito do Programa (Quadro 2). Os Campi Brasília, Estrutural, Samambaia e São Sebastião ainda não aderiram ao programa. 
QUADRO 2: Cursos ofertados nos Campi do IFB

\begin{tabular}{|c|l|}
\hline Campi- IFB & \multicolumn{1}{|c|}{ CURSOS } \\
\hline $\begin{array}{c}\text { Taguatinga } \\
\text { Centro }\end{array}$ & Empreendedorismo com ênfase em Alfabetização \\
\cline { 2 - 2 } & Atendimento ao Cliente \\
\cline { 2 - 2 } & Técnicas de Secretariado \\
\hline Gama & $\begin{array}{l}\text { Estética Feminina - Trança Afro } \\
\text { Recepcionista } \\
\text { Panificação }\end{array}$ \\
\hline Riacho Fundo & Cuidador de Idosos \\
\hline Taguatinga & Doceira \\
\hline Planaltina & Artesanato e Resíduos sólidos \\
\hline Fonte: Quadro elaborado com base nos dados dos campi do IFB.
\end{tabular}

Desde fevereiro de 2012 o Campus Gama oferta cursos no âmbito do Programa Mulheres Mil, entretanto, somente no segundo semestre de 2013 é que foi ofertado no PFDF o Curso de Estética Feminina e em 2014.1 o Curso de Recepcionista, este já no âmbito do PRONATEC/BSM:

[...] O MDS e o MEC firmaram parceria para integrar o Pronatec/BSM ao Programa Mulheres Mil, desenvolvido desde 2007 pelos Institutos Federais de Educação, Ciência e Tecnologia em cooperação com o governo do Canadá. Essa integração dos programas buscou ampliar a oferta de qualificação profissional às mulheres mais pobres, em especial às beneficiárias do programa Bolsa Família que não acessavam os cursos do Pronatec, com baixa escolaridade e em situação de vulnerabilidade social (Ministério do Desenvolvimento Social e Combate à Fome, 2015, p.63)

Este estudo se propõe a verificar as contribuições do Programa Mulheres Mil na vida das reeducandas do Presidio Feminino do Distrito Federal com base nas diretrizes do programa, bem como nas metas que ele pretende alcançar, especialmente no que tange ao combate da feminização da pobreza, à promoção da igualdade de gênero e a promoção e geração de renda às mulheres egressas que foram beneficiadas no período de 2013.2 a 2014.1 .

\subsubsection{A EXPERIÊNCIA DO PROGRAMA MULHERES MIL NO CAMPUS GAMA}

A adesão ao Programa Mulheres Mil pelo Campus deu-se em setembro de 2012, quando 100 mulheres foram selecionadas, para o curso básico em 
Auxiliar de Panificação, as aulas no Campus tiveram início em 02 de fevereiro de 2012 as mulheres da comunidade e do entorno. No presídio feminino, em 2013, foram oferecidos os cursos de Estética Feminina e posteriormente o de Recepcionista, objeto da pesquisa, como veremos a seguir.

Com base nos direitos à educação e pela necessidade de inserção e ressocialização das pessoas privadas de liberdade, o Instituto Federal de Educação de Brasília - IFB/Campus Gama, implantou no segundo semestre de 2013 uma ação de educação na Penitenciária Feminina do Distrito Federal, conhecida como "Colméia" onde cumpriam pena, na época 583 mulheres, esta ação ocorreu por meio do Programa Mulheres Mil, do Ministério da Educação e Cultura, com a oferta do curso de Artesanato e Estética Feminina.

O objetivo foi oportunizar qualificação profissional a 25 internas em regime fechado, mas também possibilitar às mulheres um novo olhar sobre suas atitudes diante da vida a fim de se perceberem como pessoas e na relação com o outro, a lado da possibilidade de fortalecimento da identidade, com foco nas questões de gênero e raça.

O público selecionado para participar do curso teve como prioridade as mulheres negras e pardas, sendo estabelecido tal critério em edital de seleção das alunas, ao lado de critérios como a baixa escolaridade, número de filhos e a reincidência no cumprimento de penas.

Com base nestes critérios, o grupo participante teve a seguinte predominância: quanto à cor da pele $60 \%$ pardas, $37 \%$ negras; quanto à escolaridade $70 \%$ com fundamental incompleto; quanto à reincidência no cumprimento de penas $37 \%$ reingresso mais de duas vezes, $23 \%$ reingresso até duas vezes.

Juntamente às aulas de artesanato e trança em cabelo de mulher negra foram oferecidas aulas de informática, comunicação oral e escrita, biodança e educação financeira, num total de 160 horas de aula. O esforço metodológico foi o de fortalecer o pensamento crítico e a capacidade de intervenção nas aulas expositivas e dialogadas, incentivando os exercícios práticos.

Foram vinte e cinco mulheres, na primeira turma, e vinte e sete na segunda. Estas alunas cumprem pena em regime fechado, um dos critérios facilitadores para a execução do programa no interior do presídio, pois as aulas são todas ministradas neste local. 
Especificamente no IFB, Campus Gama, o programa objetiva, sensibilizar e fortalecer a equipe multidisciplinar para atuar no Presídio Feminino, com vistas a promover por meio de atividades diferenciadas, o acesso desse público específico, ao mundo do trabalho e ainda Viabilizar a elevação de Escolaridade por meio de resultados obtidos no diagnóstico da comunidade por meio da metodologia própria - Acesso, Permanência e Êxito - essa metodologia prevê o reconhecimento de saberes, considerando que as mulheres são sujeitos de direitos e que todas as aprendizagens formais ou não formais que elas venham a ter proporcionarão a qualificação nas áreas necessárias à complementação de seus saberes e conhecimentos já adquiridos; Visa também fazer a Certificação de Saberes e Competências; fomentar o desenvolvimento de cursos de formação humana e profissional alinhados ao contexto social junto à comunidade interna e externa.

Durante a permanência no programa, as mulheres desenvolvem diversas atividades, tais como: oficinas; dinâmicas de grupos; mapa da vida; círculos de estudo, debates, palestras, filmes e seminários acerca de temas como: cidadania, direitos da mulher, saúde, meio ambiente e outros; oficinas profissionalizantes; registros e análises fotográficos; elaboração de portfólios.

Desta forma o Programa Mulheres Mil tem auxiliado na melhoria da qualidade de vida das mulheres consideradas em situação de vulnerabilidade social devido à oferta de cursos profissionalizantes em todo o país. De maneira educativa, as mulheres são inseridas no mercado de trabalho.

Os cursos profissionalizantes ofertados às reeducandas do complexo penitenciário do Distrito Federal, por meio do Programa Mulheres Mil, contribuem para que estas mulheres fiquem mais satisfeitas, melhorem sua autoestima, vislumbrem novas expectativas de vida com vistas a sua reinserção no mundo do trabalho e consequentemente a geração de renda para si e seus familiares, pois educação é o pressuposto do desenvolvimento econômico, bem como do desenvolvimento do indivíduo, a educação é um instrumento imprescindível para que o ser humano possa reconhecer-se a si próprio como agente ativo na modificação da mentalidade de seu grupo e ser promotor de ideais. Segundo Shultz (1973, p.14), O investimento no homem pode aumentar tanto as suas satisfações quanto os serviços produtivos, que são a sua contribuição quando trabalha $[\ldots]$ 
O trabalho humano, quando qualificado por meio da educação, é um dos mais importantes meios para a ampliação da produtividade econômica, e, portanto, das taxas de lucro do capital. Neste sentido, ele nos diz que o componente da produção que decorre da instrução é um investimento em habilidades e conhecimentos, que aumenta as rendas futuras semelhante a qualquer outro investimento em bens e produção. (SHULTZ, 1973).

De acordo com Rigotto (2006), quanto mais o indivíduo se instrui maior é a valorização do profissional e sua ascensão e consequentemente melhor a sua qualidade de vida e de seus familiares.

Na perspectiva do capital humano, quanto melhor o nível de escolaridade maior é a renda futura. Em relação às mulheres e ao crescimento demográfico, Rigotto (2006) afirma que mulheres com maior grau de instrução têm menos filhos.

Segundo loschpe (apud RIGOTTO, 2006, p. 392) "a educação brasileira mostrou que o país deve com urgência empenhar-se na diminuição das desigualdades sociais e educacionais, para alcançar maior nível de desenvolvimento econômico e em um futuro não tão distante.

\subsection{CONTEXTO SÓCIOECONÔMICO DA CIDADE ADMINISTRATIVA DO GAMA-DF}

Com vistas a conhecer melhor a realidade onde se situa o local da pesquisa deste estudo é mister apresentar algumas especificidades das cidades administrativas do Distrito Federal, com ênfase na cidade do Gama, onde está localizado o Presídio Feminino.

A divisão política do Distrito Federal consiste em regiões administrativas, conforme foi estabelecido pela Lei $n^{\circ} 4.545 / 64$. Essas regiões administrativas, que também são conhecidas como cidades-satélites, são unidades de divisão territorial e de divisão administrativa, cujos limites físicos, estabelecidos pelo poder público, definem a jurisdição da ação governamental para fins de descentralização administrativa e coordenação dos serviços públicos de 
natureza local.

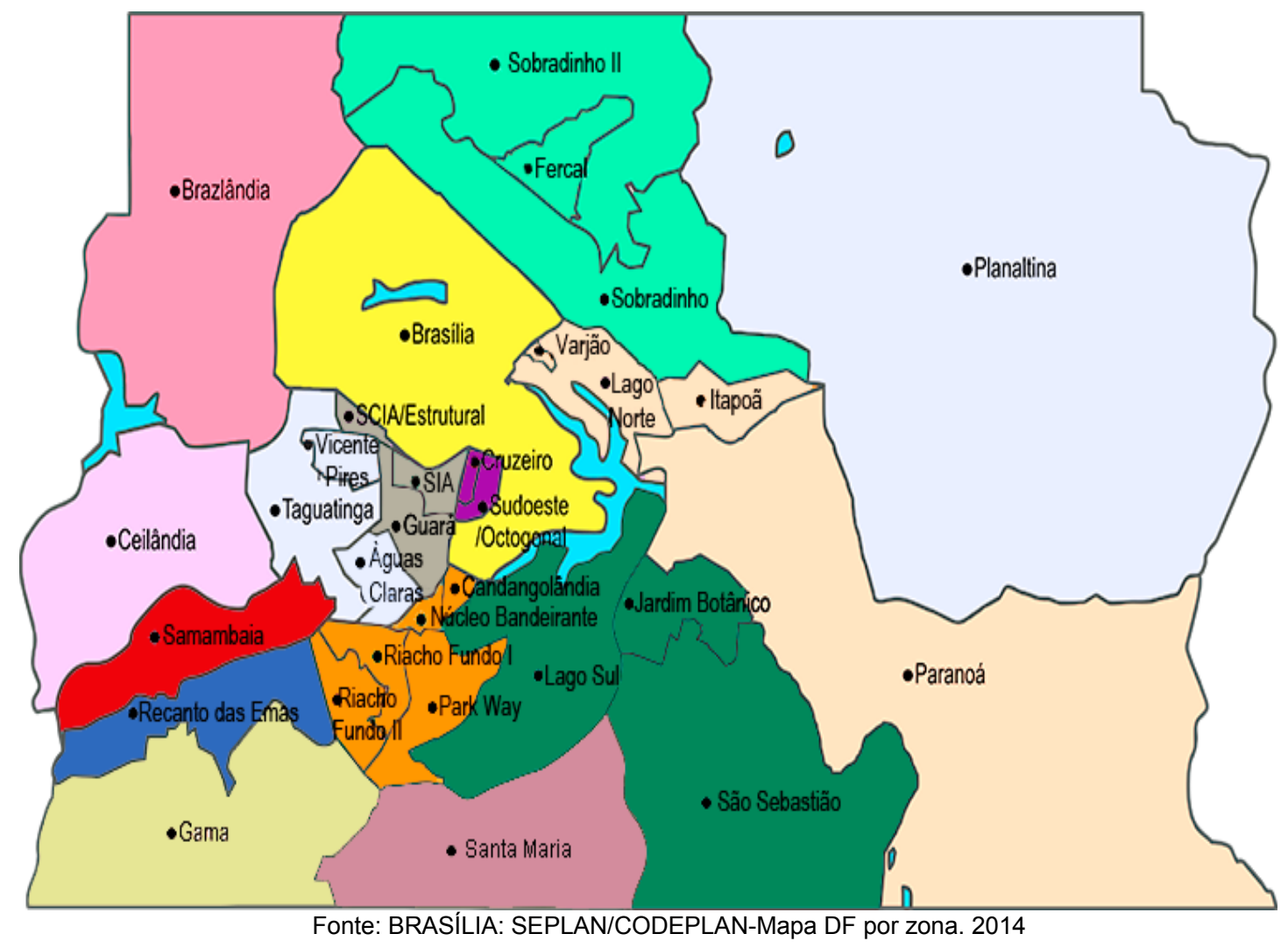

Conforme estudo, realizado pela Companhia de Planejamento do Distrito Federal (Codeplan), na Cidade administrativa do Gama, 31 mil moradores têm entre 0 e 18 anos. Do total de habitantes, quase metade está na faixa etária de 25 a 59 anos. De acordo com o levantamento, quase todos os domicílios estão em ruas asfaltadas e com iluminação pública, calçadas, meios-fios, rede de águas pluviais, abastecimento de água pela rede geral e fornecimento de energia elétrica. O levantamento considera que o Gama é uma região com renda média baixa, com aumento de posse de bens e serviços como televisão por assinatura e automóveis.

\subsection{O SISTEMA PRISIONAL FEMININO NO DISTRITO FEDERAL}

A Subsecretaria do Sistema Penitenciário - SESIPE, unidade gestora e coordenadora do Sistema Prisional do DF, diretamente subordinada à Secretária de Estado de Segurança Pública e Defesa Social, é composta pelas seguintes 
unidades prisionais: Centro de Detenção Provisória - CDP; Centro de Internamento e Reeducação - CIR; Penitenciária do Distrito Federal I - PDF I; Penitenciária do Distrito Federal II - PDF II; Penitenciária Feminina do Distrito Federal - PFDF; Centro de Progressão Penitenciária - CPP e Diretoria Penitenciária de Operações Especiais - DPOE.

O PFDF - Presídio Feminino do Distrito Federal popularmente conhecido como Colméia, local da pesquisa deste estudo, está situado no Setor de Chácaras da região administrativa do Gama, no Distrito Federal. Esse presídio está destinado ao recolhimento de mulheres, sentenciadas ao cumprimento de pena privativa de liberdade, nos regimes Semiaberto e fechado, bem como de presas provisórias, que aguardam julgamento pelo Poder Judiciário.

\subsubsection{CARACTERÍSTICAS DO PRESÍDIO FEMININO DO DISTRITO FEDERAL}

A Penitenciária Feminina do Distrito Federal - PFDF é um estabelecimento prisional de segurança média destinado ao recolhimento de sentenciadas a cumprimento de pena privativa de liberdade em regime fechado e semiaberto, bem como de presas provisórias que aguardam julgamento pelo Poder Judiciário.

Em caráter excepcional e em casos previamente analisados pela Vara de Execuções Penais, abriga presas provisórias federais. Possui blocos separados para as internas em prisão provisória, regime semiaberto e fechado. Apresenta oficinas, salas de aula e biblioteca. Existe ala para gestantes e para lactantes, que permanecem com os bebês, até, pelo menos, os seis meses de idade. Há assistência médica (clínica geral e psiquiatria), psicológica e odontológica.

Na penitenciária encontra-se a Ala de Tratamento Psiquiátrico (ATP) com enfermaria, farmácia e consultório médico. Conta com psiquiatra, psicólogos e terapeutas ocupacionais onde são desenvolvidas atividades de terapia, tais como cultivo de horta e oficina de reciclagem de papel.

Com relação ao trabalho e estudo, a PFDF possui internas matriculadas no núcleo de ensino - da alfabetização ao ensino médio, no IFB (Instituto Federal Brasileiro) e em cursos profissionalizantes. E ainda ocorrem rotineiramente 
diversos cursos, tais como: curso de recepcionista, curso de maquiagem, empreendedorismo, massagem, entre outros.

$\mathrm{Na}$ área de segurança, a PFDF conta com dois equipamentos "body scanner" de alta tecnologia. Além de humanizar os procedimentos de revista pessoal, inibem a entrada de objetos ou substâncias entorpecentes que afrontam a segurança prisional. A Unidade conta também com outros sistemas de segurança instalados em pontos estratégicos, que contribuem para que o estabelecimento funcione de forma satisfatória.

As Políticas Públicas, nas quais se insere o Programa Mulheres Mil Função dos IFs: a relação do Programa com a proposta dos IFs. - O Programa no IFB/Campus Gama - Capital Humano, Qualificação Profissional - Mundo do Trabalho, Reinserção Social, Mulheres Privadas de Liberdade e Sistema Prisional, foi a sequência apresentada que constituiu a resenha da literatura deste estudo

\subsection{PROGRAMA MULHERES MIL NO SISTEMA PRISIONAL BRASILEIRO}

Desde a sua concepção, em 2007 o programa Mulheres Mil já preconizava a redução da desigualdade social e econômica de populações marginalizadas, além do compromisso do país com a defesa da igualdade de gênero. Para tanto o Brasil desenvolveu parcerias com as instituições nacionais e estrangeiras na elaboração e execução de treze projetos pilotos. Entre os quais, o Estado de Roraima no Complexo Prisional do Monte Cristo, onde se localiza a Penitenciária Agrícola Pública Feminina, popularmente conhecida na capital de Boa Vista como PA.

Com a institucionalização do Programa Mulheres Mil e a adesão ao Pronatec/BSM, outros estados passaram a desenvolver o programa no âmbito do sistema prisional, é o caso dos Estados do Amapá, Maranhão, Santa Catarina, Rio Grande do Sul, Mato Grosso, Tocantins, Goiás, Rondônia e do Distrito Federal. 


\section{CAPÍTULO 5}

\section{ANÁLISE dOS RESULTADOS DA PESQUISA DE CAMPO}

As informações abstraídas da abordagem qualitativa, bem como os dados coletados com o uso do questionário foram tabulados e apresentados em gráficos, com o aporte do programa Excel.

As informações obtidas por meio dos questionários e as gravações do grupo focal geraram relatório. As gravações foram ouvidas e transcritas. A análise foi realizada baseada na técnica de análise de conteúdo eleita para essa pesquisa, descrita anteriormente. Quanto ao procedimento, utilizou-se o mesmo das questões discursivas do questionário semiestruturado.

Para o relato dos resultados utilizou-se a narração e a descrição.

Para a compreensão do objetivo deste estudo, que é demonstrar quais as contribuições do Programa Mulheres Mil do IFB, Campus Gama, na vida das vinte e sete reeducandas do presídio feminino do Distrito Federal, egressas dos Cursos de Estética Feminina, 2013 e Recepcionista, em 2014, foi realizada a tabulação e análise de dados de questionários semiestruturado, preenchido por elas. Como já havia sido previsto na metodologia, as perguntas foram relativas ao perfil socioeconômico e cultural fazendo relação do antes e depois da formação recebida pelo Programa.

Com base nas falas das reeducandas as categorias foram preestabelecidas e as subcategorias foram criadas, conforme os temas surgiam e também de acordo com o número das ocorrências. As categorias são: As Consequências do Programa para a Ressocialização, Qualificação e Geração de Renda. Essas Classes Temáticas, as Categorias e as Subcategorias estão demonstradas a seguir no Quadro 3. 
QUADRO 3 - RESULTADOS DA PESQUISA

\begin{tabular}{|c|c|c|}
\hline Classes Temáticas & Categorias & Subcategorias \\
\hline \multirow[t]{3}{*}{$\begin{array}{l}\text { Perfil } \\
\text { socioeconômico }\end{array}$} & \multirow{3}{*}{$\begin{array}{ll}\text { Antes } & \text { da } \\
\text { Certificação } & \\
\text { Após } & \text { a } \\
\text { Certificação } & \end{array}$} & a) Família (estado civil, filhos) \\
\hline & & b) Ocupação/Trabalho \\
\hline & & c) Renda familiar \\
\hline \multirow[t]{2}{*}{ Qualificação } & \multirow{2}{*}{$\begin{array}{ll}\text { Inserção } & \text { no } \\
\text { mercado } & \text { de } \\
\text { trabalho } & \end{array}$} & a) Empregabilidade \\
\hline & & b) Oportunidades de atuação na área da qualificação \\
\hline \multirow[t]{2}{*}{ Autoestima } & \multirow[t]{2}{*}{ Contribuições } & $\begin{array}{l}\text { a) Valorização pessoal/ Sonhos/Autoestima } \\
\text { elevada/Relaçâo interpessoal/Sociabilidade }\end{array}$ \\
\hline & & b) Consciência dos direitos e deveres \\
\hline \multirow[t]{3}{*}{$\begin{array}{l}\text { Percepção geral } \\
\text { do programa }\end{array}$} & \multirow{3}{*}{$\begin{array}{l}\text { Atributos } \\
\text { positivos } \\
\text { negativos }\end{array}$} & a) Curso ofertado/Curso esperado \\
\hline & & b) Estrutura (professores, equipamentos, lanche...) \\
\hline & & c) Aulas teóricas e práticas \\
\hline
\end{tabular}

O Programa Mulheres Mil é direcionado às mulheres que se encontram na faixa etária a partir dos 16 anos, porém por se tratar de um público diferenciado, as reeducandas do Presídio Feminino do Distrito Federal, as beneficiárias investigadas do programa têm idade acima de dezoito anos; uma vez que atendem ao critério exigido por lei. Dessa forma, a maioria das reeducandas está na faixa etária entre vinte e seis e trinta e três anos de idade, correspondendo a seis mulheres (Gráfico 1).

Quanto à escolarização, metade delas concluiu o ensino fundamental, oito possuem o ensino fundamental completo e apenas uma não concluiu o ensino médio, destaca-se ainda uma que possui o ensino superior incompleto (Gráfico 3).

Com relação ao número de filhos, seis delas disseram ter de um a três filhos, quatro responderam ter de quatro a seis, duas não possuem e uma disse ter oito filhos (Gráfico 4). 
Antes de ingressarem na PFDF as reeducandas relataram exercer as seguintes profissões: estudantes, donas de casa, empregada doméstica, dançarina, caixa de supermercado e agricultora. Quando perguntadas sobre qual a profissão que gostariam de exercer depois de cumprirem as penas, a maioria pretende ser recepcionista, cabeleireira, manicure ou depiladora. Outras profissões indicadas por elas foram: cozinheira, trabalhar com informática, confecção de moda íntima e gerenciar o próprio negócio. Ressalta-se que em função da peculiaridade, o diferencial do local onde o curso foi desenvolvido, não havia mulheres com idade abaixo de dezoito anos. O percentual apresentado nos leva a discutir assuntos pertinentes e relativos ao contexto global, no que se refere à educação e também a elementos específicos da realidade das participantes do estudo.

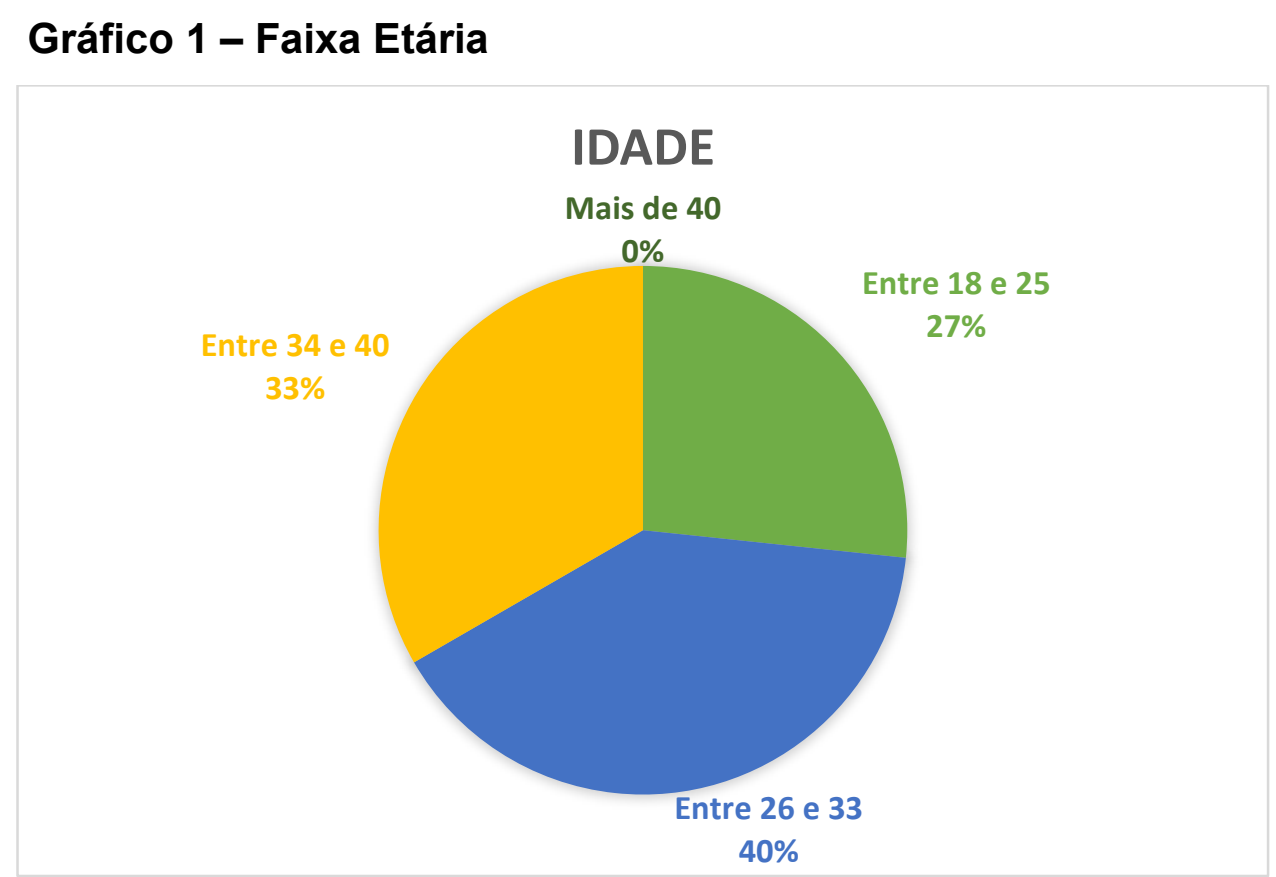

Fonte: Dados da pesquisa, 2015

De acordo com o gráfico acima, percebe-se que as reeducandas egressas do Programa Mulheres Mil tem idade acima de dezoito anos; conforme o critério exigido por lei. Dessa forma, a grande maioria das reeducandas está na faixa etária entre 18 e 35 anos de idade.

Observa-se que o Programa Mulheres Mil atende ao objetivo de englobar uma fase da vida mais extensa, não limitando a participação de mulheres que se enquadram em fases de vida diferentes. Diante disso, o público atendido pelo 
programa é bem variado quanto à idade.

Percebe-se que o crescimento das políticas públicas sociais e educacionais tem oportunizado a participação das mulheres em cursos de capacitação, objetivando a elevação da escolaridade, a melhora da autoestima, a socialização, o empoderamento, a produtividade, o emprego e sua inserção no mundo do trabalho. Nesse aspecto Programa Mulheres Mil é uma referência, pois ele apresenta e desenvolve atividades para atender ao público feminino carente, em vulnerabilidade social e que, por algum motivo, teve seus estudos interrompidos, ou que não conseguiu acesso à escolaridade ou até mesmo à alfabetização, incluindo as reeducandas do sistema prisional brasileiro.

Ao promover a formação educacional, profissional e cidadã de mulheres pobres em situação de maior vulnerabilidade, o Programa Mulheres Mil cria pontes necessárias para lapidar seu potencial produtivo na perspectiva de melhorar as condições de suas vidas, famílias e comunidades. Ampliar a oferta de cursos de profissionalização articulados com elevação de escolaridade, especialmente para mulheres em situação de vulnerabilidade social, atendendo à 100 mil mulheres. (BRASIL, 2014, p. 3)

Umas das metas do Plano Nacional de Políticas para as Mulheres é ampliar a oferta de cursos de profissionalização articulados com elevação de escolaridade, especialmente para mulheres em situação de vulnerabilidade social, atendendo à 100 mil mulheres entre 2013 e 2015. Com base nisso o IFB, Campus Gama, elaborou e desenvolveu dois cursos, por meio do Programa Mulheres Mil no PFDF, ofertado à 27 reeducandas, entre os anos de 2013 e 2014.

As mulheres em vulnerabilidade social são as pertencentes a esse grupo de indivíduos, o qual muitas vezes não apresentam condições reais de continuar os estudos. A condição financeira dos indivíduos exerce influência direta no abandono escolar; pois muitas vezes a renúncia aos estudos acontece devido às necessidades materiais manifestadas e também mediante as horas exigidas no trabalho. Diante disso, muitas mulheres abandonam seus estudos para manterem materialmente suas famílias. Ferro; Lopes e Pontilli (2013, p.1) relatam que "[...] frequentemente, as pessoas com baixa qualificação começaram sua vida laboral ainda na fase infanto-juvenil e por isso foram obrigados a sacrificar seus estudos". 


\section{Gráfico 2 - Estado Civil}

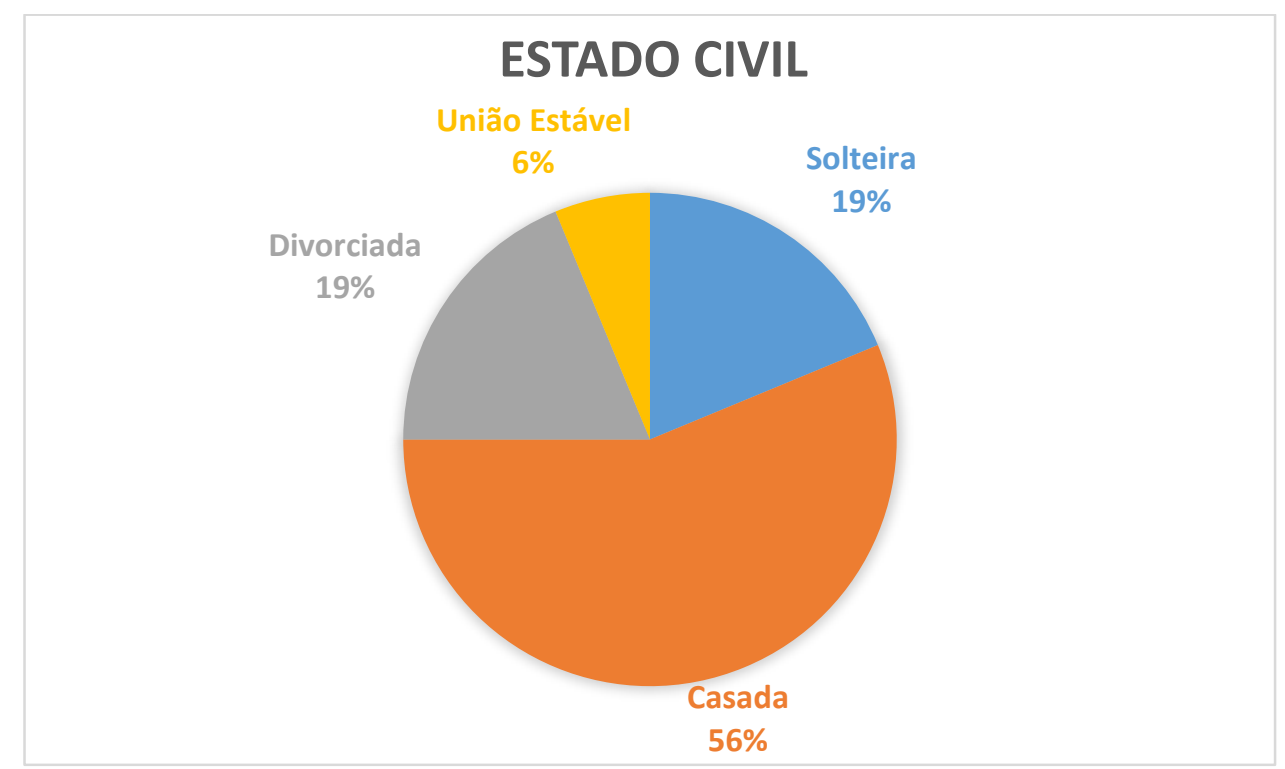

Fonte: Dados da pesquisa, 2015

Com relação à situação civil, nove mulheres se declararam casadas, três disseram ser solteiras, uma possui uma união estável e três afirmaram ser divorciadas. Todavia, dentre as que se declararam solteiras, muitas tinham companheiro com os quais residiam antes de serem detidas, e os mesmos se encontravam reclusos também no presídio masculino, e elas, optaram por essas respostas por não estarem oficialmente casadas. Mesmo que esse dado não conste no gráfico acima, o contato com as mulheres reeducandas, favorece a essa observação no momento da aplicação do questionário, e a confiança que muitas delas expressam ter com o entrevistador, nos dão esta certeza. 


\section{Gráfico 3 - Escolaridade}

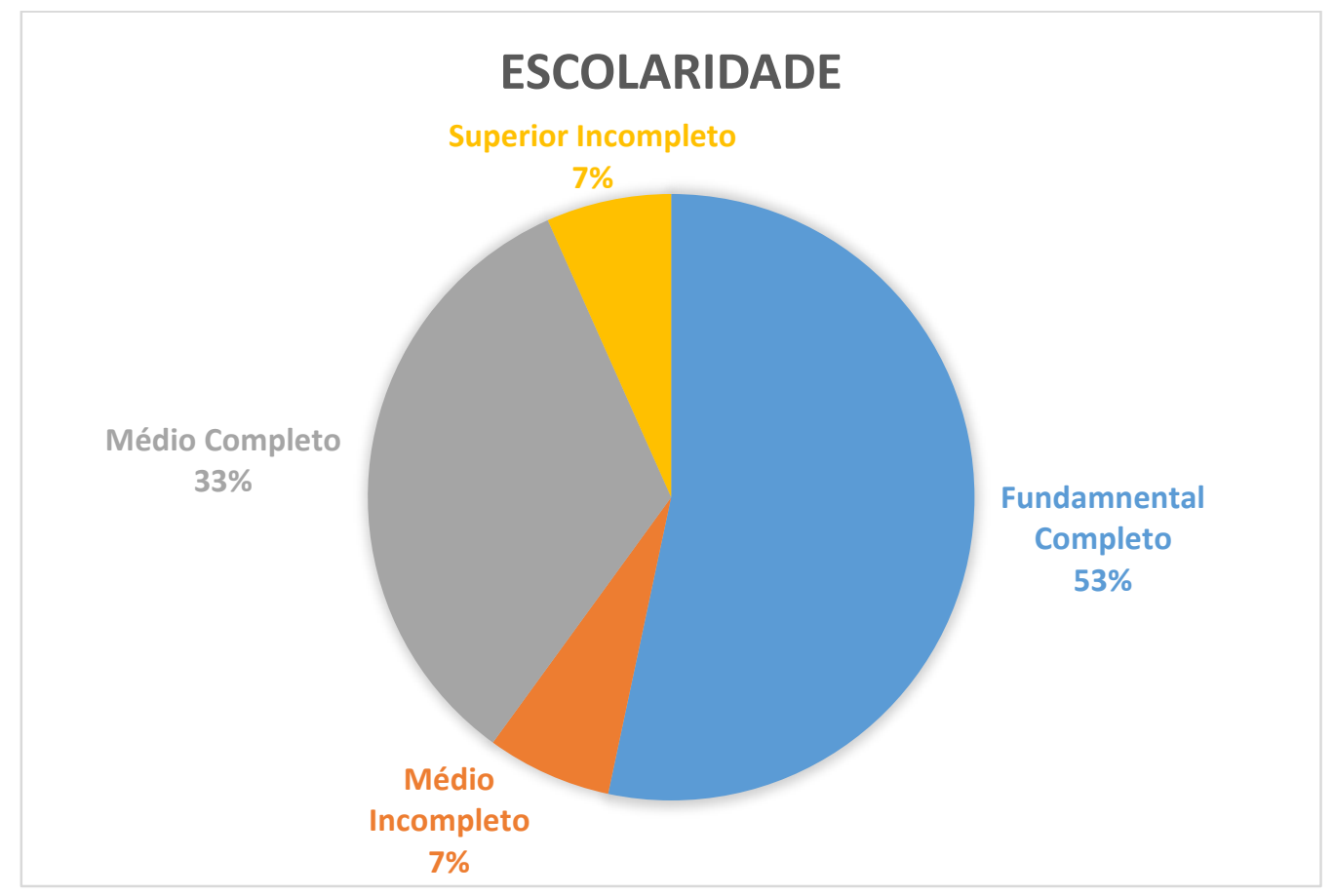

Fonte: Dados da pesquisa, 2015.

Quanto à escolarização, os dados revelam que a metade delas concluiu o ensino fundamental, oito delas possuem o ensino fundamental completo e uma não finalizou o ensino médio, cinco têm o ensino médio completo e uma possui o ensino superior incompleto.

Percebe-se que $\mathrm{o}$ crescimento das políticas públicas sociais $\mathrm{e}$ educacionais tem oportunizado a participação das mulheres em cursos de capacitação, objetivando a elevação da escolaridade, a melhora da autoestima, a socialização, o empoderamento, a produtividade, o emprego e sua inserção no mundo do trabalho. Nesse aspecto o Programa Mulheres Mil é uma referência, pois defende como uma de suas principais prioridades assegurar a educação e à garantia do acesso de mulheres em vulnerabilidade social, que, por inúmeras e variadas razões, tiveram seus estudos interrompidos e ficaram fora do sistema educacional. Ele apresenta e desenvolve atividades para atender ao público feminino carente, incluindo as reeducandas do sistema prisional brasileiro.

O Programa Mulheres Mil tem como uma de suas prioridades promover a elevação da escolaridade. Inicialmente, seria necessário priorizar as participantes com menor grau de escolaridade, devido à relação que existe entre 
baixo nível de escolaridade e baixa renda. Contudo, observou-se que, embora a maioria das alunas tivesse o ensino fundamental completo, havia também, de maneira significativa, as que haviam concluído o Ensino Médio e duas com o ensino superior incompleto.

De acordo com Cravo (2012, p. 242), "[...] quanto aos estudos sobre o ensino básico, os principais motivos da evasão mencionados são problemas socioeconômicos e a inadequação do sistema educacional". Algumas reeducandas da PFDF; entraram na estatística da desistência escolar antes de serem presas. Os motivos de desistência escolar não foram diferentes dos demais e estão intimamente ligados à dinâmica do sistema educacional do nosso país, bem como aos aspectos da vida dos indivíduos, dentre os quais destacamse: a necessidade de melhoria da renda familiar, porque muitas mulheres são as únicas responsáveis pelo seu sustento e de sua família, e também pela a busca do empoderamento e da melhoria da autoestima. Diante disso, muitas mulheres foram obrigadas a abandonar ou a interromper seus estudos. Entretanto, especificamente no caso das reeducandas, esse fato se deu, na vida de algumas delas, em função de suas prisões.

Como citado anteriormente, apenas duas das entrevistadas não possuem filhos. A maioria possui até três filhos. Algumas delas responderam que tiveram seus filhos após ingressarem no PFDF, entretanto, ao cumprir o prazo previsto em lei, essas crianças foram encaminhadas para casa de parentes e/ou instituições responsáveis, fato que causou muita dor a essas mulheres, de acordo com relatos das envolvidas.

A respeito dos tipos de estabelecimentos, o INFOPEN Mulheres (2015), revela que, do total de unidades prisionais do país (1.420), apenas 103 são exclusivamente femininos, enquanto 1.070 são masculinos e 239 são considerados mistos.

"O que se vê, em muitos casos, são estabelecimentos masculinos adaptados precariamente para receber mulheres, não oferecendo condições básicas para elas e para os filhos pequenos, que ficam com as mães até determinada idade", explica a diretora de Políticas Penitenciárias do DEPEN" (Valdirene Daufemback, 2014). 


\section{Gráfico 4- Número de Filhos}

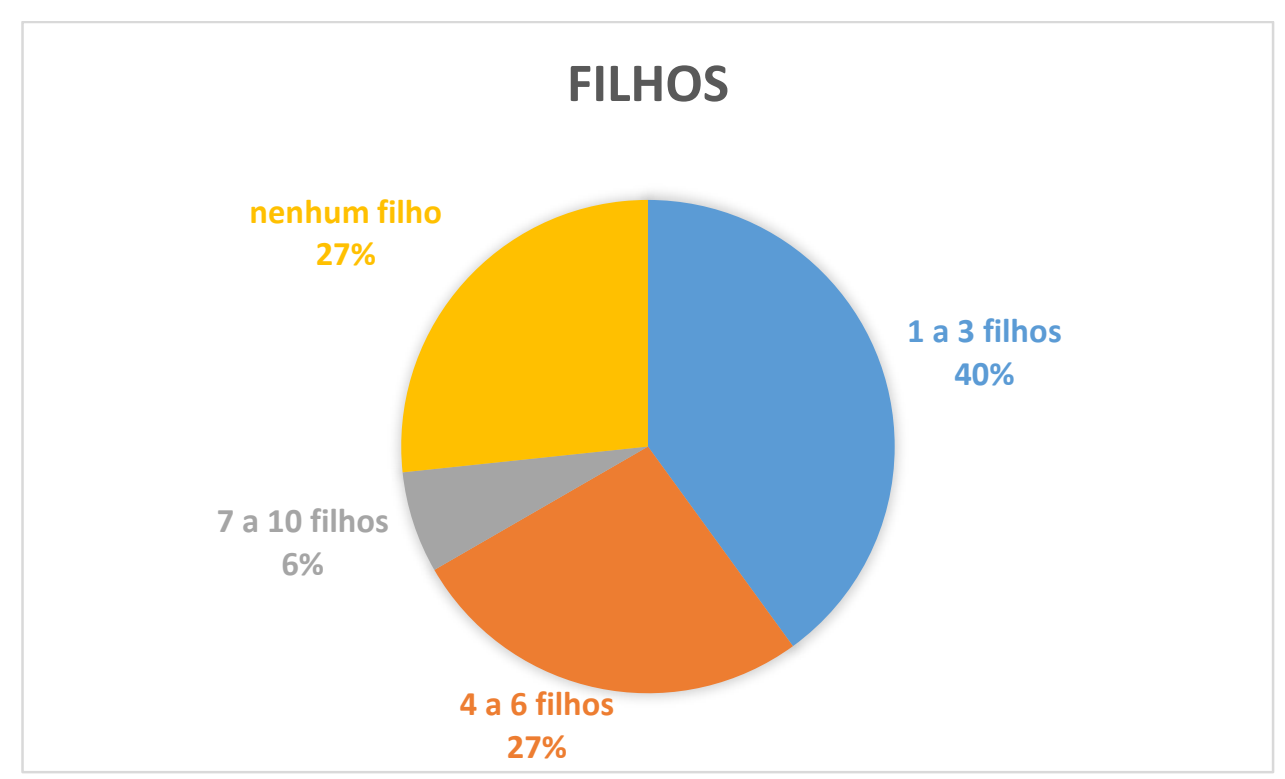

Fonte: Dados da pesquisa, 2015.

Conforme o Gráfico 4, a maioria das reeducandas possui filhos, porém um número considerável delas possui mais de três filhos. Assim percebe-se que ao comparar o número de filhos com o grau de instrução, observa-se que quanto menor a escolaridade maior é o número de filhos.

Existem variadas motivações dentro das penitenciárias, especialmente das femininas, para o exercício de atividades laborais, como a ocupação do tempo ocioso, enfatiza-se o que é apontado como o maior destaque o benefício da Lei que proporciona um dia de remissão de pena para cada três dias trabalhados, nota-se ainda uma maior liberdade de circulação no interior das dependências, àquelas que trabalham nas faxinas ou confecções de lanches ou outras atividades auxiliares para o funcionamento do estabelecimento penal. Vale ressaltar que esse tipo de trabalho desenvolvido pelas reeducandas, apesar de Ihes render um certo "privilégio", ou "vantagens" como refeições melhoradas, comunicação com outras presas, acesso a informações, não lhes traz nenhum tipo de remuneração, portanto, embora que elas exerçam atividades laborais, não percebem renda para que possam auxiliar no sustento próprio ou de seus familiares enquanto permanecem reclusas. 


\section{Gráfico 5 - Em que trabalhava antes de realizar o curso}

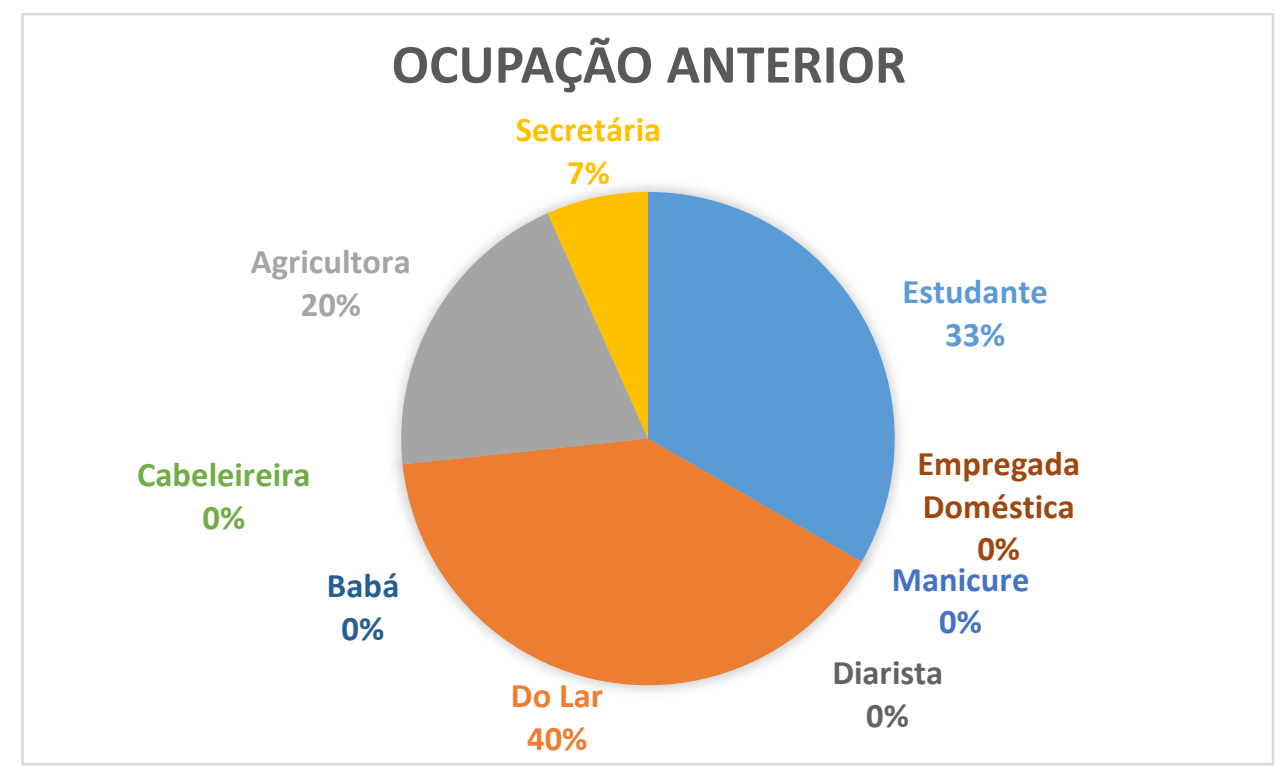

Fonte: Dados da pesquisa, 2015.

Em se tratando de trabalho e de geração de renda, a maioria trabalhava antes de realizar o curso, ou seja, antes de ser reclusa no presídio, e as áreas em que trabalhavam eram variadas, destacando a maior parte na área de trabalhos domésticos, como: dona de casa, empregada doméstica e diarista (Gráfico 5), outras trabalhavam na área de alimentação, como cozinheira, balconista e garçonete e as demais trabalhavam em outras áreas. Segundo Bruschini, Ricoldi e Mercado (2008, p. 25):

Em 2005 , nada menos que $33 \%$ da força de trabalho feminina no Brasil,
ou 12 milhões de trabalhadoras, encontravam-se em nichos precários,
seja como trabalhadoras domésticas, seja realizando atividades não-
remuneradas ou trabalhos na produção para o consumo próprio ou do
grupo familiar.

Conforme alguns estudos, a maioria das mulheres estão inseridas em postos precarizados e de baixa remuneração. Apesar de que, com o passar dos anos, a mulher tenha conquistado alguns espaços de destaque no mundo do trabalho, assumindo cargos nas áreas tecnológicas e científicas, os quais antes só eram ocupados pelos homens, grande parte da população feminina, especialmente àquela de baixa renda e escolaridade, segue desempenhando atividades de baixa remuneração.

Segundo Bruschini, “(...) o emprego doméstico é o nicho ocupacional feminino por excelência, no qual mais de $90 \%$ dos trabalhadores são mulheres" (2008, p.26-27). 
A participação na renda familiar das reeducandas antes de serem presas revela que a maioria delas tinha efetiva participação no sustento de suas famílias, ou seja, contribuíam na renda familiar. Ocorre que depois de haverem participado dos cursos do Programa Mulheres Mil, esperavam desempenhar alguma função laboral, mesmo dentro do presídio, para que além de porem em prática o que aprenderam no curso, gerarem renda para si e para contribuir no sustento de suas famílias. Esse fato não ocorreu, conforme relato abaixo.

Entrevistadora: Você acredita que formação recebida pelo Curso de estética feminina irá contribuir para o seu ingresso no mercado de trabalho? Justifique sua resposta.

Reeducanda A: "Eu amei quando soube que iria participar do curso do programa Mulheres Mil, esse curso me ajudou muito a ver a vida com outros olhos, com mais esperança no meu futuro profissional, mas eu não acredito que eu possa entrar no mercado de trabalho com que aprendi, porém tudo que é ensinado é válido pra passar o tempo aqui dentro e também pra gente ser tratada melhor aqui dentro, mas se fosse ensinado outras coisas como informática, culinária...e se a gente pudesse trabalhar aqui dentro e mandar o dinheiro pra nossa família, seria maravilhoso"

Reeducanda B: "Antes desse curso eu pensava que a minha vida tinha se acabado aqui dentro, eu sentia que não tinha mais solução para mim. Até que veio o Mulheres Mil e os professores me mostraram um novo horizonte, aprendi que sou capaz de realizar outras coisas diferente da criminalidade e que o crime só destrói as nossas vidas e as nossas famílias. Olha o diploma é muito importante, mas eu gostaria de ter aprendido outro curso porque o mercado de trabalho é muito exigente, outra coisa, como é que eu vou trabalhar aqui dentro e ganhar algum dinheiro para ajudar no sustento da minha família lá fora?

O Programa Mulheres Mil tem como objetivo principal qualificar as mulheres em vulnerabilidade social e inseri-las no mundo do trabalho, seja no trabalho formal, empreendedorismo, cooperativismo ou associativismo. Pretende-se contribuir, dessa forma, para a autonomia econômica das mulheres e para a redução da feminização da pobreza. Entretanto, os dados acima revelam que a certificação não contribuiu para a geração e nem para a melhoria 
da renda das reeducandas, certamente, levando-se em conta o ambiente de reclusão onde elas estão inseridas e por não haver convênio, parceria ou acordo com outros órgãos que possibilitassem sua empregabilidade ou geração de renda dentro do presídio. Assim esses fatores contribuíram para que o objetivo principal do programa não tenha sido plenamente alcançado.

Entrevistadora: Onde você pretende desenvolver sua atividade de trabalho adquirida no Programa Mulheres Mil?

Reeducanda A: Eu quero montar meu próprio negócio quando eu sair, mas se isso não acontecer logo, eu vou acabar esquecendo de tudo que eu aprendi aqui, e se demorar muito, o que vai ser da minha família? Seria bom se a gente já começasse a trabalhar aqui dentro para ajudar a família lá fora né!

Reeducanda B: Não sei, não pensei ainda, mas claro que deveria ser aqui dentro, pelo menos começar a trabalhar aqui né. Que adianta aprender e não pôr em prática, com o tempo a gente esquece é tudo.

Das dezesseis reeducandas egressas entrevistadas todas responderam à pergunta de número 7 Onde e como você pretende desenvolver sua atividade de trabalho adquirida no programa Mulheres mil ao sair do presídio. A essa pergunta, elas disseram que estavam felizes com a obtenção do certificado de qualificação profissional do Programa Mulheres Mil, porém não tinham certeza se ao sair seriam capazes de se inserirem no mercado de trabalho, e que seria necessário se criarem postos de trabalho ou algo similar dentro do presidio, para que elas pudessem desenvolver as habilidades adquiridas no programa e assim começassem a gerar renda para si e para ajudar no sustento e de suas famílias. 


\section{Gráfico 6 - Educação}

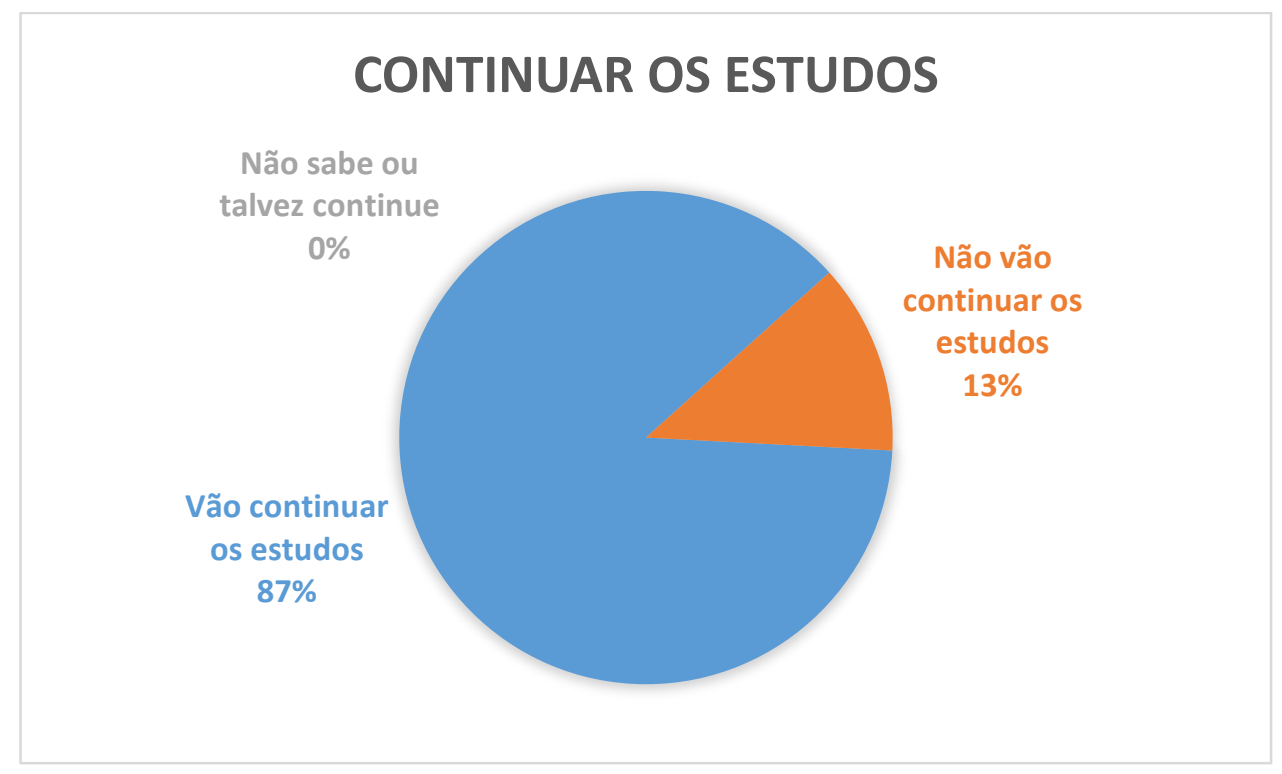

Fonte: Dados da pesquisa, 2015.

Uma das metas que compõem os objetivos do Programa Mulheres Mil, além da qualificação profissional é a elevação da escolaridade. O programa visa proporcionar às alunas não apenas a oportunidade de cursar as disciplinas básicas oferecidas no currículo do curso, mas de retomarem os estudos dentro ou fora dos institutos e continuarem estudando. Das dezesseis reeducandas entrevistadas, quatorze disseram que após o programa Mulheres Mil desejam dar continuidade a seus estudos, enquanto que duas declararam não terem intenção em continuar estudando. Entretanto, no NUEM é ofertada às detentas somente a Educação de Jovens e Adultos -EJA, do primeiro segmento, isso impossibilita às egressas que já concluíram o Ensino Médio a dar sequência aos seus estudos enquanto estiverem reclusas. De acordo com (BRUSCHINI, 2008, p. 20). "A expansão da escolaridade é um dos fatores de maior impacto sobre o ingresso das mulheres no mercado de trabalho".

Das dezesseis mulheres entrevistadas, dez não estudavam ao ingressar no programa Mulheres Mil, destas dez, três voltaram a estudar, das três que retomaram seus estudos, duas foram influenciadas pelo programa. $O$ interessante é que no presídio feminino do Distrito Federal existe uma Escola que oferece o Ensino Fundamental na modalidade EJA- Educação de Jovens e Adultos, e essas três alunas que voltaram a estudar após terem ingressado no Programa Mulheres Mil, já sabiam da existência desta escola, entretanto não 
haviam despertado interesse em retomar seus estudos antes de receberem formação. As outras relataram que embora não tenham tido a oportunidade de retomarem os estudos, o Programa Mulheres Mil despertou nelas esse desejo e voltar a estudar passou a ser um dos objetivos que elas pretendem atingir.

Quanto às contribuições do Programa Mulheres Mil para a melhoria da qualidade de vida, todas as mulheres entrevistadas afirmaram que os componentes ministrados nos dois cursos ofertados pelo Programa Mulheres Mil contribuíram de forma efetiva para a Elevação da autoestima e empoderamento. Os componentes que foram destacados por elas como responsáveis por esta melhoria foram: Noções de Informática e Internet, Educação Financeira, Comunicação Oral, Bio Dança e Estética Feminina. Elas responderam também terem recebido conhecimentos Técnicos Específicos das Áreas dos cursos em que participaram.

\subsection{ANÁLISE DAS PERGUNTAS DISCURSIVAS}

Foram feitas duas perguntas discursivas, as quais foram analisadas utilizando-se a técnica da análise de conteúdo categorial temática, a qual consiste em separar os dados em categorias de acordo com o tema. Nesse sentido as categorias foram sendo constituídas à medida que os elementos iam surgindo na fala das participantes das entrevistas.

\subsubsection{ELEVAÇÃO DA AUTOESTIMA}

A primeira pergunta está relacionada a um dos objetivos do programa Mulheres Mil, trata-se de verificar se os cursos ofertados no interior do presídio contribuíram efetivamente para a elevação da autoestima das reeducandas egressas.

A autoestima é a valorização positiva, que o indivíduo tem de si mesmo. Trata-se da opinião emocional favorável que as pessoas têm delas próprias e que excede a própria racionalização e a lógica. Por outras palavras, a autoestima é um sentimento valorativo do conjunto das nossas características corporais físicas, mentais e espirituais que formam a personalidade. 
A autoestima é frequentemente definida como a componente avaliativo e valorativo da pessoa acerca de si mesmo. Esse componente, por sua vez, está diretamente relacionado com as habilidades reais da pessoa (Arsenian, 1942, apud. Korman,1967).

A elevação da autoestima foi um dos fatores mais apontados como positivos pelas reeducandas entrevistadas. Elas afirmaram que o programa contribuiu efetivamente para que elas se sentissem confiantes, na vida, em si mesmas, felizes e com grandes expectativas de planos para o futuro, especialmente em dar continuidade aos estudos e em realizar seus sonhos.

Reeducanda1: Minha autoestima melhorou demais depois das aulas do Programa Mulheres Mil, sinto desejo de me arrumar, converso com as colegas, com os professores. Me sinto viva. Já tenho até planos para quando eu sair.

Reeducanda 2: Não é porque eu to aqui dentro da Colméia, que eu não tenha o direito de sonhar, sei que eu tenho, mas depois das aulas é que eu pude entender isso, que eu posso ter qualidade de vida, mesmo ainda estando aqui, tenho direito de fazer planos para o futuro, isso ninguém pode me tirar, mas eu não sabia.

Reeducanda 3: O Curso de Recepcionista me proporcionou uma melhora muito grande na autoestima, me pôs para cima, levantou meu astral em todos os sentidos. Hoje sou outra pessoa, ainda que eu não possa trabalhar porque estou pagando aqui o que eu fiz lá fora, ainda assim me sinto capaz de realizar meus sonhos quando sair.

Reeducanda 4: Os professores do Mulheres Mil nos trataram como seres humanos, nos fizerem ver como temos valor, apesar do que fizemos de errado para a sociedade. $E$ isso não tem preço.

Reeducanda 5: Eu só tenho que agradecer aos professores porque agora eu sou mais feliz, gosto de me olhar no espelho, gosto de cantar, fico sonhando com o mundo lá fora, um mundo melhor para mim, para as pessoas que eu prejudiquei e principalmente para minha família. 


\subsubsection{QUALIFICAÇÃO}

A segunda pergunta aberta trata-se da qualificação. Sabe-se que o objetivo principal do Programa Mulheres Mil é qualificar profissionalmente mulheres em condição de vulnerabilidade social, com vistas a seu ingresso no mercado de trabalho, seja no mercado formal ou informal. Desta forma esperase que as desigualdades econômicas e sociais das mulheres sejam diminuídas.

Esse objetivo foi apresentado às reeducandas do presídio feminino do DF, tanto para às que tinham formação e já desenvolviam alguma atividade laboral como também àquelas que não tinham e estavam ociosas.

A qualificação profissional e o aperfeiçoamento nos conhecimentos das áreas de Recepcionista e Estética foram apontados como uma das maiores expectativas das reeducandas ao se inscreverem nos cursos.

Reeducanda 1: Já tinha uma qualificação, mas ao chegar aqui a gente é forçada a esquecer o mundo lá de fora, e eu queria começar de novo. Deu certo!

Reeducanda 2: A minha meta era me qualificar profissionalmente, agora quero trabalhar.

Reeducanda 3: Capacitação profissionalizante

Reeducanda 4: Ser qualificada e ter um diploma era tudo que eu queria, quando falaram que a gente ia estudar e se qualificar, fiquei muito feliz.

Reeducanda 5: Minha expectativa era aprender as coisas da área de recepcionista.

Percebe-se que o anseio por adquirir uma qualificação profissional, está ligado ao desejo de entrar no mercado de trabalho, de produzir, de gerar renda, e essa expectativa não é diferente nas reeducandas, não difere de outras mulheres que não se encontram em situação de privação de liberdade.

Entende-se que as pessoas qualificadas têm mais oportunidades de ingressar e de se manter no mundo do trabalho em detrimento daquelas que não possuem qualificação. Diante disso o Governo federal tem investido muito nos 
últimos anos sem políticas de capacitação profissional. Devido ao mercado exigir a cada dia mais qualificação e fomentar uma grande competitividade, os que possuem mais competência, que investiram em seus estuados, qualificação, são os que conseguem e se mantêm nos melhores postos de trabalho.

Conforme a Teoria do Capital Humano, já citado anteriormente, ter uma maior escolarização, uma maior qualificação é fator determinante para a melhoria da qualidade de vida dos indivíduos, porque o aumento da renda está diretamente ligado à sua melhor qualificação para o mercado de trabalho. Assim os indivíduos são os próprios responsáveis pelos salários que eles recebem. (Cunha, 2007, p.28).

Em contrapartida, essa mesma teoria ignora em suas análises que a população que se encontra à margem, sem condições financeiras para custear essa qualificação e nem tem tempo para fazê-la, tem que trabalhar em subempregos, muitas vezes com precárias remunerações. Com isso são perpetuadas as desigualdades que são comuns no sistema capitalista.

Por ser previsto nas diretrizes do programa o direcionamento ao mundo do trabalho e o incentivo ao empreendedorismo, ao cooperativismo ou associativismo, as dezesseis reeducandas que responderam ao questionário, vislumbraram ao se inscreverem no programa a chance de, além de se qualificarem, encontrarem uma oportunidade de gerar renda, inclusive e especialmente, mesmo ainda em cumprimento de suas penas.

Reeducanda 1: Minha intenção era assim que acabasse o curso eu já começasse a trabalhar e ganhar meu dinheiro.

Reeducanda 2: Eu pensei que quando acabasse o curso nós já fossemos encaminhadas para algum serviço. Mas aqui dentro fica difícil.

Reeducanda 3: Meus objetivos eram ser valorizada aqui dentro e lá fora.

Reeducanda 4: Entrei nesse curso para aprender uma profissão, cansei do crime.

Reeducanda 5: Melhorar o currículo, aprender uma profissão ser mais valorizada e ganhar dinheiro com isso. 
Conforme as respostas acima, percebe-se claramente o afã de se obter uma qualificação e que o aprendizado que o curso proporcionou lhes dê a oportunidade de trabalhar e gerar renda, tanto quando saírem ou principalmente enquanto ainda estiverem cumprindo pena no sistema fechado.

\subsubsection{ANÁLISE DO GRUPO FOCAL}

Para compor a metodologia deste estudo, foi realizado um grupo focal com as reeducandas. Para esta etapa, selecionou-se oito participantes, metade daquelas que responderam ao questionário.

Por se tratar de um instrumento que já vem sendo utilizado há muito tempo e cada vez mais no âmbito das abordagens qualitativas, é que se elegeu o grupo focal para analisar as reações das reeducandas participante frente as questões debatidas. "Um conjunto de pessoas selecionadas e reunidas por pesquisadores para discutir e comentar um tema, que é objeto de pesquisa, a partir de sua experiência pessoal". Utilizando as palavras ditas por Powel e Single (1996, p.449 apud GATTI, 2012, p.07).

O objetivo da utilização do grupo focal nesta pesquisa deu-se em face da necessidade de apreender a importância e o significado do Programa Mulheres Mil, conforme o ponto de vista das reeducandas egressas dos cursos de Estética Feminina e Recepcionista, saber quais as contribuições e as consequências proporcionadas pelo programa em suas vidas, quanto à ressocialização, a expectativas de inserção no mundo do trabalho e à geração de renda, mesmo ainda estando reclusas no cumprimento de suas penas.

As oito reeducandas egressas que haviam sido selecionadas para participar do grupo focal foram indicadas pela Diretora do NUEN, em virtude de elas não terem se envolvido em nenhuma ocorrência nos últimos meses, conforme explicou a diretora, esse aspecto é muito relevante, dado ao fato do tempo em que se passa dentro de uma sala só com as entrevistadas, pois a carcereira não participou das entrevistas, ficou do lado de fora da sala. A reunião ocorreu no interior do próprio núcleo de ensino no dia 15 de setembro de 2015 com a duração de uma hora e meia, a própria pesquisadora foi a condutora das discussões. 
Ao iniciar a reunião, a moderadora agradeceu às participantes, explicou o motivo pelo qual elas estavam ali, enfatizou que todos os dados obtidos na entrevista eram sigilosos e confidenciais e que somente seriam utilizados para fins de pesquisa conforme o consentimento prévio que elas já haviam dado. Foi esclarecido que cada participante era livre para se expressar de acordo com o entendimento dos questionamentos feitos e que elas não seriam filmadas, apenas suas vozes gravadas, por determinação da VEP.

Com vistas a atender aos objetivos deste estudo foram elaboradas quatro questões norteadoras para conduzir as discussões. A primeira pergunta objetivava apreender o significado que o Programa Mulheres Mil exerceu na vida das reeducandas participantes. A segunda fazia um questionamento a respeito da possibilidade da reinserção no mundo do trabalho com vistas a geração de renda por meio das qualificações recebidas nos cursos ofertados pelo Programa.

A terceira pergunta estava relacionada às contribuições do programa acerca da mudança de seus itinerários formativos, se elas haviam mudado de opinião, de pensamento, com relação aos motivos que as levaram ao presídio. E se o Programa havia despertado o desejo de retomar os estudos. A última pergunta pretendia saber se as etapas do Programa, previstas, haviam sido cumpridas.

As discussões ocorreram com muita tranquilidade, todas as reeducandas se expressaram e deram suas opiniões de forma muito favorável ao programa, elogiaram muito a paciência, o carinho e a forma afetuosa com a qual foram tratadas pelos professores pelo coordenador. Porém quando questionadas a respeito da etapa do programa que prevê o encaminhamento ao mercado de trabalho elas não souberam responder ou ignoraram a pergunta.

O produto obtido com essas discussões - as gravações e o relatório, foram ouvidos, lido e transcrito para poder ser analisado. A observação foi realizada baseada na técnica de análise de conteúdo eleita para essa pesquisa, descrita anteriormente. Quanto ao procedimento, utilizou-se o mesmo das questões discursivas do questionário semiestruturado.

Com base nas falas das reeducandas as categorias foram preestabelecidas e as subcategorias foram criadas, conforme os temas surgiam 
e também de acordo com o número das ocorrências. As categorias são: As Consequências do Programa para a Ressocialização e a Qualificação e Geração de Renda.

\subsection{CONSEQUÊNCIAS DO PROGRAMA MULHERES MIL PARA A RESSOCIALIZAÇÃO}

Ao solicitar que as reeducandas expressassem quais as consequências do programa Mulheres Mil em suas vidas, buscou-se apreender a visão das mulheres para as quais essa política pública foi criada. Esperava-se que as mulheres ao falarem do que o programa lhes trouxe de forma direta ou indireta se comprovasse os benefícios que o Programa proporcionou a outras reeducandas beneficiadas. Com base nas falas das reeducandas outras subcategorias foram surgindo; Elevação da autoestima e Interação social.

\subsubsection{ELEVAÇÃO DA AUTOESTIMA}

Com relação à importância do Programa para a elevação da autoestima, as respostas foram unânimes, ou seja, todas elas relataram ser essas uma das principais contribuições promovidas pelo programa em suas vidas.

Reeducanda 1: Mulher, pense numa pessoa que não tinha mais ânimo para nada, parecia que o mundo tinha acabado para mim, eu nem queria mais sair da cela, nem conversar com as colegas, foi quando comecei a ter as aulas e sentir o carinho e principalmente o respeito que o professor Sérgio tinha comigo. Depois disso comecei a mudar, hoje já até falo demais né professora?

Reeducanda 2: Eu fui muito humilhada em toda minha vida, sofri estupro, fui traída, abandonada, perdi filho, mãe, perdi a dignidade. Autoestima, o que era isso? Hoje depois do Mulheres Mil e dos outros cursos que deixaram eu fazer aqui, eu acredito em mim, acredito que tenho recuperação e tudo que me fizeram passar eu posso usar para ajudar a outras mulheres a não passarem, e se passarem se 
levantarem assim como eu.

Reeducanda 3: Aprendi que o crime não compensa, aprendi a valorizar o próximo e a mim mesma.

Reeducanda 4: Eu vivia em depressão, mas presa e pobre não pode ter essa doença não. Foi aí que me mandaram fazer o curso, eu vim sem querer, mas depois que vi o respeito e o carinho que os professores do curso tratam a gente aqui, meu Deus foi um santo remédio, nunca mais fiquei deprimida na minha vida. Só queria que tivessem outros cursos desses aqui dentro.

Reeducanda 5: Moço, ei olha aqui, eu agora sei o que é autoestima e baixo autoestima. Eu tenho autoestima, eu me amo, assim eu vou amar e respeitar o meu semelhante.

Reeducanda 6: Falar de autoestima para uma pessoa livre é uma coisa, agora para quem estar nesse lugar, pagando pelo crime que cometeu, aí meu amigo a coisa é séria, tem que ter muita paciência e amor pelo outro. Foi exatamente isso que eu vi aqui dentro com o pessoal do Mulheres Mil.

Reeducanda 7: Eu gostava muito quando o professor falava que a gente tinha capacidade de mudar, que a vida não tinha acabado só porque a gente estava aqui, e que cada uma de nós tinha o seu valor.

Reeducanda 8: Uma coisa que eu nunca vou me esquecer é que eles botaram a gente para cima, ah! Isso eles fizeram muito bem. Agora tenho até vontade de me arrumar, pentear os cabelos, conversar com minhas colegas, quase nem choro mais.

\subsubsection{INTERAÇÃO SOCIAL}

O aspecto mais importante da interação social é que ela modifica o comportamento dos indivíduos envolvidos, como resultado do contato e da comunicação que se estabelece entre eles. Desse modo, fica claro que o simples contato físico não é suficiente para que haja uma interação social. Os contatos sociais e a interação são, portanto, condições indispensáveis à associação humana.

As pessoas se socializam por meios dos contatos e da interação social; e a interação social pode ocorrer entre uma pessoa e outra, entre uma pessoa e 
um grupo e outro. Nas palavras de Paulo Freire, (2007), somos seres de relação, incompletos, inacabados e inconclusos, que não existimos sem o outro, daí essa necessidade de conviver, de se relacionar, de compartilhar e afirmar nossa presença no mundo. Foi por tudo isso que muitas das reeducandas entrevistadas relataram, que assim como a elevação da autoestima, a interação social também foi uma das expectativas que elas almejaram ao participar do programa.

Para algumas mulheres, só o simples fato de saírem de suas celas, verem, ouvirem, dialogarem com pessoas diferentes daquelas com as quais elas estão habituadas a conviver desde que foram presas já faz uma grande diferença em suas vidas. Outro fato marcante em relação à interação social deu-se pelo fato de elas serem chamadas pelos professores pelos seus próprios nomes, pois no presídio todas elas são chamadas de "internas"

Reeducanda 1: Eu adorava quando tinha aula, eita era uma festa! Depois que passava do corredor agente podia conversar, dar gargalhada, fazer as brincadeiras, agente estudava e se divertia também.

Reeducanda 2: Bom mesmo era quando o professor fazia as dinâmicas, menina agente ria, esquecia os problemas lá de fora e os de dentro. As vezes a gente pensa que só nós é que temos problemas e que os nossos são maiores que os dos outros, na dinâmica que a gente fez uma vez eu aprendi que não é bem assim.

Reeducanda 3: Gostei muito das aulas, das conversas com as colegas, até o pessoal daqui olha agente diferente porque ver que a gente está se esforçando, está querendo mudar. É muito bom conhecer outras pessoas, gente que vive quase no mesmo teto que você, mas que nunca se falaram, aí vem um curso e aproxima agente. Isso é maravilhoso. 


\subsubsection{QUALIFICAÇÃO E GERAÇÃO DE RENDA}

Um dos objetivos dessa pesquisa é saber se o Programa Mulheres Mil contribuiu para a geração ou para a melhoria da renda das reeducandas egressas dos cursos de Estética Feminina e Recepcionista. Com esse propósito, no decorrer do grupo focal essa temática foi muito bem explorada, especialmente por haver sido constatado que, por meio do questionário que foi aplicado antes, essa meta não tinha sido alcançada, dado a situação legal em que as reeducandas se encontram.

De todo o processo que envolveu a pesquisa de campo, este foi o mais tenso e polêmico, pois as reeducandas não tinham conhecimento desta meta do programa e por desconhecerem, pediram que fosse explicado a elas, o que gerou um certo desconforto para a pesquisadora, pois elas se mostraram decepcionadas ao saber que o programa deveria encaminhá-las para o mercado de trabalho, ou incentivá-las a geração ou melhoria da renda. Fato que não aconteceu por diversos fatores que posteriormente serão explicados.

Reeducanda 1: Eu até gostei do curso, achei interessante, aprendi algumas coisas, mas como é que vou botar em prática o que aprendi se aqui dentro não temos chance?

Reeducanda 2: Meu propósito em fazer o curso foi me qualificar profissionalmente, mas para isso preciso colocar em prática, tenho que trabalhar, ajudar minha família que ficou lá fora. Como é possível que isso aconteça, se eu ainda nem fui julgada?

Reeducanda 3: Aqui a gente trabalha sabia? Mas só que não ganhamos nada, é só para a remissão de pena. Eu não acho justo, eu me qualifiquei, eu tenho família, eu não ganho o auxílio porque eu não era fichada quando eu caí.

Reeducanda 4: Eu não aprendi muita coisa no curso da parte de trabalho, porque foi muito rápido, mas o pouco que aprendi eu gostaria de poder botar em prática. Disseram que quando a gente sair agente pode procurar o IFB que vão nos ajudar a arrumar serviço, mas quando será que eu vou sair daqui meu Deus?

Reeducanda 5: Eu só sei que quando eu sair eu quero botar meu 
próprio negócio, pode ser na área de comida, pode ser no salão, ou venda de roupa, porque se a gente for querer trabalha fichado eles não vão querer aceitar por causa do nosso passado.

Reeducanda 6: Se tivesse como agente já ter um trabalho aqui dentro mesmo seria melhor. Ai quando a gente saísse, já ia continuando no mesmo ramo. Fala isso para o pessoal do IFB professora.

Reeducanda 7: Bom, para mim, na teoria foi uma coisa, agora na prática foi muito fraco, os professores foram ótimos, mas eles foram até onde puderam, na verdade nem sei se poderei conseguir algum trabalho com os conhecimentos que adquiri nesse curso.

Reeducanda 8: Eu gostei das aulas de informática, eu aprendi as noções de como ser uma recepcionista, ética, língua portuguesa etc.

Eu poderia muito bem trabalhar aqui no presídio, claro que se eu me oferecer eles aceitam e até me dão a remissão da pena, mas e ai, eu não vou ganhar nada pelo desenvolvimento do meu trabalho? Eu sou uma reeducanda, estou pagando pelos meus atos, mas eu conheço os meus direitos.

O documento de referência do Programa Mulheres Mil, o seu guia metodológico, aponta que, no momento de implementação do programa deverá ser garantido mecanismos que possibilite a permanência e êxito das alunas. Isto terá que ser realizado por meio de articulação com o setor produtivo, para que seja feita a inserção das egressas no mundo do trabalho e com vistas à continuidade da formação profissional.

Na realização do grupo focal foi perguntado se no decorrer do curso foi construído o Portfólio delas. O portfólio é um tipo de documento que contém as informações sobre os conhecimentos, competências e habilidades, inclusive seus documentos formais e informais, como fotos, anúncios de alguns trabalhos e conhecimentos prévios destas alunas. De acordo com o guia metodológico, ele é um instrumento que poderá ser apresentado ao empregador, servindo como currículo, especialmente para as reeducandas que não possuem documentos comprobatórios de atividades laborais anteriores.

As alunas informaram não ter conhecimento desse documento e que o mesmo não foi construído com elas. Elas disseram que, desde o início dos dois cursos, foi informado a elas que não haveria o encaminhamento ao emprego, 
isso se deu devido a situação de privação de liberdade em que elas se encontravam, contudo elas intuíram que poderiam desenvolver as habilidades adquiridas nos cursos ofertados depois de cumprirem suas penas.

Elas disseram também que não foram consultadas a respeito de quais cursos gostariam de realizar por meio do programa, afirmaram não se sentirem qualificadas e nem preparadas para voltarem ao mercado de trabalho. Muitas delas almejam trabalhar e receber o pagamento pelas atividades laborais, enquanto estão no presídio, outras disseram que temem esquecer o pouco que aprenderam ali dentro, por isso gostariam de pôr em prática e ganhar com isso.

A metodologia utilizada no programa Mulheres Mil é formada por dois módulos: Acesso, Permanência e êxito. O acesso é feito por meio da aproximação com a comunidade, a fim de incluí-la nas instituições educacionais com vistas a proporcionar a sua participação efetiva no processo de formação, elevação de escolaridade e de inserção no mundo do trabalho. (BRASIL, 2014, p.4).

Já o módulo de permanência e êxito "consiste em um conjunto de ações multidisciplinares direcionadas ao atendimento das educandas, neste caso específico, as reeducandas, (grifo meu).

Dentre os objetivos desse módulo, estão: "viabilizar e firmar parcerias com instituições públicas e privadas para possibilitar a inserção das egressas no mundo do trabalho; acompanhar e monitorar as "(re)" educandas nos estágios e no desempenho profissional." (BRASIL, 2011, p. 26 e 27).

Por meio das respostas, das falas, das expressões, reações e opiniões das reeducandas participantes dos dois cursos ofertados no presídio feminino, pode-se deduzir que o Programa não conseguiu cumprir, na totalidade com o que propunha seu documento base, porém, entende-se que para este público específico e diferenciado de mulheres, deveria ter sido dado, por parte do IFB, mais apoio à equipe gestora, mais diálogo e parceria com instituições ligadas ao mundo do trabalho, como está previsto no guia metodológico, sobretudo, mais experiência para poder atender e entender esse público, historicamente excluído dos programas de assistência, as mulheres privadas de liberdade. 


\section{CAPÍTULO 6}

\section{MODELO SUSTENTÁVEL DO PROGRAMA MULHERES MIL PARA O SISTEMA PRISIONAL DO DISTRITO FEDERAL}

Compreender o motivo pelo qual, na dinâmica do mundo contemporâneo, ainda existam instituições, públicas, como, por exemplo, os presídios, que permanecem utilizando costumes, punições desumanas, e práticas obsoletas, que perduram há séculos, é um paradoxo, pois a evolução do mundo nos remete à necessidade de inovação em todos os segmentos da sociedade, inclusive nos presídios, onde a educação torna-se divergente. Nesse sentido (FOUCAULT, 1996, p. 32) traz a seguinte contribuição a esse respeito:

[...] mas eram revoltas contra toda uma miséria física que dura há mais de um século: contra o frio, contra a sufocação e o excesso de população, contra as paredes velhas, contra a fome, contra os golpes... Como se trata disso nos inúmeros discursos que a prisão tem produzido desde o começo do século XIX.

Entende-se que a inovação deverá ocorrer nos mais variados contextos e com amplitudes bem diferentes, que vão desde uma aula, um modelo de gestão educacional diferenciado e até a uma política pública, como por exemplo, uma política de reinserção social, direcionada exclusivamente ao sistema prisional feminino, entendendo esta política pública como um conjunto de intervenções e ações do Estado que são orientadas para a geração de impactos nas relações sociais em qualquer contexto que necessitem de intervenções seja no âmbito educacional, social ou político.

A legislação penal vigente, Lei de Execuções Penais- LEP, (1984), prevê que a assistência educacional das reeducandas, compreenderá a instrução escolar e a formação profissional. Desse modo oferece como obrigatório o Ensino Fundamental, integrando-o no sistema escolar da unidade federativa, enquanto o ensino profissional deverá ser ministrado em nível de iniciação ou de aperfeiçoamento técnico.

A participação das internas presas somente em atividades educacionais, esportivas e culturais, não lhes proporciona o direito à remissão da pena, a lei determina que só por meio da ocupação pelo trabalho é que o preso (a) terá 
direito a esse benefício.

Em função da desfederalização do Direito Penal, fica sob a responsabilidade dos estados a implementação de políticas no sistema prisional, variando conforme a região e em face à da diversidade cultural, econômica e social de cada estado da Federação, posto que a realidade penitenciária brasileira é extremamente heterogênea.

Em alguns estados a temática da educação, por exemplo, é interpretada na Lei de Execuções Penais distintamente. Enquanto uns como o Rio Grande do Sul, Rio de Janeiro e Roraima, vêm investindo na implementação de ações políticas de incentivo à educação como prática na execução penal, outros pouco ou quase nada fazem nessa direção.

No estado de Roraima, por exemplo, a prática da remissão de pena pelo ensino, embora não prevista na Lei de execuções Penais, já é adotada há muito tempo, com sucesso, à base de um dia de pena para doze horas de estudo. $O$ Rio de Janeiro, conforme (ONOFRE, 2013, p.37) [...] seguindo a experiência do Rio Grande do Sul, em 2000, instituiu um acordo entre os órgãos responsáveis pela execução penal, permitindo a remissão por meio da educação.

\subsection{A EXPERIÊNCIA DE RORAIMA}

O estado de Roraima desenvolve desde 2009, no Complexo Penitenciário do Monte Cristo, nos presídios masculino e feminino, diversos projetos na área educacional, por meio de um convênio firmado entre as Secretarias de Justiça e Cidadania (SEJUSC) e de Educação, Cultura e Desportos,(SECD), para instalar e manter escolas de Ensino Fundamental, Médio e EJA, nos três segmentos na referida unidade prisional, e ainda, no complexo feminino, por meio de convênio firmado há sete anos, entre o antigo Centro Federal de Educação Tecnológica de Roraima - CEFETRR, e que se estende até os dias atuais, com então Instituto de Educação, Ciência e Tecnologia de Roraima -IFRR, por meio do Programa Mulheres Mil, que já qualificou profissionalmente mais de cem reeducandas com o curso de Qualificação Profissional em Culinária Regional, ao tempo que, em razão da parceria com a SECD, faz a elevação da escolaridade das reeducandas. 
Além do convênio feito com a Secretaria de Educação, firmaram-se outros acordos com ONGs, instituições religiosas, Sistema "S" - SESI, SENAI, SENAC SEST SENAT e Universidades Públicas do Estado, um grande exemplo de parceria é o Projeto denominado "João de Barro", que foi instituído há dez anos entre Secretaria de Justiça de Roraima- SEJUSC e Universidade Federal de Roraima-(UFRR), cujo objetivo é a promover a ressocialização de reeducandos do regime fechado, mas sem oferecer-Ihes a formação educacional, somente por meio do trabalho, realizado por intermédio de parcerias com a iniciativa privada.

A fim de manter o compromisso com a educação do sistema prisional, em fevereiro de 2014, o estado de Roraima criou, no interior do Complexo Penitenciário uma escola genuinamente de educação profissional, conforme o DECRETO N 16.657-E DE 18 DE FEVEREIRO DE 2014: "Dispõe sobre a criação da Escola Estadual do Sistema Prisional Prof. ${ }^{a}$ Crisotelma Francisca de Brito Gomes, que funcionará na Penitenciária Agrícola do Monte Cristo na comunidade de Monte Cristo, no município de Boa Vista e dá outras providências". O GOVERNADOR DO ESTADO DE RORAIMA, no uso das suas atribuições que Ihe confere o art. 62, inciso III, da Constituição Estadual, resolve:

Art. $1^{\circ}$ Fica criada a Escola Estadual do Sistema Prisional Professora Crisotelma Francisca de Brito Gomes, localizada na comunidade de Monte Cristo, município de Boa Vista, no Estado de Roraima ${ }^{1}$.

Art. $2^{\circ} \mathrm{A}$ Escola Estadual do Sistema Prisional Professora Crisotelma Francisca de Brito Gomes, ministrará a Educação Básica na modalidade de Educação de Jovens e Adultos/EJA - $1^{\circ} 2^{\circ}$ e $3^{\circ}$ segmentos.

Art. $3^{\circ} \mathrm{A}$ Escola Estadual do Sistema Prisional Professora Crisotelma Francisca de Brito Gomes utilizará as dependências da Penitenciária Agrícola do Monte Cristo.

Art. $4^{\circ}$ As despesas com criação da Escola Estadual do Sistema Prisional Professora Crisotelma Francisca de Brito Gomes, correrão à conta e dotação orçamentária própria da Secretaria de Estado de Educação e Desporto.

Art. $5^{\circ}$ Caberá aos órgãos próprios do Sistema Estadual de Ensino fornecer, apoiar, orientar, coordenar e prover a Unidade Escolar com recursos humanos e materiais para seu pleno funcionamento.

Com o intuito de evitar constrangimentos aos concluintes de cursos realizados

\footnotetext{
${ }^{1}$ A escola inaugurada no interior da penitenciária agrícola do Monte Cristo- PA, recebeu o nome da irmã da pesquisadora professora Crisotelma Francisca de Brito Gomes, que faleceu no período em que esta Coordenava o Programa Mulheres Mil no IFRR.
} 
na Escola Estadual do Sistema Prisional, considerando que os Certificados de conclusão expedidos constariam obrigatoriamente o nome da escola, com a expressão "Sistema Prisional" a denominação da Escola foi alterada, de acordo com o Decreto Estadual № 17.675-E de 2 de outubro:

"Art. $1^{\circ}$ Fica alterada a denominação da Escola Estadual do Sistema Prisional Professora Crisotelma Francisca de Brito Gomes, localizada na comunidade de Monte Cristo, município de Boa Vista, no Estado de Roraima, que passa a denominar-se Escola Estadual Professora Crisotelma Francisca de Brito Gomes".

A maioria das atividades desenvolvidas no sistema penitenciário do país tem a simples finalidade de tirar os internos do ócio, mesmo que nada venha a Ihes acrescentar. Várias ações políticas vêm colaborando para ampliar as atividades educacionais ora em desenvolvimento, entretanto não é estranho admitir que o sistema penitenciário brasileiro, valorize o trabalho em detrimento do estudo. Neste aspecto o estudo é visto apenas como mero complemento do trabalho.

Apesar desta experiência exitosa do estado de Roraima já ser executada há alguns anos, pouco foi documentado, registrado e discutido sobre o assunto no estado e obviamente no restante do país.

Diante desse cenário, é necessário verificar que de acordo com o Art. $6^{\circ}$ da Constituição Federal, (1988), são direitos sociais: a educação, a saúde, a alimentação, o trabalho, a moradia, o lazer, a segurança, a previdência social, a proteção à maternidade e à infância, a assistência aos desamparados, na forma desta Constituição (Redação dada pela Emenda Constitucional nº 64, de 2010), todavia, pouco resulta os direitos estarem previstos na Constituição se não houver políticas públicas concretas que efetivem esses direitos.

Reduzidas a quase nada são as discussões que vêm sendo implementadas nessa direção. O reconhecimento da importância no contexto político, da prática carcerária também ainda é muito inexpressivo. Isso demonstra que as unidades penais ainda não possuem ações regulares de ensino, visto que o grande interesse dos internos nas penitenciárias são as atividades laborais, pois estas Ihes proporcionam ganhos financeiros, além de abater parte da pena. Contudo ainda são raros ou quase não existem registros na literatura; que comprovem a prática laboral remunerada exercida por mulheres privadas de liberdade. 
Na Penitenciária Agrícola do Monte Cristo, (PA), Complexo Penitenciário do Estado de Roraima foram ofertados entre os anos de 2009 a 2012, quatro cursos a quatro turmas de reeducandas, desde o projeto piloto até a adesão do Programa Mulheres Mil ao PRONATEC, nesse período foram qualificadas mais de cem mulheres detentas, no Curso de Culinária Regional.

$\mathrm{Na}$ matriz Curricular dos cursos ofertados às reeducandas da penitenciária Agrícola do Monte Cristo, (PA) constavam os componentes de Empreendedorismo e Associativismo, e com base na necessidade de ampliar o conhecimento repassado às mulheres e ainda pela carência de professores qualificados nas áreas relacionadas nesses componentes que foram ministrados, o IFRR firmou parcerias com alguns órgãos, entre eles o Sistema "S". Essa parceria foi significativa para o Programa, mas especialmente para a Secretaria de Justiça e Cidadania, órgão que representa em Roraima, o sistema prisional.

Os parceiros SESI, SENAC/RR, SENAR/RR e OCB-SESCOOP, além de ministrarem as aulas práticas, desenvolveram as disciplinas teóricas das respectivas áreas para o curso de culinária regional. No interior do presídio foi montada uma cozinha industrial com recursos oriundos dos Colleges canadenses e sob a supervisão da gestão do então projeto Mulheres Mil. Essa cozinha serviu de laboratório para as aulas práticas. Com o término do curso a referida cozinha foi doada ao presídio, por meio de um acordo celebrado entre o IFRR e SEJUSC.

Os pratos confeccionados nas aulas práticas eram degustados pelos funcionários do presídio, que elogiavam o sabor, a qualidade e o cuidado que elas dispensavam à elaboração. Ao término dos cursos, as reeducandas ficavam ociosas e sem ter como comercializar os pratos. Diante da situação pensou-se em criar uma cooperativa cujo intuito seria escoar o produto confeccionado por elas, de forma organizada e com vistas à geração de renda. Desta forma foi criada uma cooperativa de produção de alimentos, do prato básico, trivial ao mais elaborado. Elas, além de preparadas e treinadas nas técnicas culinárias, também já haviam recebido noções de cooperativismo e associativismo quando tiveram as aulas ministradas por parte da parceria com a OCB-SESCOOP.

Incialmente foram enfrentados muitos problemas burocráticos em face da 
situação legal das reeducandas, porém com a ajuda da então diretora do presídio, senhora Sandra Regina Monteiro Santos, que se colocou à disposição para representar a cooperativa junto aos órgãos competentes, esta pode finalmente funcionar. A princípio, elas produziam as refeições para algumas internas e para as servidoras da carceragem feminina, depois começaram a fazer os docinhos e salgados para os coquetéis e outros eventos que eram realizados no presídio, na SEJUSC, e também no IFRR.

A parte financeira, a contabilidade, era realizada pela representante legal da cooperativa, que repassava a renda para as reeducandas. Com a renda elas separavam o percentual para a compra dos insumos, que também era realizada pela Diretora, em seguida dividiam o lucro entre si e depois de tudo mandavam o lucro obtido com a venda dos alimentos para ajudar no sustento de suas famílias.

\subsection{MODELO SUSTENTÁVEL}

A partir dos resultados obtidos com a pesquisa realizada entre as reeducandas do presídio feminino do Distrito Federal, apresentamos uma proposta de implantação e estruturação de um programa sustentável para as mulheres privadas de liberdade, reeducandas do Sistema Prisional do Distrito Federal embasado na experiência do Programa Mulheres Mil que foi desenvolvido no Presidio Feminino de Boa Vista Roraima, por meio do Instituto de Educação, Ciência e Tecnologia de Roraima. Espera-se que esse programa tenha sustentabilidade econômica durante o período em que as mulheres se encontrem privadas de sua liberdade, ou seja, que as reeducandas egressas dos cursos ofertados pelo Programa Mulheres Mil no âmbito do sistema prisional do DF, possam ser inseridas no mundo do trabalho, gerar e renda, embora ainda estejam no cumprimento de suas penas sob o regime fechado.

O trabalho da pessoa privada de liberdade, conforme a Lei de Execução Penal, (1993), tem a finalidade educativa e também produtiva. De acordo com esta lei, mesmo que não esteja sujeito ao regime da CLT, o trabalho do reeducando (a) deve ser remunerado, não podendo ser inferior a $3 / 4$ do salário mínimo. Entretanto se as leis trabalhistas não são cumpridas nos presídios, quando se refere à educação, o quadro é ainda mais alarmante, como nos 
aponta ONOFRE, (2014 p.91), o governo não cumpre a lei de garantir a todas as pessoas o direito à educação. [...] na maioria das prisões, porém há uma precária oferta de serviços de formação educacional e profissional.

Sabe-se que a prisão sempre exerceu uma função de recorte das ilegalidades. É para a sociedade, um instrumento de punição e exclusão dos indivíduos. Os projetos que se desenvolvem nos presídios, muitas vezes não apresentam sustentabilidade, existem ali deficiências de toda a natureza, que vão desde o planejamento, condições materiais, espaço físico à falta de efetivo, gerando com isso a descontinuidade dos projetos relacionados à Educação Profissional e geração de renda.

A proposta direcionada ao sistema prisional feminino do DF poderá servir de subsídio para o aporte de política pública a ser fomentada para o Sistema Prisional Feminino do Brasil, em virtude da ausência da execução de uma política pública voltada para este público em particular e com as especificidades que esta população requer. Dados do (INFOPEN/2014), relatam que em junho de 2014, no Brasil, haviam 11.269 mulheres custodiadas no sistema prisional, sem condenação, o que equivale a três em cada dez mulheres presas. Diz ainda que a maior parte das mulheres estava cumprindo pena em regime fechado.

Com relação ao perfil da população prisional feminina brasileira, as reeducandas do DF não divergem das demais que foram apontadas pela pesquisa do INFOPEN, são mulheres que se encontram em situação de vulnerabilidade social, com baixa escolaridade, negras, com três ou mais filhos. Os dados apresentados abrangem diferentes aspectos desde o motivo da prisão ao tipo de regime na qual a presa se encontra.

Esse conjunto de dados reflete dimensões bastante distintas, que
permitem o cruzamento entre si e a elaboração de diagnósticos sobre
as eventuais falhas do sistema de justiça criminal e também de
políticas públicas, que poderiam ser traduzidas em maiores
oportunidades sociais e perfis específicos de mulheres.
(INFOPEN/2014, p. 20. Departamento Penitenciário Nacional)

Observou-se que as reeducandas, beneficiadas pelo Programa Mulheres Mil do PFDF têm o perfil etário semelhante as demais mulheres privadas de liberdade, nos dados constatados pelo relatório (INFOPEN/2014), são mulheres 
jovens, com idades que variam entre 18 a 29 anos, em pleno período economicamente produtivo da vida. A maioria dessas mulheres está cumprindo pena por crimes relacionados ao tráfico e a associação para o tráfico de drogas, o que lhes renderá, conforme o artigo 33 da Lei $n^{\circ} 11.343$ de 23 de agosto de 2006, a reclusão de cinco a quinze anos de prisão. Contudo, o tempo médio que elas passam até cumprirem parte da pena e receberem os benefícios do regime semiaberto é de 8 anos.

Ao se analisar a faixa etária das mulheres privadas de liberdade por Unidade da Federação, percebe-se que o perfil etário repete o padrão nacional jovem em quase todos os estados, com a maioria abaixo dos 34 anos, ou seja, em pleno período economicamente ativo da vida (INFOPEN Mulheres, 2015).

De acordo com Onofre (apud SALLA, 1993, p.97) O Brasil tem uma população monstruosa de miseráveis considerados pela ONU em estado de miséria absoluta. [...] não é fácil pensar em reabilitar e ressocializar alguém para uma sociedade extremamente complexa e difícil. Como é que se convence, segundo, Salla (1993), um indivíduo a voltar a ganhar um salário mínimo, como é que se faz para inseri-lo na economia formal se uma atividade ilegal the rende cinco vezes mais do que o que ele (a) ganharia se estivesse no mercado de trabalho?

Apresentamos a proposta de um programa sustentável economicamente às reeducandas do PFDF, considerando que o IFB já possui um vínculo com esta instituição em face das relações estabelecidas quando do desenvolvimento dos dois cursos no interior do presídio. Entretanto espera-se que antes da implantação, sejam verificadas as especificidades que diferenciam o ambiente prisional dos demais lugares onde os outros cursos de qualificação profissional são desenvolvidos.

Pretende-se, entretanto, apontar algumas sugestões para fortalecer esta proposta que vai além de profissionais capacitados para as especificidades prisionais, por exemplo, como formação específica para ministrar aulas à população carcerária, audiência prévia com as reeducandas sobre a pretensão de cursos, pesquisa de demanda local, ambiente propício à realização dos cursos, lanche, material didático, até a: 
- Proposta metodológica diferenciada, definida para o trabalho no sistema prisional;

- Que as horas de estudo sejam contempladas pela Lei de Execuções Penais LEP, assim como as horas de trabalho já são contempladas;

- Discurso único que caracterize o papel da educação como proposta política para o sistema penitenciário;

- Metodologia que contemple o reconhecimento e a avaliação dos saberes prévios;

- Convênios com empresas, previstos em Lei, para a inserção no mercado de trabalho de reeducandas internas que estudam e as do regime semiaberto;

- $\quad$ Convênios com empresas, previstos em Lei, para o estágio remunerado.

- Divulgação no âmbito dos IFs, sobre os cursos realizados nos presídios.

Conforme dados do INFOPEN/Mulheres, (2014), se analisarmos a evolução da taxa de aprisionamento de homens e de mulheres em relação à população nacional desagregada por gênero, é possível afirmar que, se o ritmo de crescimento da população prisional total no Brasil é acelerado e contrapõe as tendências mais recentes dos países que historicamente investiram em políticas de encarceramento em massa, quando olhamos especificamente para a evolução da população de mulheres no sistema prisional esse movimento cada vez mais profundo de encarceramento é ainda mais contundente. Enquanto a taxa total de aprisionamento aumentou 119\% entre 2000 e 2014, a taxa de aprisionamento de mulheres aumentou $460 \%$ no período, saltando de 6,5 mulheres presas para cada 100 mil mulheres em 2000 para 36,4 mulheres em 2014, (INFOPEN/Mulheres, 2015, p.11).

Diante do exposto, dentro da proposta apresentada, há que se primar pela aplicabilidade da LEP no quesito relativo à educação, já que é dever do estado fornecer à pessoa privada de liberdade assistência educacional, como objetivo de prevenir o crime e orientar o retorno à convivência em sociedade. A lei prevê 
ainda que a assistência educacional compreenderá a instrução escolar e a formação profissional dessa pessoa. Esses benefícios à essas pessoas também são previstos no Plano Estratégico de Educação no Âmbito do Sistema Prisional - PEEASP, inseridos no Decreto № 7.626 de 24 de novembro de 2011.

\subsubsection{OPORTUNIDADE DE RESSOCIALIZAÇÃO E GERAÇÃO DE RENDA PARA AS REEDUCANDAS DO PFDF POR MEIO DO PROGRAMA MULHERES MIL.}

A proposta desse programa economicamente sustentável destinado às reeducandas do presídio feminino do DF sucedeu-se em virtude de os dados revelados pela pesquisa realizada comprovarem que as reeducandas, embora qualificadas profissionalmente, não foram inseridas no mercado de trabalho, portanto não geram renda, não atendendo a um dos principais objetivos do programa.

No início de 2014, o Ministério do Desenvolvimento Social e Combate à Fome (MDS), e o MEC firmaram parceria para integrar o Programa Mulheres Mil ao Programa Nacional de Acesso ao Ensino Técnico e Emprego no Âmbito do Plano Brasil Sem Miséria, (PRONATEC/BSM).

Os múltiplos saberes das mulheres, suas histórias, seu aprendizado e sua vivência motivaram a criação do Programa Mulheres Mil, cujo pilar se constitui em potencializar essa bagagem e transformá-la em qualificação profissional e adequada inserção no mundo do trabalho. (Pronatec/BSM, 2014). O Programa Mulheres Mil é desenvolvido nos presídios femininos de muitos estados, como foi citado anteriormente, todavia ainda não se convencionou uma maneira de inserir no mundo do trabalho as reeducandas egressas dos cursos ofertados no sistema prisional que continuam cumprindo pena. Aquelas que saem em regime semiaberto, ou por cumprimento de pena, "talvez" consigam desenvolver a qualificação que receberam, talvez, porque para elas também não existam registro de dados que se possam comprovar.

O trabalho de uma reeducanda é valorizado por duas perspectivas: porque reduz tempo de cumprimento de sua prisão e porque ajuda a minimizar e preenche a tristeza e a solidão dos dias vividos no interior de uma prisão. A 
remição é benefício a que o condenado faz jus, desde que, em regra, esteja cumprindo a pena em regime fechado ou semiaberto, reduzindo-se sua pena em razão do trabalho ou do estudo. De acordo com o art.126,§ $1^{\circ}$, da LEP, alterado pela Lei12.433/2011, a contagem de prazo, para fins de remição, será feito da seguinte maneira:

a) 1 (um) dia de pena a cada 12 (doze) horas de frequência escolar (atividade de ensino fundamental, médio, inclusive profissionalizante, ou superior, ou, ainda, de requalificação profissional), divididas, no mínimo, em 3 (três) dias;

b) 1 (um) dia de pena a cada 3 (três) dias de trabalho, cuja jornada deverá ser de 6 (seis) a 8 (oito) horas diárias. (LEP (Lei 7.210/84).

Mesmo sem receber remuneração, algumas reeducandas do Colméia executam variadas atividades laborais, pois com a execução do trabalho, elas gozam de certos privilégios que as outras que não se predispõem a trabalhar não recebem, como por exemplo, a diminuição de certas imposições determinadas pela administração do presídio concernentes a atividades e horários de alimentação ou banho de sol. Entretanto nos reportamos aqui, especificamente à inexistência de um trabalho remunerado, à geração de renda produzida pelas reeducandas, que ainda não é uma realidade no interior do presídio, mas que poderá ser concebida por meio do cooperativismo e o empreendedorismo. E isso já está assegurado no Plano de Política Nacional de Atenção às Mulheres em Situação de Privação de Liberdade e Egressas do Sistema Prisional do País, que garante o acesso ao trabalho para internas com o desenvolvimento de ações que incluam a formação de redes cooperativas e economia a solidária.

A criação de cooperativas que funcionem no interior do presídio feminino é maneira mais viável de poder ofertar oportunidade de trabalho remunerado para as mulheres presas, todavia é de extrema importância, segundo consta na Metodologia de Acesso, Permanência e Êxito do Programa Mulheres Mil, que os cursos, antes de serem negociados entre os ofertantes e demandantes, estejam alinhados às demandas das realidades das mulheres que irão se beneficiar, e também de seus saberes, ou seja não adiantará ofertar um curso às detentas no qual elas não irão desenvolver as habilidades aprendidas e nem gerar renda. 
O trabalho promove inclusão social, propicia a dignidade e a autoestima, além de proporcionar geração de renda para si e para o sustento de sua família, o trabalho remunerado permitirá que elas vislumbrem uma nova chance para suas vidas, especialmente quando retornarem à sociedade, tenham mais oportunidade de inserção no mercado de trabalho.

A maior angústia das mulheres é igual à dos homens - estar privada de liberdade. Viver entre grades, ter a vida regrada e controlada é uma experiência aterrorizante. Mas, diferente de muitos homens, as mulheres vivem um acréscimo de angústia: os filhos dependem delas ou as acompanham ao presídio. A história mais comum é uma mulher "cair", ou seja, ser presa, após seu companheiro ter sido preso. Assim, a prisão de uma mulher, regra geral, marca um ciclo dramático para a sobrevivência familiar: os filhos dependem dela antes mesmo da entrada no crime e dependerão mais ainda com a prisão do companheiro e dela DINIZ (2015):

Nas atribuições das equipes de trabalho que compõe o Programa Mulheres Mil, constam alguns itens que, se articulados com parcerias externas, favorecerão o desenvolvimento de trabalho, com vistas à geração de renda, pelas reeducandas, ainda no cumprimento de suas penas em regime fechado. Para que se obtenha êxito na realização e no desenvolvimento do programa no âmbito dos presídios femininos os gestores deverão realizar essas parcerias preliminarmente.

\footnotetext{
Sensibilizar e agregar novos parceiros e colaboradores para integrarem o esforço coletivo do Programa, em ação conjunta com as equipes multidisciplinares dos ofertantes; articular, com outras instâncias públicas e privadas, a organização e inserção das mulheres em arranjos produtivos, sociais e culturais e em empreendimentos econômicos solidários (associações, cooperativas, microempreendimentos individuais, entre outros) (PRONATEC/BSM, 2014, p. 7 e 8$)$.
}

Toda ação educativa, deve, portanto, promover o indivíduo, e este deve transformar o mundo em que está inserido, não se tornando um instrumento de ajuste à sociedade. (ONOFRE, 2014, P. 184). 


\section{CONSIDERAÇÕES FINAIS}

Foi em virtude da vivência como professora e gestora do Programa Mulheres Mil, do IFRR, no período de 2009 a 2012 que surgiu a necessidade de realizar uma pesquisa aprofundada sobre a aplicabilidade do programa e os resultados obtidos com mulheres privadas de liberdade. A experiência adquirida com as reeducandas da penitenciária agrícola do Monte Cristo, em Roraima, e a oportunidade de desenvolver a pesquisa com as reeducandas do Presidio Feminino do DF foram os impulsos que levaram à concretização deste estudo.

Inicialmente A pesquisa seria realizada em Roraima, pois tinha o objetivo de verificar as contribuições do programa às reeducandas da penitenciária de Boa Vista-RR, por ser este o primeiro estado a realizar as ações do projeto Mulheres Mil no âmbito dos presídios. Por problemas operacionais e providenciais, (grifo meu), ela foi desenvolvida no Distrito Federal

A pesquisa se propôs a verificar se os cursos de qualificação ofertados pelo IFB-Campus Gama, no âmbito do Programa Mulheres Mil, às reeducandas egressas, contribuíram para alguns aspectos positivos na vida dessas mulheres, partindo do pressuposto de que este programa é uma política inclusiva e diferenciada de outras que visam à profissionalização. Para que a pesquisa fosse viabilizada foi necessário, primeiramente, conhecer estas mulheres, "conviver" durante algum tempo com e entre elas.

O IFB por meio do Programa Mulheres Mil ofertou dois cursos de Formação Inicial e continuada FIC, com carga horária total de 160 horas cada, no Presidio Feminino do DF, popularmente conhecido como "Colméia", sendo o de Estética Feminina- (Trança Afro) oferecido em 2013.2 para vinte e sete reeducandas e o de Recepcionista, ofertado em parceria com o Pronatec/BSM, as outras vinte e sete, todas elas se encontravam internas no regime fechado, conforme pré-requisito em edital.

Não se encontra com facilidade, literaturas com relatos de pesquisas realizadas no interior de presídios, o sistema prisional causa repúdio e medo. Foram muitas as dificuldades enfrentadas para a concretização deste estudo que vão desde a falta de efetivo de carcereiros, a problemas burocráticos. De acordo com a (LEP, 1984), para cada reeducanda entrevistada, há a necessidade de o 
acompanhamento de dois carcereiros. Por isso o convívio com as reeducandas, citado anteriormente, foi possível porque o local era diferenciado de outras pesquisas, e também da necessidade de conversar, ouvi-las, conviver com elas, estar junto a elas no período da aplicação dos questionários, da realização das entrevistas e do grupo focal.

Os dados evidenciados no questionário socioeconômico revelaram que a maioria das reeducandas são casadas, possuem filhos, exerciam profissão remunerada antes de serem presas, e contribuíam na renda familiar, estavam em idade economicamente ativa. Apesar da baixa escolaridade constatada, algumas delas disseram ter ensino médio completo, e duas disseram que estavam cursando o ensino superior quando foram levadas ao presídio.

A análise também comprovou que o programa foi de grande importância para a vida educacional das reeducandas, pois despertou nelas a vontade de continuar seus estudos, mesmo no processo do cumprimento de pena no interior presídio, proporcionou a mudança de itinerários formativos, contribuiu para a melhoria na interação pessoal, no convívio com as outras reeducandas e até com a carceragem. Porém o fator de maior destaque e de consenso entre as participantes, segundo a análise da pesquisa, foi, a melhoria da autoestima, todas elas relataram estar mais felizes após terem participado do programa.

São raros os programas sociais, ou de outra natureza, desenvolvidos nos presídios femininos, os que iniciam, não se tem conhecimento de registros de êxito ou fracasso. Os poucos, dos quais se tem notícia não apresentam sustentabilidade, não tem continuidade e nem incentivo dos órgãos ligados à segurança pública. Muito se fala, porém pouco se faz, (grifo meu).

Falar do sistema prisional, em especial do feminino, desperta interesse ou talvez curiosidade. Contudo, assim como os programas direcionados às reeducandas são raros, raras, também são as visitas no PFDF, em especial no período da realização da pesquisa quase não se percebeu trânsito de pessoas externas nas alas internas. Conforme informações do (INFOPEN/Mulheres, 2015), a maioria das mulheres encarceradas, cumprem pena por tráfico ou associação para o tráfico de drogas, a maioria envolvidas por seus cônjuges, companheiros ou filhos. Contudo elas se veem abandonadas por eles logo que são levadas para o presídio, elas não recebem visitas íntimas, inclusive na PFDF, 
nem existe local destinado a essa prática, em detrimento do complexo penitenciário masculino, para onde são levados seus maridos ou companheiros, e que, segundo elas mesmas informaram, alguns deles já constituíram novas famílias, novos destinos, deixando-as para trás.

Essa realidade que é enfrentada pelas mulheres encarceradas, motivou as egressas, conforme análise das entrevistas, a se sentirem muito felizes e gratas por terem participado dos dois cursos ofertados, onde tiveram a possibilidade de conhecer novas pessoas, pensar em planos diferentes, criar novas expectativas para suas vidas e até mesmo sonhar, sonhar com um mundo diferente do que elas vivem. Por outro lado, os dados do questionário relataram que suas expectativas quanto à qualificação profissional, que é uma das metas principais do programa, não foram totalmente atingidas. Elas relataram não se sentirem capazes para pôr em prática as qualificações recebidas.

Outra das principais metas do Programa Mulheres Mil é o encaminhamento para a inserção no mercado de trabalho, e a geração de renda. Esta meta não foi atingida pelos cursos ofertados pelo IF - Campus Gama no presídio feminino do Distrito Federal, nos anos de 2013 a 2014 . Esses dados foram comprovados por meio dos resultados das análises do grupo focal.

Pode-se constatar também que as reeducandas não tinham conhecimento acerca das metas do programa, e que elas não foram consultadas a respeito de quais cursos gostariam de participar. Contudo ficou comprovado que o Programa Mulheres Mil contribuiu para despertar nessas mulheres o desejo de refazer suas vidas de forma honesta, de trabalhar, produzir renda para auxiliar no sustento da família, e, quando saírem, montarem seu próprio negócio, uma vez que para elas, ainda não há a possibilidade de trabalhar e ser remunerada enquanto se encontram reclusas.

Apesar de essas reeducandas terem recebido seus respectivos certificados de qualificação profissional, não se observou, entre as dezesseis entrevistadas, nenhuma delas envolvidas em atividades laborais remunerada, ou seja, elas não trabalham, não colocam em prática a qualificação recebida nos cursos, com exceção de algumas que realizam trabalhos internos, como limpeza de banheiros, cozinha e distribuição de lanche. Há outras que "trabalham" nas oficinas de tarefas manuais artesanato em geral, algumas, (bem poucas), 
confeccionam lacinhos e adereços para cães, que, segundo informações da coordenadora do núcleo, uma empresa se instalou ali com a finalidade de contribuir com a reinserção profissional das detentas, porém no período da pesquisa não se percebeu movimentação laboral significante. De acordo com a coordenadora, essas internas recebem um percentual por produção, porém não nos foi informado o respectivo valor. Finalmente outras realizam pequenas atividades, apenas com o intuito de passar e preencher o tempo ocioso.

No NUEN foi instalada uma espécie de salão de beleza, por uma empresa local, do ramo de cosméticos, cujo nome não nos foi autorizado a citar, equipado com alguns objetos e utensílios da área de estética capilar, corporal e de manicure. Entretanto não nos foi esclarecido se ali existe remuneração ao trabalho realizado pelas reeducandas.

Todavia há que se primar que a mudança efetiva só ocorrerá se houver adequações, essa mudança terá que ser agregada a uma qualificação profissional que possibilite a elas ingressar no mundo do trabalho enquanto ainda estão cumprindo pena, pois de que adianta qualificar e não pôr em prática?

É necessário que os cursos ofertados às reeducandas tenham uma proposta diferenciada dos demais cursos realizados pelo Programa Mulheres Mil, a começar pela pesquisa com as futuras alunas e a verificação da demanda de mercado, pois essas mulheres, de acordo com os dados da pesquisa, estão em idade produtiva, possuem família, nenhuma delas informou receber auxílio reclusão, elas vislumbram nos cursos de qualificação profissional, uma oportunidade de trabalho e geração de renda.

Deve-se pensar também em uma forma de trabalho e geração de renda para elas enquanto ainda se encontram no regime fechado, pois de acordo com a (LEP/7.210/84, Art. 117), as reeducandas que saem no regime semiaberto deverão, em um prazo de dez dias, começar a trabalhar com registro em Carteira de Trabalho, e/ou o futuro empregador deverá ser responsável pelos atos da reeducanda conforme esclarecimentos abaixo:

As propostas de trabalho externo devem ser protocoladas no Juízo da VEP, para os presos que estejam no regime semiaberto e devem conter, necessariamente: Nome da empresa empregadora, endereço completo, inclusive CEP; nome completo do empregador e número de sua carteira de identidade e CPF; telefones para contato; nome do sentenciado; função a ser exercida pelo sentenciado; horário do trabalho.

Somente é admissível o cumprimento de pena em residência particular se o 
condenado beneficiário do regime aberto, enquadra-se em uma das situações previstas no art. 117, da Lei de Execução Penal. Admite-se o benefício do trabalho externo ao condenado que inicia o cumprimento da pena em regime semiaberto, independentemente do cumprimento de 1/6 da pena, se a situação fática e as condições pessoais do paciente o favorecerem. E para que este benefício se realize é necessário que o potencial empregador agende uma audiência na Vara de Execuções Penais, nessa audiência ele assinará um termo de compromisso se responsabilizando por todos os atos do preso. Deverá apresentar-se portando os documentos pessoais, CNPJ da empresa, alvará de funcionamento e contrato social. Percebe-se que essas exigências da Lei, embora necessárias, dificultam o ingresso de um detento no mercado de trabalho.

As afirmações acima, comprovam as dificuldades que as reeducandas, ao cumprir suas penas, ou parte dela, enfrentam para se reinserirem no mercado de trabalho, muitas delas não conseguem trabalho, ou algum empregador que se responsabilize por elas, e acabam reincidindo ao crime. Com isso perdem o benefício da Lei e retornam ao presídio para iniciar tudo novamente. Contudo não se pode aqui culpar a Lei de Execuções Penais ou a sociedade, quem empregaria uma (ex) reeducanda se não houvesse interesses ou benefícios em comum?

Espera-se que a partir das conclusões obtidas com este estudo, que os Institutos Federais cumpram o que de fato o programa se propõem a fazer desde sua concepção, expansão até os dias atuais, e que haja mais critério na implantação do Programa Mulheres Mil nos presídios, pois ele foi concebido para proporcionar a mulheres em condição de vulnerabilidade social o acesso à educação, à qualificação, ao emprego e à geração de renda, por meio de uma formação profissional e cidadã, e as reeducandas se enquadram nesse perfil de mulheres.

A Rede Federal é composta, desde 2008, por trinta e oito Institutos Federais, distribuídos em todo o Brasil, fazem parte da rede a Universidade Tecnológica do Paraná, o Colégio Pedro Il e dois CEFETs, um no Rio de Janeiro e outro em Minas Gerais. Portanto, espera-se que a partir das conclusões obtidas com este estudo, seja verificado, no momento da implantação do 
programa Mulheres Mil nos presídios, se todas as providências foram tomadas, pois o instituto federal tem como alvo a promoção a justiça social, a equidade, o desenvolvimento sustentável com vistas a inclusão social, e ainda a busca de soluções técnicas e geração de novas tecnologias. Eles devem responder, de forma ágil e eficaz, às demandas crescentes por formação profissional, por difusão de conhecimentos científicos e de suporte aos arranjos produtivos locais. Porém, o que se conclui com a pesquisa realizada para este estudo é que os cursos de Estética Feminina, e o de Recepcionista, ofertados em parceria como Pronatec/BSM, pelo IFB-Campus Gama, não atingiram todas as metas propostas pelo Programa Mulheres Mil. Entretanto, mesmo não atingindo todas as metas, conseguiram exercer uma significante diferença na vida das alunas reeducandas do PFDF, pois inseriu-as em um contexto educacional, e foi capaz de produzir, na vida delas, grandes mudanças. 


\section{REFERÊNCIAS}

ADORNO, A. S. F. A gestão urbana do medo e da insegurança: violência, crime e justiça penal na sociedade brasileira contemporânea. São Paulo, Tese de Doutorado, Universidade de São Paulo. 1996.

BARDIN, L. Análise de Conteúdo. Lisboa, Portugal; Edições 70, LDA, 2009.

BRASIL. Ministério da Educação e Cultura, Ministério do Desenvolvimento Social e Combate à Fome - Cartilha Pronatec Brasil sem Miséria e Mulheres Mil $2014 . \quad$ Disponível em: http://www.mds.gov.br/documentos/cartilha_mulheres_mil\%202014_editado.pdf . Acesso em 20/08/2014.

BRASIL. Cadernos de Estudos Desenvolvimento Social em Debate. - N 24 (2015) -. Brasília, DF Ministério do Desenvolvimento Social e Combate à Fome

BRASIL. IBGE: Censo Demográfico 2010. Rio de Janeiro, 2011f. Disponível em: http://downloads.ibge.gov.br/downloads_estatisticas.htm Acesso: 07 de novembro de 2014.

BRASIL. IBGE- Pesquisa Mensal de Emprego - PME: Mulher no Mercado de Trabalho: Perguntas e Respostas. Disponível em: http://www.ibge.gov.br/home/estatistica/indicadores/trabalhoerendimento/pme_ nova/Mulher_Mercado_Trabalho_Perg_Resp_2012.pdf. Acesso em: 20/10/2014

BRASIL. Ministério da Justiça: INFOPEN/DEPEN - 2012. Disponível em: http://portal.mj.gov.br/data/Pages/MJ887A0EF2ITEMID0174EA9FA2624D3F96 9E091076FD45F5PTBRIE.htm. Acesso em: 20 /09/ 2014.

BRASIL. Ministério da Justiça. Secretaria Nacional de Justiça. Conselho Nacional de Política Criminal e Penitenciária. Censo penitenciário de 1995. Disponível em: http://depen.com Acesso em: 07 nov. 2002.

. Lei de Execução Penal (Lei n 7.210/84).

- Ministério da Justiça - Conselho Nacional de Política Criminal e Penitenciária- Secretaria de Políticas para Mulheres- Grupo de Trabalho Interministerial. (Org.) Documento Basilar para a Elaboração da Portaria Interministerial MJ/SPM $n^{\circ}$ 210/2014.

. Ministério da Justiça. Secretaria Nacional de Justiça. Conselho Nacional de Política Criminal e Penitenciária - Relatório sobre mulheres encarceradas no Brasil. Disponível em: Relatório sobre mulheres encarceradas no Brasil. Disponível

em: 
http://www.asbrad.com.br/conte\%C3\%BAdo/relat\%C3\%B3rio_oea.pdf . Acesso em: em 13 de julho de 2014.

Leia mais: http://jus.com.br/artigos/30504/a-realidade-das-mulheres-presas-nobrasil-violacao-das-normas-penais-e-a-dignidade-humana\#ixzz3Lpanoiqb

Mulheres Mil na Rede Federal - Caminhos da Inclusão. Brasília: mar

2011.Disponível

em: http://mulheresmil.mec.gov.br/index.php?option=com_content\&view=article\&id= 156\&ltemid=152\&lang=br. Acesso em: 29 abril 2014.

Ministério da Educação e cultura. http://mulheresmil.mec.gov.br/index.php?option=com_content\&view=article\&id= 156\&ltemid=152\&lang=br Programa Mulheres Mil: histórico da comunidade. Disponível em: Acesso em: 27 março de 2010.

Ministério da Educação e Cultura. Programa Mulheres Mil: O processo de alfabetização e de letramento, (re) pensando a prática pedagógica. Disponível em:

http://mulheresmil.mec.gov.br/index.php?option=com_content\&view=article\&id= 1339\%3Aroraima\&catid=96\%3Anoticias-inclusao-comeducacao\&ltemid=155\&lang=br Acesso em: 27 março de 2014.

Ministério da Educação e Cultura. Programa Mulheres Mil: o que é. Disponível em: http://mulheresmil.mec.gov.br/index.php?option=com_content\&view=article\&id= 47\&ltemid=53\&lang=br Acesso em: 27 mar. 2010.

Ministério do Trabalho e Emprego - MTE - Portal do Trabalho e Emprego. Disponível em: http://portal.mte.gov.br/imprensa/rais-e-cagedindicam-crescimento-da-participacao-da-mulher-no-mercado-de-trabalho.htm Acesso em 12/10/2014.

. Ministério do Trabalho e Emprego - MTE - Portal do Planalto. Disponível em: http://www.brasil.gov.br/governo/2013/03/cresce-participacaoda-mulher-no-mercado-de-trabalho>. Acesso em: 12/10/2014.

Mulheres mil: do sonho à realidade $=$ Thousand woman; making drems come true = Mile femmes: du revê à lá réalité. Organização: Estela Rosa. Brasília: Ministério da Educação e Cultura; 2011. Disponível em: Acesso em: 27 dez. 2013.

. Secretaria Especial de Políticas para as Mulheres. III Plano Nacional de Políticas para as Mulheres. Brasília: SPM, 2012.

BRUSCHINI, Cristina; LOMBARDI, Maria Rosa. O trabalho da mulher 
brasileira nos primeiros anos da década de noventa. In: ENCONTRO NACIONAL DE ESTUDOS POPULACIONAIS, 10, 1996. Caxambu, MG, Anais..., Belo Horizonte: ABEP, 1996, $4 \mathrm{v}$.

BRUSCHINI, Cristina. Trabalho das Mulheres no Brasil: continuidades e mudanças no período 1985-1995. São Paulo: Fundação Carlos Chagas, 1998 (Textos FCC 17).

CARVALHO, A. C. C. Reintegração de Presos por meio da educação a distância. Brasília: Ed. SER, 2011.

CHAGAS, R. T. A. Prática - Pesquisa - Ensino. Vol. 1 - Número 1. Campinas/São Paulo. Janeiro/fevereiro/março - 2000. Disponível em: http://www.fecap.br/adm_online/art11/anival.htm acesso 02 de outubro de 2014.

CHIZZOTTI, A. Pesquisa em ciências humanas e sociais. $3^{\mathrm{a}}$ ed. Rio de Janeiro: Ed. Vozes, 2010.

CRAVO, A.C. Análise das causas da evasão escolar do curso técnico de informática em uma faculdade de tecnologia de Florianópolis. Revista GUAL, v.5, n.2, p.238-250. 2012.

CRESWELL, W. J. Projeto de Pesquisa: método qualitativo, quantitativo e misto. Porto Alegre: Artmed, 2007, 248p.

CUNHA, Jacqueline Veneroso Alves da. Doutores em Ciências Contábeis da FEA/USP: análise sob a ótica da teoria do capital humano. São Paulo. 2007. Tese (Doutorado em Ciências Contábeis) - Programa de Pós-Graduação em Ciências Contábeis da Faculdade de Economia, Administração e Contabilidade da Universidade de São Paulo (FEA/USP), São Paulo, 2007.

CUSINATO, Ricardo. Espaço da Penitenciária de Araraquara Dissertação (Mestrado em Antropologia Social). Departamento de Arquitetura da faculdade de Filosofia, Letras e Ciências Humanas da Universidade de S. Paulo, São Paulo, 1982.

Debora Diniz http://www.cnj.jus.br/noticias/cnj/79820-antropologa-debora-dinizconta-experiencia-no-presidio-feminino-de-brasilia. Acesso em 15/10/2015

DURKHEIM, Émile. As Regras do Método Sociológico tradução de Pietro Nasseti. $3^{\text {a }}$ ed. São Paulo: Martin Claret. 2003, p. 82-87

FOUCAUT, M. Vigiar e Punir: nascimento da prisão: 41. ed. Petrópolis, RJ: Vozes, 2013.

FREIRE, P. Educação como Prática da Liberdade. $32^{\mathrm{a}}$ ed. Rio de Janeiro: Terra, 1982. 
Pedagogia da autonomia: saberes necessários à prática educativa. $35^{\mathrm{a}}$ ed. São Paulo: Paz e Terra, 2007.

Pedagogia do oprimido. Rio de Janeiro: Paz e Terra, 2005

FRINHANI, Fernanda de Magalhães Dias; SOUZA, Lídio de. Mulheres encarceradas e espaço prisional: uma análise de representações sociais. Revista Psicologia: teoria e prática, n.7, Vitória, 2005

GATTI, B. A. Estudos Quantitativos em Educação. Revista: Educação e Pesquisa. São Paulo. Fundação Carlos Chagas. Vol. 30, n.1, p. 11-30, jan./abr. 2004. Disponível em: http://www.scielo.br/pdf/ep/v30n1/a02v30n1.pdf Acesso em: 05 de outubro de 2014.

GATTI, B. A. Grupo focal na pesquisa em Ciências Sociais e Humanas. Brasília: Editora Líber Livro, 2012.

GIL, A. C. Métodos e técnicas de pesquisa social. 5. ed. São Paulo: Atlas, 1999.

GODOY, A. S. Pesquisa qualitativa: tipos fundamentais. Revista de Administração de Empresas, São Paulo, v. 35, n. 3, p. 20-29, mai/jun, 1995.

GOVERNO DO ESTADO DE RORAIMA. DECRETO N 16.657-E DE 18 DE FEVEREIRO DE 2014.

GOVERNO DO ESTADO DE RORAIMA. Alteração de DECRETO N DECRETO No 17.675-E DE 2 DE OUTUBRO DE 2014.

GIUZMÁN, V. A. equidade de gênero como tema de debate e de políticas públicas. In: Gênero, família e trabalho no Brasil. Rio de Janeiro: Faperj, 2008.

GÜNTHER, H. Pesquisa qualitativa versus pesquisa quantitativa: esta é a questão? Revista Psicologia: Teoria e Pesquisa. Vol. 22, n.2.

HOFLING, E. de M. Estado e políticas (públicas) sociais. Cadernos cedes, ano XXI, n55, novembro/2001).

INSTITUTO FEDERAL DE EDUCAÇÃO, CIÊNCIA E TECNOLOGIA DE RORAIMA/IFRR. Projeto Mulheres Mil Educação, Cidadania, e Desenvolvimento Sustentável. MEC/SETEC. Colleges - canadense/2006. Brasil - Canadá.

Projeto Inclusão com Educação. Boa Vista-RR, 2007. Educação com Inclusão- Subprojeto IFRR: http://mulheresmil.mec.gov.br/noticias-61940/1400roraima-65118519 - acesso em 14 de maio de 2014. 
INSTITUTO FEDERAL DE EDUCAÇÃO, CIÊNCIA E TECNOLOGIA DE SANTA CATARINA. PRONATEC MULHERES MIL http://www.ifsc.edu.br/campusjoinville/4569-mulheres-mil-proporciona-oportunidades-para-reeducandas-dopresidio-regional-de-joinville. Acessado em: 29/11/2015

LOURO, G. L. Gênero, História e Educação: Construção e Desconstrução In: Educação e Realidade, Porto Alegre, v. 20, n 2, p. 101-132, jul./dez.1995

LENGRUBER, Julita. Cemitério dos vivos: análise sociológica de uma prisão para mulheres. Rio de Janeiro: Achiamé, 1983.

LIMA, El aça Mendonça. Origens da Prisão Feminina no Rio de Janeiro: $O$ Período das Freiras (1942-1955). OAB/RJ, Rio de Janeiro, 1983.

LYNN, L. E. Designing Public Policy: A Casebook on the Role of Policy Analysis. Santa Monica, Calif.: Goodyear. 1980.

LUDKE, Menga \& ANDRÉ, Marli E.D.A. Pesquisa em educação: abordagens qualitativas. São Paulo, Editora Pedagógica e Universitária, 1986. 99p.

KIND, L. Notas para o trabalho com a técnica de grupos focais. Psicologia em revista, Belo Horizonte, v.10, n.15, p.124-36, 2004.

KORMAN, A. K. Self-esteem as a moderator of the congruency between selfperceived aptitudes and vocational choice. Journal of Applied Psychology, 1967. Disponível em: http://www.scielo.br/pdf/rae/v21n3/v21n3a05.pdf. Acesso em 04/12/2015.

MINAYO, C. S. M. Análise qualitativa: teoria, passos e fidedignidade. Revista: Ciência e Saúde Coletiva. Vol.17, n.3. Rio de Janeiro Mar. 2012. Disponível em: http://www.scielo.br/scielo.php?script=sci_arttext\&pid=\$1413812320120003000 07 Acesso em: 03 de outubro de 2014.

MINAYO, C. S. M. (Org). Ciência, Técnica e arte: o desafio da pesquisa social. Pesquisa social: teoria, método e criatividade. Petrópolis: Vozes, 1994. p.9-

MOURA, H, D. A Relação entre a Educação Profissional e a Educação Básica na CONAE 2010: Possibilidades e Limites para a Construção do novo Plano Nacional de Educação. Educ. Soc., v. 31, n. 112, p. 875-894, jul. Set. 2010 887. Campinas. Disponível em http://www.cedes.unicamp.br. Acesso em: 29/09/201429.

NONATO, E. M. N. In Educação de mulheres em situação prisional: experiência que vem do Sul, no processo de reinvenção social. 2010. $213 \mathrm{f}$. Tese (Doutorado em Ciências Sociais) - Programa de Pós-Graduação em Ciências Sociais, Universidade do Vale do Rio dos Sinos, São Leopoldo, 2010. 
OLIVEIRA, L. Os excluídos existem? - Notas sobre a elaboração de um novo conceito. RBCS, n. 33, ano 12 fev. 1997, p. 50 a 117 Disponível em: <http://www.anpocs.org.br/portal/publicacoes/rbcs_00_33/rbcs33_04> Acesso em: 09 nov. 2015.

ONOFRE, E, M, C (Org.) In Espaço da Prisão e Suas Práticas Educativas: Enfoques e Perspectivas Contemporâneas. EduFSCar: São Carlos, 2012.

ONOFRE, E., M, C (Org.) in Educação Escolar Entre as Grades: EduFSCar: São Carlos, 2007.

ONOFRE, E., M, C Educação Escolar na Prisão: O olhar de Alunos e Professores, Jundiaí, Paço Editorial, 2014

OZLAK, O. Políticas Públicas e regimes políticos. Reflexões a partir de algumas experiências latino-americanas. In RAP 16 (1): Jan/marc. Rio de Janeiro 1982, p. $17-60$

PACHECO, Eliezer \& REZENDE, Caetana. Institutos Federais: um futuro por amar. In: CAETANA, J. R. S. (org.) Institutos Federais: comentários e reflexões. Natal: IFRN, 2009. 70p.

PACHECO, E. In Caminhos da Inclusão, Mulheres Mil na Rede Federal. Brasília: SETEC, março de 2011.

PETERS, B. G. "Review: Understanding Governance: Policy Networks, Governance, Reflexivity and Accountability by R. W. Rhodes", Public Administration 76: 408-509. 1998.

RAMOS, Daniela P. Pesquisas de usos do tempo: um instrumento para aferir as desigualdades de gênero. In: BONETTI, A. L.; ABREU, M. A. (org.). Faces da desigualdade de gênero e raça no Brasil. Brasília: Ipea, 2011. p.17-

REVISTA ÂMBITO JURÍDICO $®$ Criminalidade feminina: Estudo do perfil da população carcerária feminina da Penitenciária Professor Ariosvaldo de Campos Pires - Juiz de Fora (MG), 2009. http://www.ambitojuridico.com.br/pdfsGerados/artigos/8444. Acesso em: 04/11/2015.

RIBEIRO, Letícia Érica Gonçalves. A Qualificação Profissional e Cidadã: um Estudo do Programa Mulheres Mil, a partir da Experiência do IFG, Campus de Luziânia. 2013. 160 f. (Dissertação - Mestrado em Educação Profissional) Universidade de Brasília, Brasília, 2013.

RIGOTTO, M. E. A Ignorância Custa um Mundo: O Valor da Educação no Desenvolvimento do Brasil. Capítulo 15. Revista de Administração da PUCRS. Disponível em: 
http://revistaseletronicas.pucrs.br/fo/ojs/index.php/face/article/view/318/255. Acesso em: 17 de outubro de 2014.

ROCHA, L.C. (1994). A prisão dos pobres. Tese (Doutorado). Instituto de Psicologia da Universidade de São Paulo USP. Disponível em: http://www.scielo.br/pdf/pusp/v17n3/v17n3a06.pdf> acesso em: 10 de nov. de 2015.

SALLA, F. A. O Encarceramento em São Paulo: das enxovias à Penitenciária do Estado. 1997. Tese (Doutorado em Sociologia) - Universidade de São Paulo, SP, 1997.

SANTOS, Wanderley G. Cidadania e Justiça. Rio de Janeiro, Campus, 1979.

SOUZA, C. Políticas públicas: Uma revisão da literatura. Bahia: UFB, 2006.

SCHULTZ, T. O capital humano. Rio de Janeiro: Zahar, 1973.

SCOTT, J. W. Gênero: uma Categoria útil para a análise histórica. Traduzido pela SOS: Corpo e Cidadania. Recife, 1990

SUBIRATS, J. El papel de la burocracia en el processo de determinación e implementación de las políticas públicas. Políticas Públicas. Brasília: ENAP, 2006 (Coletânea - Volume 2).

TAVARES, M.S. Com açúcar e sem afeto: a trajetória de vida amorosa de mulheres das classes populares em Aracajú/SE. Serviço Social e Sociedade. São Paulo, $\mathrm{n}^{\circ}$ 101, p.121-145, jan./mar. 2010. Disponível em: http://www.scielo.br/pdf/sssoc/n101/07.pdf Acesso em 10/10/2014

TREVISAN, A, P, e BELLEN, M, H. Avaliação de políticas públicas: uma revisão teórica de um campo em construção. Revista de Administração Pública - RAP - Rio de Janeiro 42(3):529-50, maio/jun. 2008. Acesso em: 14/09/2014 - Disponível em: http://www.scielo.br/pdf/rap/v42n3/a05v42n3.pdf

TURATO, E.R.; Métodos qualitativos e quantitativos na área da saúde: definições, diferenças e seus objetos de pesquisa. Rev. Saúde Pública. v. 39, n.3, p.507-14, 2005.

VIDOR, Alexandre et al. Institutos Federais: antecedentes. In: PACHECO, Eliezer (org.). Os Institutos Federais: Uma revolução na Educação Profissional e Tecnológica. Ed. Moderna, Brasília, 2011. 29/11/2015

WOLFF, M. P. (Coord.). Mulheres e prisão: a experiência do Observatório de Direitos Humanos da Penitenciária Feminina Madre Pelletier. Porto Alegre: Dom Quixote, 2007. 
APÊNDICES 


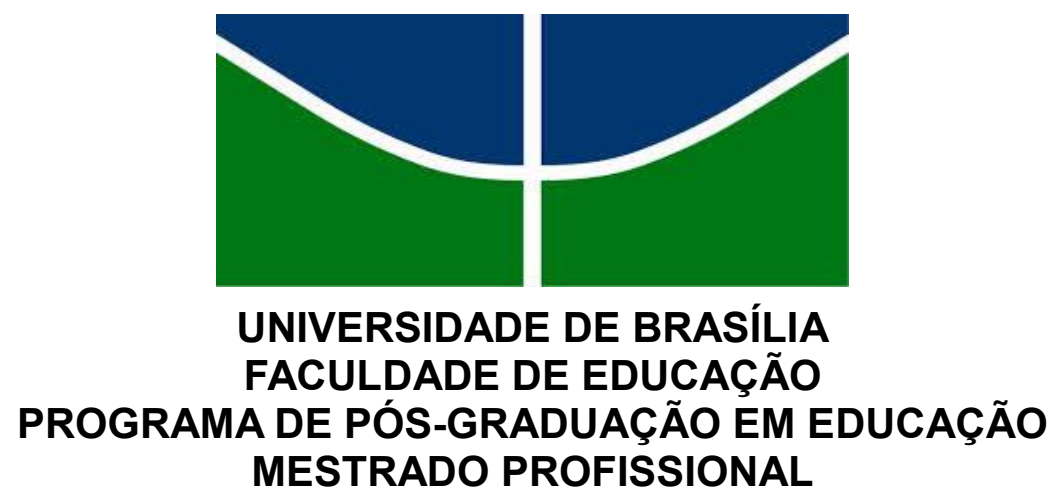

\section{APÊNDICE - A - Autorização do Coordenador do Programa Mulheres Mil no Campus Gama para a realização da pesquisa junto ao Presídio Feminino do Distrito Federal}

Brasília, 08 de abril de 2015.

\section{Ao Professor Sérgio Mariani \\ Coordenador do Programa Mulheres Mil do IFB- Campus Gama}

Sr. Coordenador,

Eu, Crisonéia Nonata de Brito Gomes, Mestranda do Programa de Pósgraduação em Políticas Públicas e Gestão em Educação Profissional e Tecnológica da Universidade de Brasília, solicito, por meio deste, sua autorização para ter acesso aos dados referentes as alunas das duas turmas do Programa Mulheres Mil do Campus Gama, que foi desenvolvido no Presídio Feminino do Distrito Federal.

O estudo que realizarei está sendo orientado pelo Professor Dr. Bernardo Kipnis da UnB, e requer análise de informações contidas no questionário socioeconômico e nos documentos relativos às alunas reeducandas do Programa Mulheres Mil do Campus Gama.

Ressalto que para êxito dessa pesquisa, asseguramos a confidencialidade no tratamento dos dados a serem obtidos, com o compromisso de apenas utilizálos dentro dos objetivos propostos no referido estudo. Minha pesquisa consiste em uma Dissertação de Mestrado cujo título é: Programa Mulheres Mil: Uma oportunidade de Reinserção Social Cidadã às Reeducandas do Presídio Feminino do Distrito Federal.

Com o intuito de preservar os interesses e em respeito aos padrões éticos, as informações e conclusões obtidas nesta pesquisa somente se darão mediante 
prévia autorização das reeducandas. Salientando que ao término, os resultados estarão disponíveis para apreciação e consulta e poderão perfeitamente, ser utilizados como fonte de pesquisa e apoio aos estudos futuros do IFB e a sua contribuição na vida das mulheres privadas de liberdade.

Atenciosamente, 


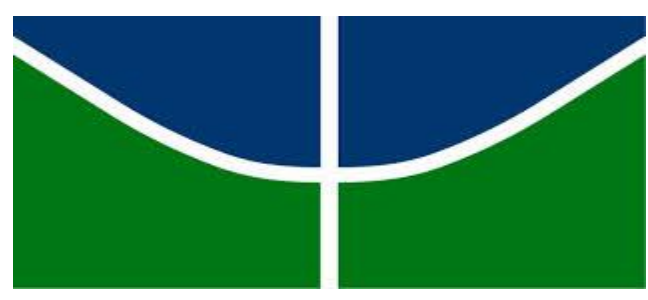

UNIVERSIDADE DE BRASÍLIA

FACULDADE DE EDUCAÇÃO

PROGRAMA DE PÓS-GRADUAÇÃO EM EDUCAÇÃO MESTRADO PROFISSIONAL

\section{APÊNDICE - B - Autorização da Diretora Geral do Campus Gama para a realização da pesquisa junto ao Presídio Feminino do Distrito Federal}

Brasília, 08 de abril de 2015.

\section{À professora Êrika Barretto Fernandes Cruvinel Diretora Geral do Campus Gama}

Sra. Diretora,

Eu, Crisonéia Nonata de Brito Gomes, Mestranda do Programa de Pósgraduação em Políticas Públicas e Gestão em Educação Profissional e Tecnológica da Universidade de Brasília, solicito, por meio deste, sua autorização para ter acesso aos dados referentes as alunas das duas turmas do Programa Mulheres Mil do Campus Gama, que foi desenvolvido no Presídio Feminino do Distrito Federal.

O estudo que realizarei está sendo orientado pelo Professor Dr. Bernardo Kipnis da UnB, e requer análise de informações contidas no questionário socioeconômico e nos documentos relativos às alunas reeducandas do Programa Mulheres Mil do Campus Gama.

Ressalto que para êxito dessa pesquisa, asseguramos a confidencialidade no tratamento dos dados a serem obtidos, com o compromisso de apenas utilizálos dentro dos objetivos propostos no referido estudo. Minha pesquisa consiste em uma Dissertação de Mestrado cujo título é: Programa Mulheres Mil: Uma oportunidade de Reinserção Social cidadã às Reeducandas do Presídio Feminino do Distrito Federal.

Com o intuito de preservar os interesses e em respeito aos padrões éticos, as 
informações e conclusões obtidas nesta pesquisa somente se darão mediante prévia autorização das reeducandas. Salientando que ao término, os resultados estarão disponíveis para apreciação e consulta e poderão perfeitamente, ser utilizados como fonte de pesquisa e apoio aos estudos futuros do IFB e a sua contribuição na vida das mulheres privadas de liberdade.

Atenciosamente, 


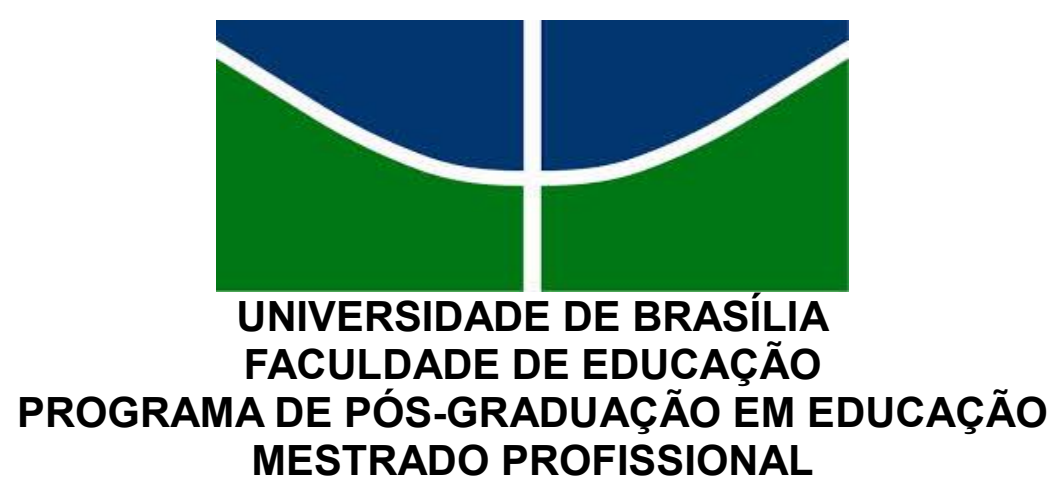

\section{APÊNDICE - C - Termo de Consentimento do Questionário de Pesquisa}

Esta pesquisa se propõe a analisar a contribuição do Programa Mulheres Mil na reinserção social das reeducandas do Presídio Feminino do Distrito Federal, egressas dos Cursos de Estética Feminina e Recepcionista no Instituto Federal de Brasília, Campus Gama. Trata-se de atividade referente ao curso de Mestrado Profissional em Políticas Públicas e Gestão em Educação Profissional e Tecnológica do Programa de pós-graduação da Universidade de Brasília.

Para a realização desta pesquisa, gostaríamos de contar com a sua colaboração, por meio de participação no preenchimento do questionário. Contudo, trata-se de um ato voluntário; você tem total liberdade para abster-se de fornecer as informações solicitadas pelo pesquisador. Neste sentido, pedimos que responda as perguntas da maneira mais coerente e clara possível. Todas as informações são confidenciais e não existem respostas consideradas certas ou erradas. Para a presente pesquisa salienta-se a garantia do anonimato de todas as participantes. Dessa forma, solicitamos sua autorização para apresentar os resultados no estudo acima referido. Caso deseje conhecer os resultados deste trabalho, por favor, contatar a responsável abaixo identificada.

Desde já agradecemos sua colaboração.

\section{Crisonéia N. de Brito Gomes}

Mestranda da Faculdade de Educação - UnB

crisoneia.gomes@ifb.edu.br

Fone: 6183421262

Certifico haver lido o conteúdo acima descrito e compreender que os dados 
serão mantidos em sigilo e que estou participando voluntariamente.

Pelo presente, dou meu consentimento para participar do estudo e para a publicação dos resultados. PFDF - Gama, de de 2014. 


\section{UNIVERSIDADE DE BRASÍLIA \\ FACULDADE DE EDUCAÇÃO \\ PROGRAMA DE PÓS-GRADUAÇÃO EM EDUCAÇÃO \\ MESTRADO PROFISSIONAL}

APÊNDICE - D - Termo de consentimento para participar do Grupo Focal

Declaro que fui satisfatoriamente esclarecido pelo pesquisador (a) Crisonéia Nonata de Brito Gomes, em relação a minha participação no projeto de pesquisa intitulado "PROGRAMA MULHERES MIL: UMA OPORTUNIDADE DE REINSERÇÃO SOCIAL CIDADÃ ÀS REEDUCANDAS DA PENITENCIÁRIA FEMININA DO DISTRITO FEDERAL."

Estou ciente e autorizo a realização dos procedimentos acima citados e a utilização dos dados originados destes procedimentos para fins didáticos e de divulgação em revistas científicas brasileiras ou estrangeiras contanto que seja mantida em sigilo informações relacionada à minha privacidade, além de que se cumpra a legislação em caso de dano. É possível retirar o meu consentimento a qualquer hora e deixar de participar do estudo sem que isso traga qualquer prejuízo à minha pessoa. Desta forma, concordo voluntariamente e dou meu consentimento, sem ter sido submetido a qualquer tipo de pressão ou coação.

Após ter lido e entendido as informações e esclarecido todas as minhas dúvidas referentes a este estudo com pesquisadora Crisonéia Nonata de Brito Gomes, CONCORDO VOLUNTARIAMENTE, participar do mesmo.

Brasília/DF, 20 /02/ 2014

Nome ou assinatura do pesquisado

Desde já agradecemos pela participação na entrevista e nos colocamos a disposição para quaisquer dúvidas e esclarecimento.

Crisonéia N. de Brito Gomes

Crisoneia.gomes@ifb.edu.br 

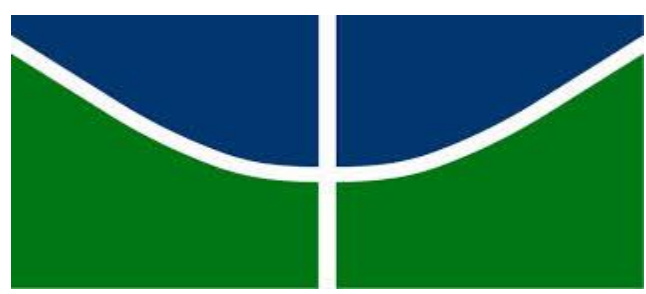

\section{UNIVERSIDADE DE BRASÍLIA \\ FACULDADE DE EDUCAÇÃO \\ PROGRAMA DE PÓS-GRADUAÇÃO EM EDUCAÇÃO MESTRADO PROFISSIONAL}

\section{APÊNDICE - E - Termo de Consentimento para a realização da Entrevista}

Esta pesquisa se propõe a analisar a contribuição do Programa Mulheres Mil na melhoria da qualidade de vida das mulheres egressas das turmas dos Cursos de Estética feminina e Recepcionista formadas pelo Programa Mulheres Mil no Instituto Federal de Brasília - campus Gama, no interior do Presídio Feminino d - Distrito federal, Trata-se de atividade referente ao curso de Mestrado Profissional em Políticas Públicas e Gestão em Educação Profissional e Tecnológica do Programa de pós-graduação da Universidade Brasília. Para a realização desta pesquisa, gostaríamos de contar com a sua colaboração, por meio de participação na entrevista. Contudo, trata-se de um ato voluntário; você tem total liberdade para abster-se de fornecer as informações solicitadas pelo pesquisador ou para encerrar a entrevista a qualquer momento. Neste sentido, pedimos que expresse o que pensa da maneira mais coerente e clara possível. Todas as informações são confidenciais e não existem respostas consideradas certas ou erradas. Para a presente pesquisa salienta-se a garantia do anonimato de todas as participantes. Dessa forma, solicitamos sua autorização para gravar esta entrevista e para apresentar os resultados no estudo acima referido. Caso deseje conhecer os resultados desse trabalho, por favor, contatar a responsável abaixo identificada.

Desde já agradecemos sua colaboração.

\section{Crisonéia N. de Brito Gomes}

Mestranda da Faculdade de Educação - UnB

crisoneia.gomes@ifb.edu.br

Certifico haver lido o conteúdo acima descrito e compreender que os dados 
serão mantidos em sigilo e que estou participando voluntariamente. Pelo presente, dou meu consentimento para participar do estudo e para a publicação dos resultados.

PFDF - Gama, de de 2014.

\section{Assinatura da participante}

Crisonéia N. de Brito Gomes 

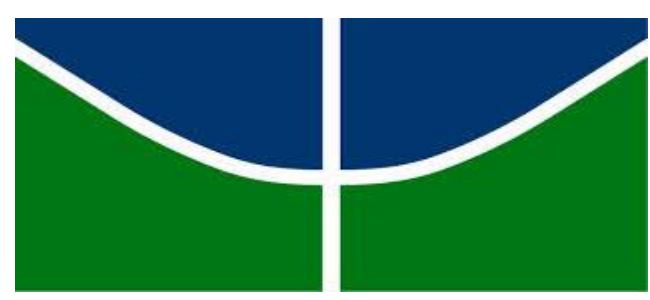

\section{UNIVERSIDADE DE BRASÍLIA \\ FACULDADE DE EDUCAÇÃO \\ PROGRAMA DE PÓS-GRADUAÇÃO EM EDUCAÇÃO MESTRADO PROFISSIONAL}

\section{APÊNDICE - F - Questionário de Pesquisa semiestruturado}

\section{PERFIL}

1. Nome:

2. Idade:

3. Situação Civil: ( ) Solteira ( ) Casada ( ) Divorciada ( ) União Estável ( ) Outra

4. Escolaridade: ( ) Até $4^{\mathrm{a}}$ série ( ) Fundamental Incompleto $\left(5^{\mathrm{a}}\right.$ a $7^{\mathrm{a}}$ série $)($ ) Fundamental Completo ( ) Ensino Médio Incompleto ( ) Ensino Médio Completo ( ) Ensino Superior Incompleto ( ) Ensino Superior Completo

5. Número de Filhos: ( ) Não tem filhos ( ) Até 2 filhos ( ) 3 a 6 filhos ( ) Mais de 6 filhos

6. Estado em que residia antes de vir para o PFDF.

\section{TRABALHO E RENDA}

1. Você trabalhava antes de vir para o PFDF e realizar o curso? Não ( ) Sim ( ) Área de trabalho ou função:

2. Você está trabalhando atualmente? Não ( ) Sim ( ) Área de trabalho ou função: 
3. Qual era a sua participação na Renda Familiar antes de vir para o PFDF? ( ) Não participava na renda familiar ( ) Responsável parcialmente pelo sustento da família ( ) Única responsável pelo sustento da família.

4. Qual a sua participação atualmente? ( ) Não participa na renda familiar ( ) Responsável parcialmente pelo sustento da família ( ) Única responsável pelo sustento da família.

5. A obtenção de um certificado de qualificação profissional contribuiu para o seu ingresso no mercado de trabalho e/ou na melhoria da sua renda familiar mesmo ainda estando cumprindo pena no PFDF? ( ) Não ( ) Diretamente sim - De que forma? ( ) Indiretamente sim - Como?

\section{EDUCAÇÃO}

1. Você estava estudando quando do ingresso no Programa Mulheres Mil?

( )Não ( ) Sim

2. Caso tenha respondido NÃO, você retomou os estudos após ingressar no Programa Mulheres Mil? ( )Não ( ) Sim

3. Caso você tenha respondido SIM, na questão acima, responda: O Programa Mulheres Mil influenciou, de alguma forma, essa decisão? ( ) Não, pois você já pretendia voltar a estudar. ( ) Sim, porque o Programa despertou o desejo em continuar aprendendo. ( ) Outro motivo

\section{IV - SOBRE O PROGRAMA MULHERES MIL}

1. Por que você decidiu se inscrever no Programa? ( ) Para se qualificar e conseguir um trabalho ( ) Para se aperfeiçoar como profissional ( ) Para ter um certificado ( ) Para se socializar ( ) Outro motivo

2. O Programa Mulheres Mil contribuiu de forma positiva na sua vida?

( )Não ( )Sim 
3. Caso tenha respondido SIM, na questão acima, escolha, dentre as opções abaixo, TRÊS contribuições que você considere mais importante. ( ) Elevação da autoestima ( ) Empoderamento ( ). Reconhecer os direitos enquanto cidadã ( ) Conhecimentos sobre Lei Maria da Penha e Direitos da Mulher ( ) Conhecimentos sobre Saúde da Mulher ( ) Reconhecer a importância de cuidar do Meio ambiente ( ) Conhecimentos técnicos (específicos de Recepcionista e Estética Feminina) ( ) Conhecimentos sobre informática e internet ( ) Conhecimentos básicos de português e matemática ( ) Noções de empreendedorismo ( ) Oportunidades de interação social.

4. Os conhecimentos adquiridos na parte técnica do Curso de Estética Feminina e Recepcionista têm sido proveitosos na sua vida diária?

\section{( ) Não ( )Sim}

5. O Programa Mulheres Mil contribuiu para ampliar seus conhecimentos sobre os Direitos da Mulher? ( ) Não, porque o que foi abordado a esse respeito você já conhecia. ( ) Não, porque você não participou das aulas que trataram dessa temática. ( ) Sim, porque os Direitos da Mulher não são muito discutidos normalmente, e o Programa proporcionou essa oportunidade.

6. Em que medida o Programa Mulheres Mil contribuiu para ampliar seus conhecimentos sobre a violência doméstica e os mecanismos de combatê-la?

( ) Contribuiu muito ( ) Contribuiu pouco ( ) Não contribuiu

7. Depois de ter participado do Programa Mulheres Mil, você se sente mais consciente dos seus direitos? ( ) Muito mais consciente ( ) Um pouco mais consciente ( ) Igualmente consciente

8. Quanto à violência contra a mulher, você se sente mais capaz de denunciála? ( ) Muito mais capaz ( ) Um pouco mais capaz ( ) Igualmente capaz ( ) Ainda não se sente capaz 
9. Quais eram as suas expectativas, com relação ao Programa Mulheres Mil, antes de ingressar nele?

10. Os cursos oferecidos pelo Programa Mulheres Mil corresponderam as suas expectativas? ( ) Totalmente ( ) Parcialmente ( ) Não correspondeu 12. Você acredita que o Programa Mulheres Mil, como um todo, contribuiu, de alguma forma para a melhoria da sua qualidade de vida? Justifique sua resposta em algumas palavras.

Muito obrigada por sua contribuição, sem ela, esta pesquisa não seria possível. 


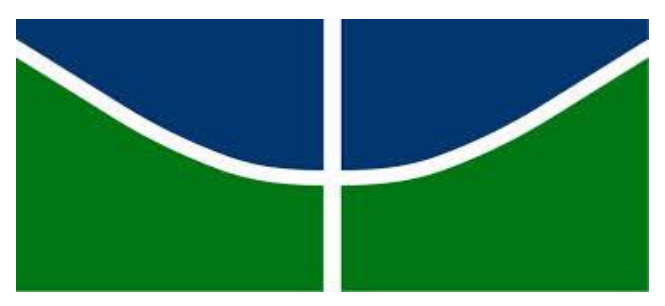

\section{UNIVERSIDADE DE BRASÍLIA \\ FACULDADE DE EDUCAÇÃO \\ PROGRAMA DE PÓS-GRADUAÇÃO EM EDUCAÇÃO \\ MESTRADO PROFISSIONAL}

\section{APÊNDICE - G - Questionário Socioeconômico}

1. Nome:

2. Local:

3. Qual sua idade?

4. Qual seu estado civil?

5. Você trabalhava antes de vir para o presídio? Sim ( ) não ( )

6. De que raça você se considera ( ) Branca ( ) Negra ( ) Parda ( )

Outra

7. Você tem filhos? Sim ( ). Quantos? Não ( )

9. Quantos membros da sua família moravam com você antes? ( ) 1 ( ) 2 ( ) 3

( ) 4 ( ) 5 ( ) mais de 5

10. Você recebia algum tipo de benefício social do Governo Federal ou

Estadual (exemplos: bolsa-família ou outros?) $\operatorname{Sim}($ )

Qual:

( ) Não

11. Qual seu grau de escolaridade? ( ) ensino fundamental incompleto/até $4^{a}$ série ( ) ensino fundamental completo/até $8^{a}$ série ( ) ensino médio incompleto. ( ) ensino médio completo. ( ) ensino superior incompleto. ( ) ensino superior completo.

12. Você recebe algum tipo de renda atualmente?

( ) Sim Qual?

( ) Não 
13. Qual era a renda mensal da sua família? ( ) não tinha renda mensal ( ) até $R \$ 415,00$ ( ) de $R \$ 416,00$ a $R \$ 623,50$ ( ) de $R \$ 623,51$ a $R \$ 1000,00$ ( ) de $R \$ 1010,00$ a $R \$ 2000,00$ ( ) Mais de $R \$ 2000,00$

14. Qual era a sua participação na renda familiar? ( ) Não trabalhava e meus gastos eram financiados pela família ( ) Trabalhava e recebia ajuda da família. ( ) Trabalhava e me sustentava. ( ) Trabalhava e contribuía com o sustento da família. ( ) Trabalhava e era a principal responsável pelo sustento da família. 16. Que curso profissionalizante você gostaria de fazer?

17. Por que você gostaria de fazer esse curso?

18. Onde você espera desenvolver a qualificação recebida no Programa Mulheres Mil?

19- Você crer que seria possível trabalhar e gerar renda, ainda estando cumprindo sua pena em regime fechado? ( )Sim não ( ) 


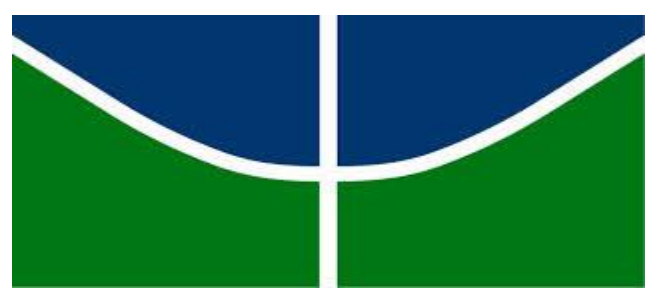

\section{UNIVERSIDADE DE BRASÍLIA \\ FACULDADE DE EDUCAÇÃO \\ PROGRAMA DE PÓS-GRADUAÇÃO EM EDUCAÇÃO MESTRADO PROFISSIONAL}

\section{APÊNDICE - H - Questões Chave para o Grupo Focal}

\section{I - Informações Preliminares às participantes}

- Apresentação

- Agradecimento

- Objetivos do Grupo focal

- $\quad$ Autorização para a gravação da voz

- Tratamento e transcrição dos dados

\section{II - Questões Chave:}

1) O que o Programa Mulheres Mil significou para você?

2) Porque um dos objetivos principais do curso não foi atingido (a geração de renda)?

3) O Programa Mulheres Mil está firmado em 5 princípios: I - Possibilitar o acesso à educação; II - Contribuir para a redução de desigualdades sociais e econômicas de mulheres; III - Promover a inclusão social; IV - Defender a igualdade de gênero; V - Combater a violência contra a mulher. (MEC, 2011) no caso específico do PFDF, vocês acreditam que esses princípios foram alcançados?

4) O programa despertou o desejo de estudar? 
5) houve interação entre professores e alunas durantes as aulas dos cursos?

\section{III - Fechamento da Entrevista:}

Antes de encerrar esta entrevista, gostaria de saber se você tem alguma dúvida, questão e/ou sugestão? Agradeço a sua disponibilidade e interesse. E estou à sua disposição para outras informações, sugestões e/ou críticas que você queira fazer no transcorrer deste trabalho.

Obrigada. 


\title{
MINISTÉRIO DA EDUCAÇÃO E CULTURA \\ Instituto Federal de Educação, Ciência e Tecnologia de Brasília
}

\section{APÊNDICE - I - Solicitação à Secretaria de Segurança de autorização para Entrevista com Reeducandas}

Brasília-DF, 28 de março de 2015.

\author{
Ao Dr. JOÃO CARLOS COUTO LOSSIO FILHO
}

SIA Trecho 3, lotes 1370/1380

\section{SUBSECRETARIO DO SISTEMA PENITENCIÁRIO - SESIP}

Ilustríssimo Dr. JOÃO CARLOS COUTO LOSSIO FILHO, eu, CRISONÉIA NONATA DE BRITO GOMES, Professora do Instituto Federal, Ciência e Tecnologia de Brasília - IFB, matrícula SIAPE:1558200, CPF: 13704656291, aluna do Curso de Mestrado em Educação Profissional pela Universidade de Brasília - UNB, solicito a autorização para realizar entrevista com 07 (sete) reeducandas do Sistema Prisional Feminino do Distrito Federal, alunas egressas do Curso de Estética Feminina, que foi ofertado pelo Programa Mulheres Mil do IFB no ano de 2013 a 2014. O objetivo desta entrevista é a realização de um Grupo Focal, onde as egressas responderão à questões que expressem o grau de satisfação com o curso, as contribuições para o aprendizado de uma ocupação, novos itinerários formativos de vida e sua reinserção no mundo do trabalho, bem como apontar sugestões de melhorias ou outros cursos a serem ofertados pelo IFB, por meio do Programa Mulheres Mil no Sistema Prisional Feminino. O resultado da entrevista do Grupo Focal, integrará a minha Dissertação de Mestrado que tem como Título: PROGRAMA MULHERES MIL: UMA OPORTUNIDADE DE REINSERÇÃO SOCIAL CIDADÃ ÀS REEDUCANDAS DA PENITENCIÁRIA FEMININA DO DISTRITO FEDERAL.

NESTES TERMOS, PEDE-SE DEFERIMENTO. 


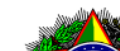 \\ (:०) \\ 굴 \\ MINISTÉRIO DA EDUCAÇÃO E CULTURA \\ Instituto Federal de Educação, Ciência e Tecnologia de Brasília}

\section{APÊNDICE - J - Á Vara de Execuções Penais Solicitação de Autorização para Entrevista com Reeducandas}

Brasília-DF, 28 de março de 2015.

\section{À DOUTORA LEILA CURY}

\section{VARA DE EXECUÇÕES PENAIS - VEP}

SRTVS QD. $701 \mathrm{BI}$. N $08-2^{\circ}$ andar, sala 204/205

Ilustríssima Doutora LEILA CURY, eu, CRISONÉIA NONATA DE BRITO GOMES, Professora do Instituto Federal, Ciência e Tecnologia de Brasília - IFB, matrícula SIAPE:1558200, CPF: 13704656291, aluna do Curso de Mestrado em Educação Profissional pela Universidade de Brasília - UNB, solicito a autorização para realizar entrevista com 07 (sete) reeducandas do Sistema Prisional Feminino do Distrito Federal, alunas egressas do Curso de Estética Feminina, que foi ofertado pelo Programa Mulheres Mil do IFB no ano de 2013 a 2014. O objetivo desta entrevista é a realização de um Grupo Focal, onde as egressas responderão a questões que expressem o grau de satisfação com o curso, as contribuições para o aprendizado de uma ocupação, novos itinerários formativos de vida e sua reinserção no mundo do trabalho, bem como apontar sugestões de melhorias ou outros cursos a serem ofertados pelo IFB, por meio do Programa Mulheres Mil no Sistema Prisional Feminino. O resultado da entrevista do Grupo Focal, integrará a minha Dissertação de Mestrado que tem como Título: PROGRAMA MULHERES MIL: UMA OPORTUNIDADE DE REINSERÇÃO SOCIAL CIDADÃ ÀS REEDUCANDAS DA PENITENCIÁRIA FEMININA DO DISTRITO FEDERAL.

NESTES TERMOS, PEDE-SE DEFERIMENTO. 